\title{
Environmental Surveillance at Hanford for CY-1978
}
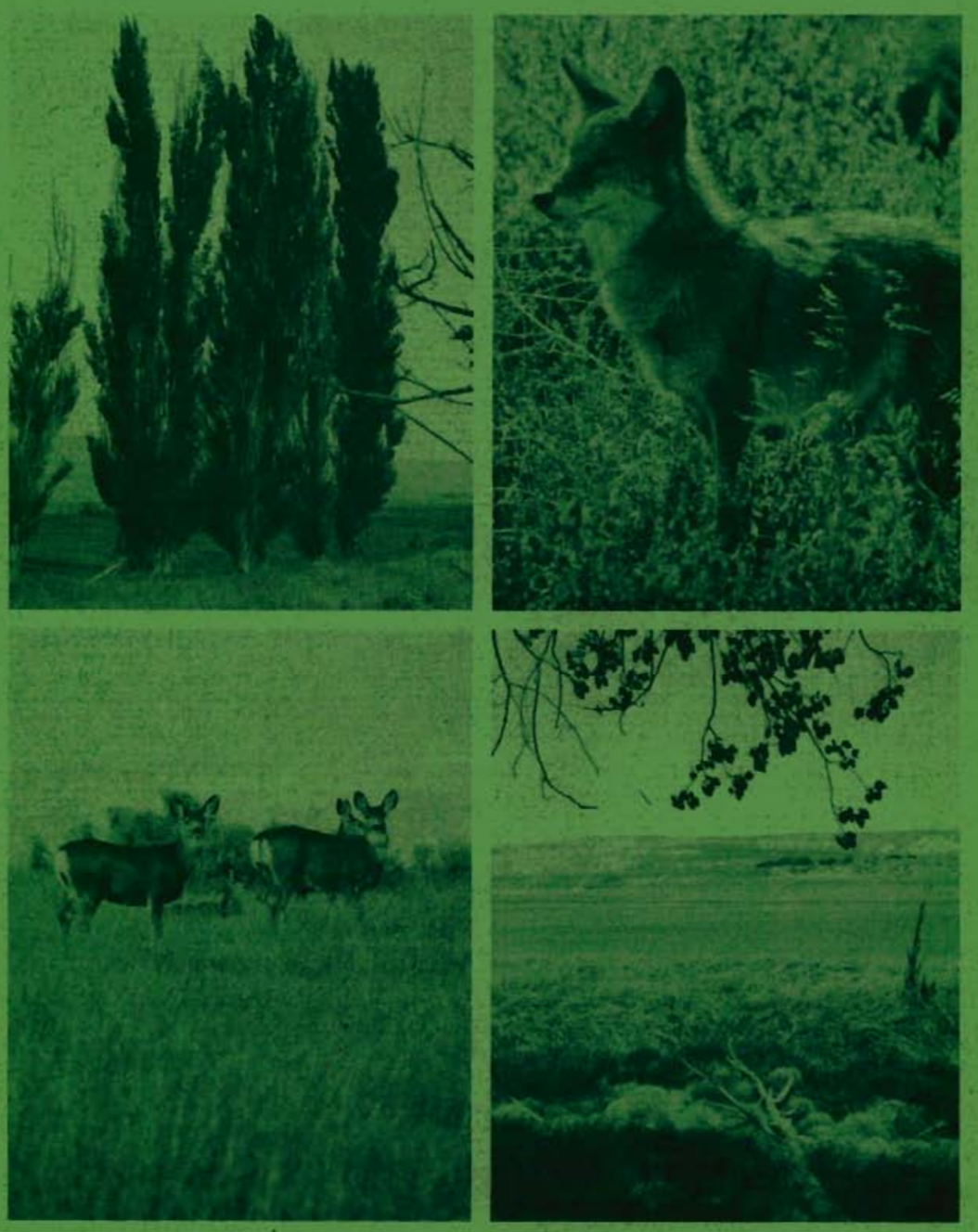

Prepared for the U.S. Department of Energy under Contract EY-76-C-06-1830

Pacific Northwest Laboratory Operated for the U.S. Department of Energy by Battelle Memorial Institute 
NOTICE

This report was prepared as an account of work sponsored by the United States Government. Neither the United States nor the Department of Energy, nor any of their employees, nor any of their contractors, subcontractors, or their employees, makes any warranty, express or implied, or assumes any legal liability or responsibility for the accuracy, completeness or usefulness of any information, apparatus, product or process disclosed, or represents that its use would not infringe privately owned rights.

The views, opinions and conclusions contained in this report are those of the contractor and do not necessarily represent those of the United States Government or the United States Department of Energy.

\author{
PACIFIC NORTHWEST LABORATORY \\ operated by \\ BATTELLE \\ for the \\ UNITED STATES DEPARTMENT OF ENERGY \\ Under Contract EY-76-C-06-1830
}

\begin{tabular}{|c|c|}
\hline \multicolumn{2}{|c|}{$\begin{array}{c}\text { Printed in the United States of America } \\
\text { Available from } \\
\text { National Technical Information Service } \\
\text { United States Department of Commerce } \\
5285 \text { Port Royal Road } \\
\text { Springfield, Virginia } 22151\end{array}$} \\
\hline e: Printed Copy & ; Microfiche $\$ 3.0$ \\
\hline •Pages & $\begin{array}{c}\text { NTIS } \\
\text { Selling Price }\end{array}$ \\
\hline $001-025$ & $\$ 4.00$ \\
\hline $026-050$ & $\$ 4.50$ \\
\hline $051-075$ & $\$ 5.25$ \\
\hline $076-100$ & $\$ 6.00$ \\
\hline $101-125$ & $\$ 6.50$ \\
\hline $126-150$ & $\$ 7.25$ \\
\hline $151-175$ & $\$ 8.00$ \\
\hline $176-200$ & $\$ 9.00$ \\
\hline $201-225$ & $\$ 9.25$ \\
\hline $226-250$ & $\$ 9.50$ \\
\hline $251-275$ & $\$ 10.75$ \\
\hline $276-300$ & $\$ 11.00$ \\
\hline
\end{tabular}


3 3679000531774

ENVIRONMENTAL SURVEILLANCE AT HANFORD FOR CY-1978

J. R. Houston

P. J. Blumer

Apri1 1979

Prepared for

the U.S. Department of Energy

Under Contract EY-76-C-06-1830

Pacific Northwest Laboratory Richland, Washington 99352 


\section{Baltelle}

Pacitic Northwest Laboratories P.O. Box 999

Richland, Washington U.S.A. 99352 Telephone (509)

Telex 15-2874

Ju1y 30, 1979

Recipients of PNL-2932

Dear Recipients:

RE: Environmental Surveillance at Hanford for $\mathrm{CY}-1978$

Pacific Northwest Laboratory, Richland, WA - Apri1 1979.

Please make the following changes in your copy of the subject report:

Page 27 Table 16, Column 3 , enter 5.7 for $133 \mathrm{Xe}$ and $i-$ delete 5.7 for $133 \mathrm{~m} \times \mathrm{e}$

Table 16, Column 5, change 0.23 to 0.12

2

ard change 0.0025 to 0.0013

Table 16, Column 6 , change $14.7 \times 10^{-5}$ to

$4.7 \times 10^{-5}$ and change $7.2 \times 10^{-6}$ to $4.0 \times 10^{-5}$

Page A.2 Table A.3, Column 3 , change $10^{-9}$ to $10^{-12}$

Sincerely,

Yomeo R.Alocetor

James R. Houston

Program Manager

Hanford Environmental Surveillance

Program

$\mathrm{JRH}: \mathrm{mp}$ 


\section{PREFACE}

The Environmental Surveillance Program at the Hanford Site in Washington State is conducted by the Pacific Northwest Laboratory (PNL) under contract to the Department of Energy (DOE). U.S. Government operations at Hanford have always included support for environmental surveillance, and the data collected provide a historical record of the levels of radionuclides and radiation attributable to natural causes, worldwide fallout, and Hanford operations. The findings of the present program demonstrate the negligible impact attributable to either current Hanford operations or cumulative environmental effects from past Hanford operations. Where appropriate, the data are compared with applicable standards for air and water quality set forth by the Department of Energy, the Environmental Protection Agency (EPA), and the state of Washington. Summaries and interpretations of the data are published annually; the present document is for calendar year 1978. 


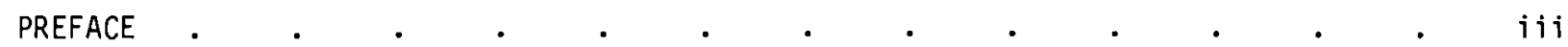

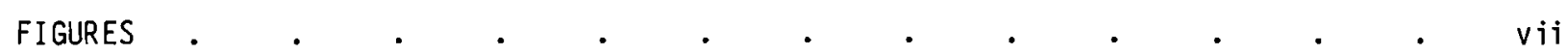

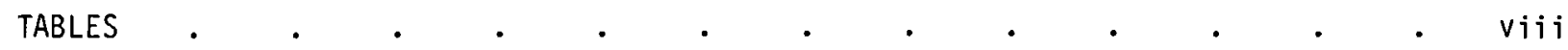

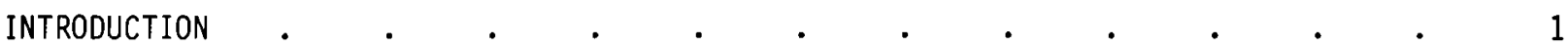

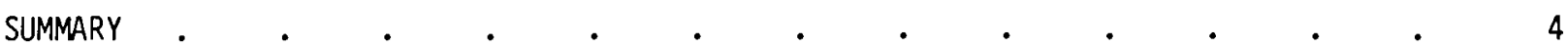

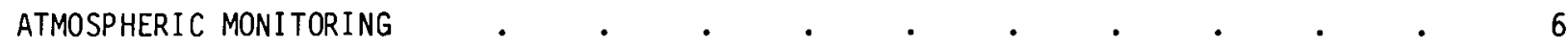

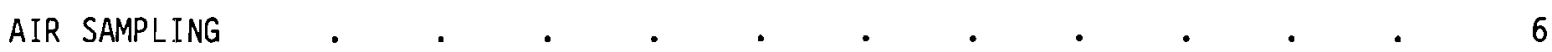

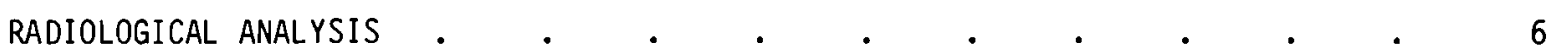

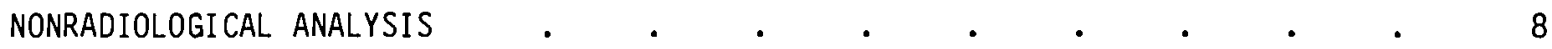

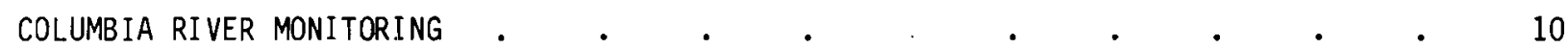

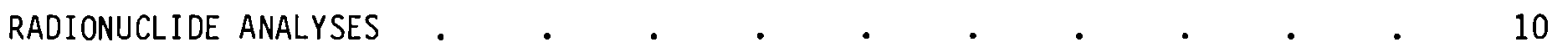

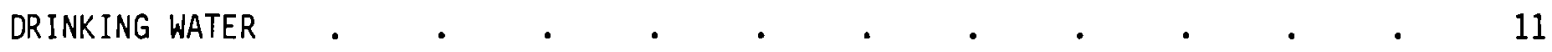

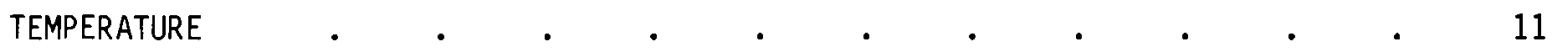

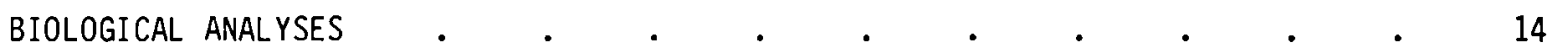

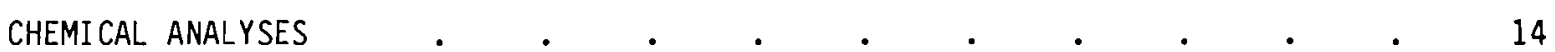

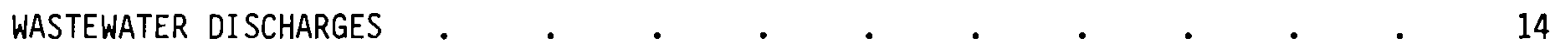

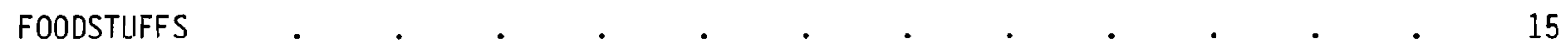

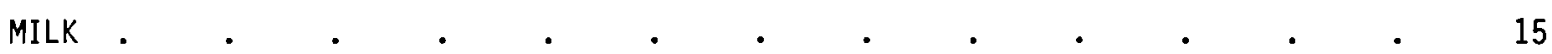

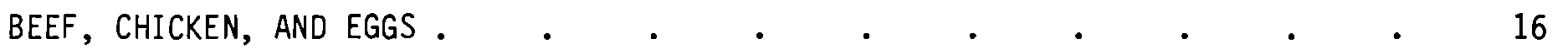

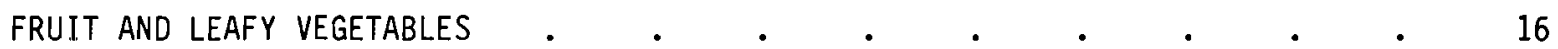

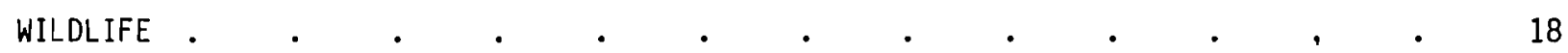

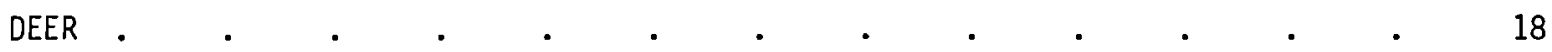

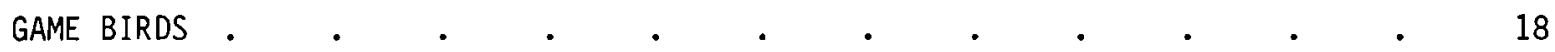

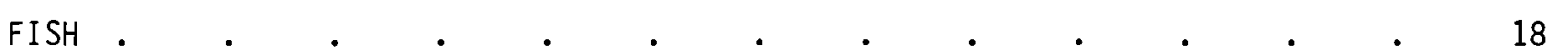

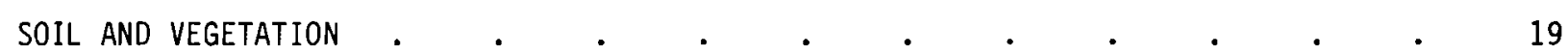

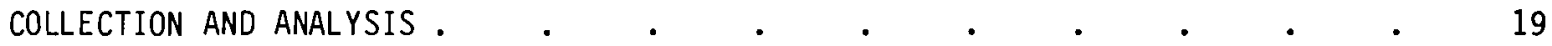

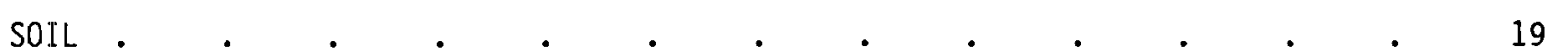

VEGETATION

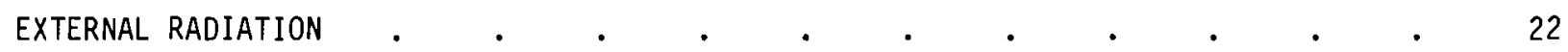

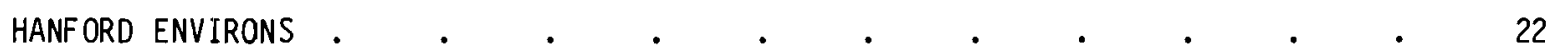




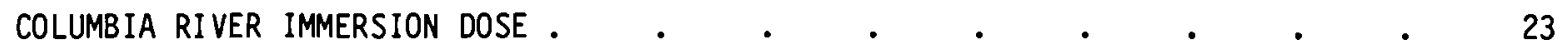

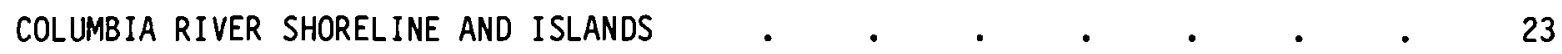

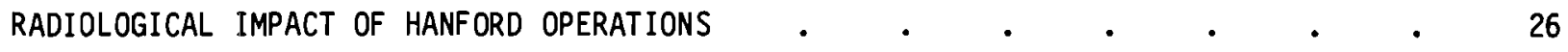

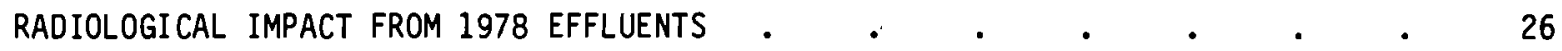

Maximum "Fence-Post" Exposure Rate . . . . . . . . . $\quad 26$

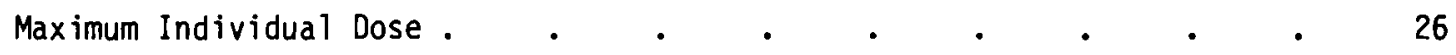

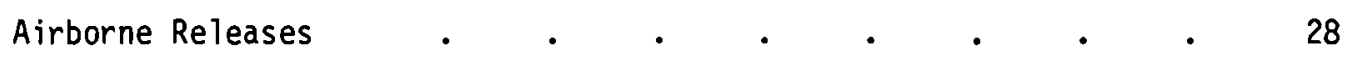

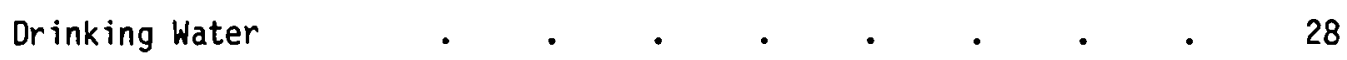

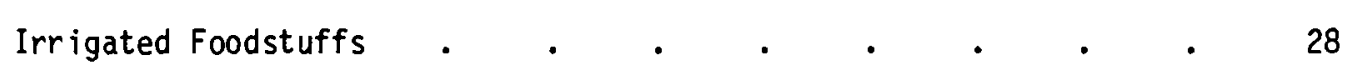

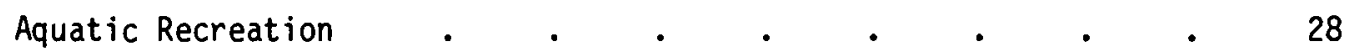

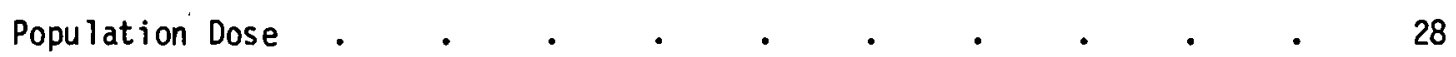

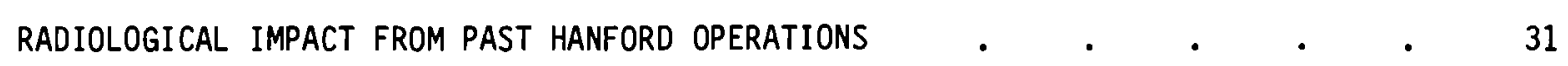

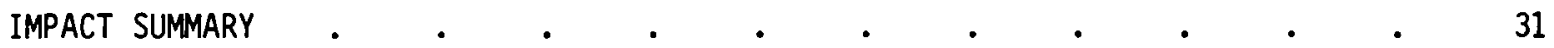

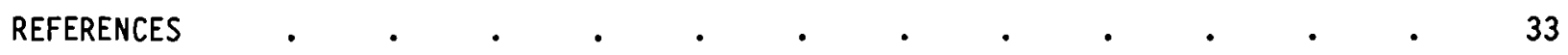

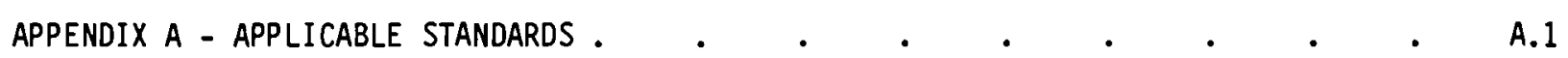

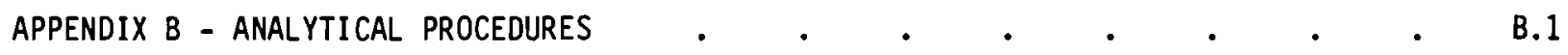

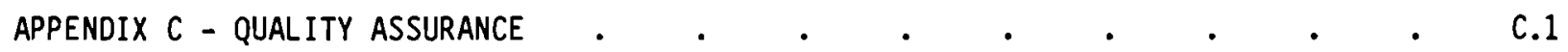

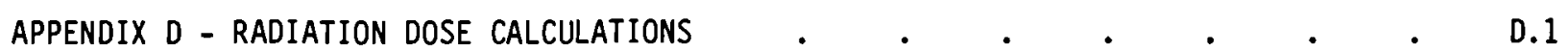




\section{$\underline{\text { FIGURES }}$}

1 DOE's Hanford Site in Washington State $\quad . \quad \ldots \quad$. $\quad . \quad$. $\quad$. $\quad$. 1

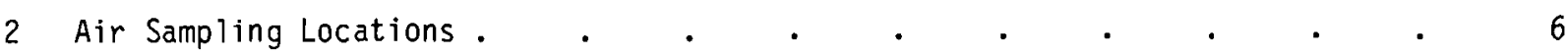

3 Average Monthly Gross Beta Activity in the Atmosphere . . . . 8

4 Upstream and Downstream Concentrations of Radionuclides

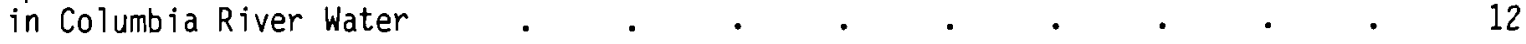

5 Average Monthly Water Temperatures at Richland and Vernita . . . $\quad$ - 13

6 Daily Variation in Mean Temperature and Flow Rate.$\quad$. $\quad . \quad$. 13

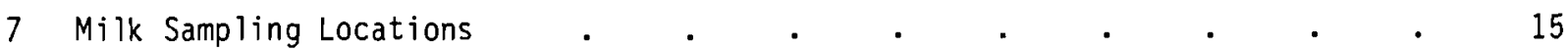

8 Iodine-131 Concentrations in Milk Following March Chinese Test . 16

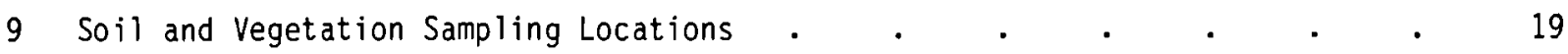

10 Log Normal Probability Plot of Monthly Dose Measurements

11 Thermoluminescent Dosimeter Locations for Columbia River
Immersion and Sediment Measurements $\quad . \quad e$

12 Comparative Doses Received from Various Radiation Sources . . . $\quad$ - 32

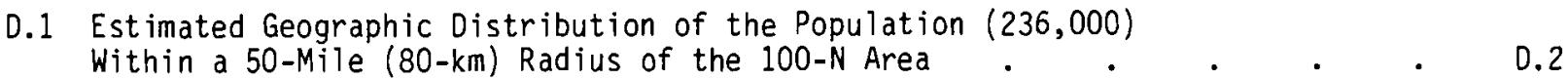

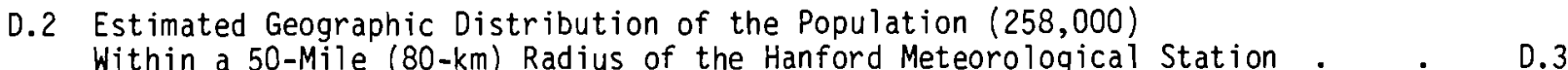

D.3 Estimated Geographic Distribution of the Population $(171,000)$ Within a $50-$ Mile $(80-\mathrm{km})$ Radius of the 300 Areas

D. 4 


\section{TABLES}

1 Airborne Radioactivity in the Hanford Environs . . . . . . . . 7

2 Selected Airborne Radionuclide Concentrations in the Hanford Environs . $\quad 9$

3 Radionuclide Concentrations Upstream from Hanford Operations $\quad$ • $\quad$ • 10

4 Radionuclide Concentrations Downstream from Hanford Operations . $\quad$ • 11

5 Radiological Analyses of Richland Drinking Water . . . . . . . 12

6 Columbia River Chemical and Biological Analyses . . . . . . . . . $\quad$. 14

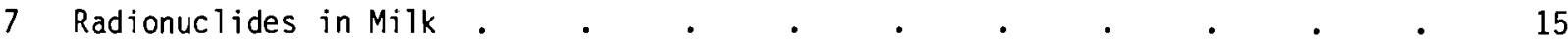

8 Radionuclides in Meat, Chicken, and Eggs . $. \quad \ldots \quad . \quad$. . . . 17

9 Radionuclides in Fruit and Leafy Vegetables . . . . . . . . 17

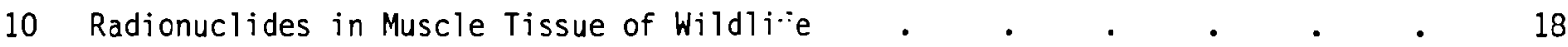

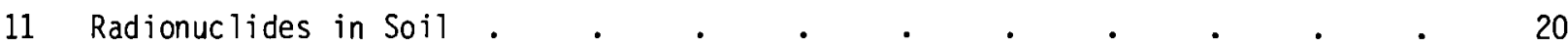

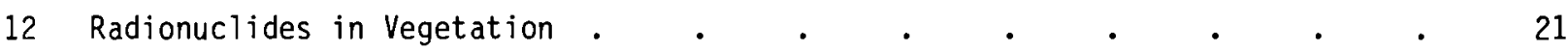

13 Environmental Radiation Dose Measurements in the Hanford Vicinity . . 22

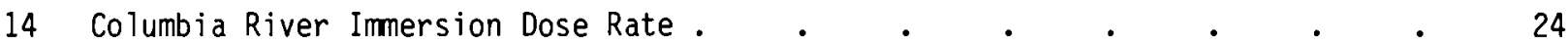

15 Environmental Radiation Dose Measurements Along the Columbia River

16 Radionuclide Composition of Hanford Effluents for Calendar Year 1978 . $\quad 27$

Annual Dose to the Maximum Individual from Effluents Released
During 1978

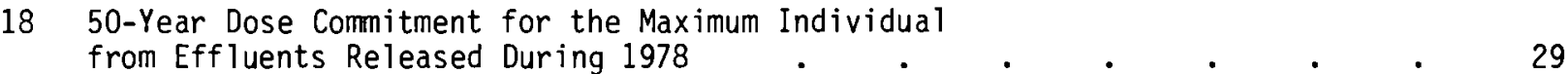

19 Dose to the Population from Liquid Effluents Released During 1978 • $\quad 30$

20 Dose to the Population from Airborne Effluents Released During 1978 . $\quad 30$

A.1 Washington State Water Quality Standards for the Hanford Reach of the Columbia River . . . . . . . . . A.1

A.2 Air Quality Standards . . . . . . . . . . . . . A.2

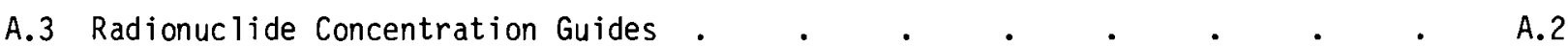

C.1 Summary of Laboratory Intercomparison Results for 1978 . $\quad$ • $\quad$ e $\quad$ e C.2

C.2 QA Data for 100 Area Airborne Release Dose Calculations . . . . . C.4

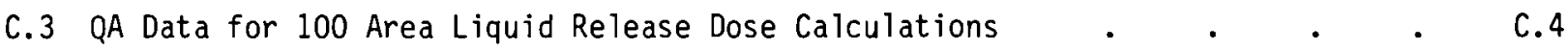

C.4 QA Data for 200 Areas Airborne Release Dose Calculations . . . . . $\quad$ C.5

C.5 QA Data for 300 Area Airborne Release Dose Calculations . . . . . C.5 
D.1 Annual Average Atmospheric Dispersion Around the 100-N Area for an 82-m Release Height . . . . . .

D.2 Annual Average Atmospheric Dispersion Around the 200 Areas for an 89-m Release Height $\quad \cdot \quad \cdot \quad \cdot$

D.3 Annual Average Atmospheric Dispersion Around the 300 Area

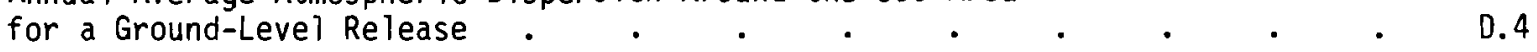

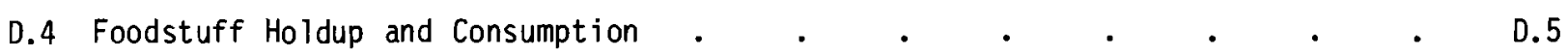

D.5 Consumption and Usage Factors for Calculation of Exposures from the Columbia River 
ENVIRONMENTAL SURVEILLANCE AT

HANFORD FOR CY-1978

\section{INTRODUCTION}

The U.S. Department of Energy's Hanford Site is located in a rural region of southeastern Washington State and occupies an area of $1500 \mathrm{~km}^{2}$ ( 560 square miles). The site, shown in Figure 1 , lies about $320 \mathrm{~km}$ ( $200 \mathrm{miles}$ ) east of Port land, Oregon, $270 \mathrm{~km}$ (170 miles) southeast of Seattle, Washington, and $200 \mathrm{~km}$ (125 miles) southwest of Spokane, Washington. The Columbia River flows through the northern edge of the Hanford Site and forms part of its eastern boundary.

Established in 1943, the Hanford plant was originally designed, built, and operated to produce plutonium for nuclear weapons. At one time, nine production reactors were in operation, including eight with once-through cooling. Between December 1964 and January 1971 , all eight reactors with once-through cooling were deactivated. N Reactor, the remaining production reactor in operation, has a closed primary cooling loop. Steam from $N$ Reactor operation is used to drive turbine generators that produce up to 860 million watts of electrical power in the Washington Public Power Supply System's (WPPSS) Hanford Generating Plant. By the end of 1978, N Reactor had supplied enough steam to produce nearly 45 billion kilowatt hours of electrical energy, which was fed to the Bonneville Power Administration grid covering the Pacific Northwest.

Facilities on the Hanford Site include the historic reactor facilities for plutonium production along the Columbia River, in what are known as the 100 Areas. The reactor fue 1-processing and waste-management facilities are on a plateau about $11.3 \mathrm{~km}$ ( 7 miles) from the river in the 200 Areas. The 300 Area, just north of the city of Richland, contains the reactor fuel manufacturing facilities and research and development laboratories. The Fast Flux Test Facility (FFTF) is located in the 400 Area approximately $3.4 \mathrm{~km}$ (2.1 miles) northwest of the 300 Area.

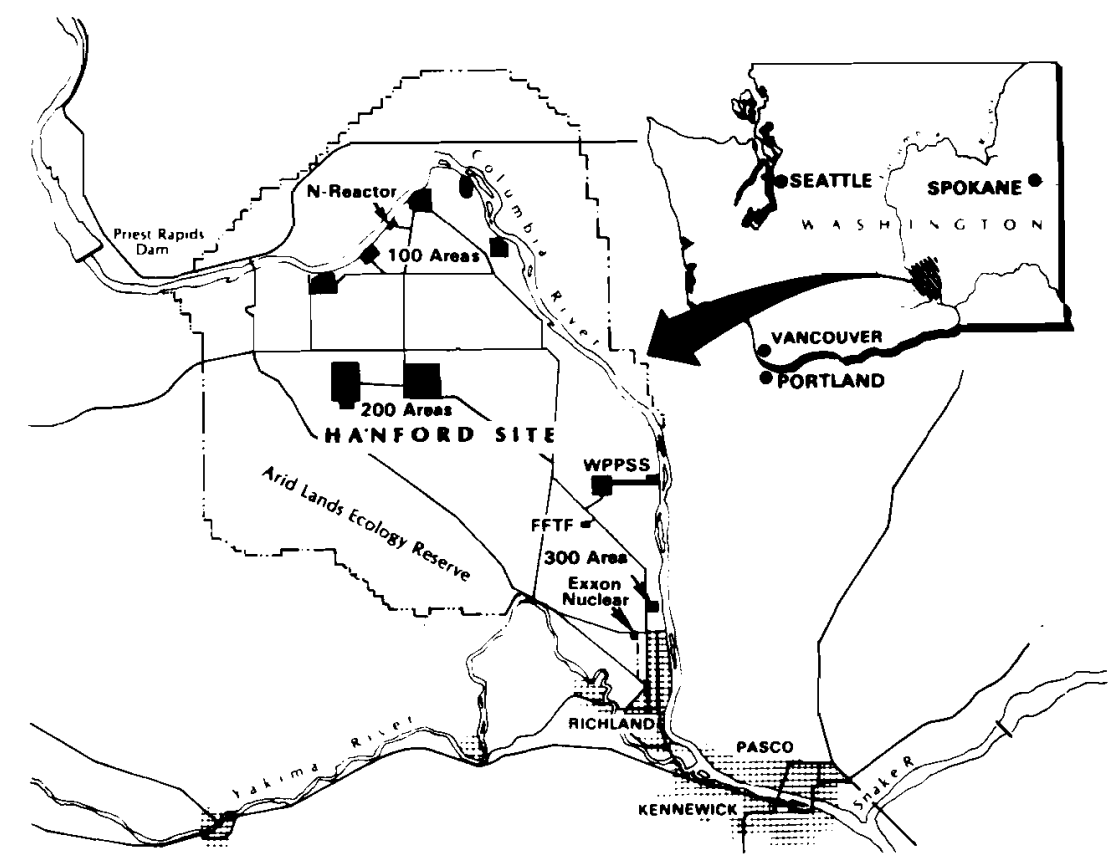

FIGURE 1. DOE's Hanford Site in Washington State 
Privately owned facilities located within the Hanford Site boundaries include the WPPSS generating station adjacent to $\mathrm{N}$ Reactor, the WPPSS power reactor site and office buildings, a hazardous waste disposal site, and a radioactive waste burial site. The Exxon fuel fabrication facility-is located immediately adjacent to the southern boundary of the Hanford Site.

Principal DOE contractors operating at Hanford are:

- Rockwell Hanford Operations (RHO)-responsible for fuel processing, waste management, and all site support services such as plant security, fire protection, central stores, electrical power distribution, etc.

- Battelle Memorial Institute's Pacific Northwest Laboratories--responsible for operating the Pacific Northwest Laboratory (PNL), including research in the physical, life, and environmental sciences, environmental surveillance, and advanced methods of nuc lear waste management.

- UNC Nuclear Industries (UNI)-responsible for operating and fabricating fuel for $\mathrm{N}$ Reactor.

- Westinghouse Hanford Company (WHC)-responsible for operating the Hanford Engineering Development Laboratory (HEDL), including advanced reactor developments, principally the Liquid Metal Fast Breeder Reactor Program and the Fast Flux Test Facility.

During 1978, work at Hanford included N Reactor operation, nuclear fuel fabrication, liquid waste solidification, continued construction of the Fast Flux Test Facility, Hanford National Environmental Research Park (NERP) studies, and Arid Lands Ecology (ALE) studies, as well as continued use of a variety of research and laboratory facilities.

The desert plain on which Hanford is 10cated has a sparse covering of vegetation primarily suited for grazing. The most broadly distributed type of vegetation on the site is the sagebrush/cheatgrass/bluegrass community. The mule deer is the most abundant big game marmal on the site while the most abundant small game animal is the cottontail rabbit. The raccoon is the most abundant furbearing animal. The osprey, golden eagle, and bald eagle are all occasional visitors to the relatively large areas of uninhabited land comprising the Hanford Site.
Hanford's climate is mild and dry; the area receives approximately $16 \mathrm{~cm}$ (6.3 in.) of precipitation annually. About $40 \%$ of the total precipitation occurs during November, December, and January, with on ly $10 \%$ falling in July, August, and September. The average maximum and minimum temperatures in July are $33^{\circ} \mathrm{C}\left(92^{\circ} \mathrm{F}\right)$ and $16^{\circ} \mathrm{C}\left(61^{\circ} \mathrm{F}\right)$. For January, the respective averages are $3^{\circ} \mathrm{C}\left(37^{\circ} \mathrm{F}\right)$ and $-6^{\circ} \mathrm{C}\left(22^{\circ} \mathrm{F}\right)$. Approximately $45 \%$ of all precipitation from December through February is snow.

Mean monthly wind speeds range from about $14 \mathrm{~km} / \mathrm{hr}(9 \mathrm{mph})$ in the surmer to $10 \mathrm{~km} / \mathrm{hr}$ (6 mph) in the winter. The prevailing regional winds are from the northwest, with strong drainage and crosswinds causing complicated surface flow patterns. The region is a typical desert area with frequent strong inversions that occur at night and break during the day, causing unstable and turbulent conditions.

With the exception of Hanford-related industries, the economy of the region is primarily agricultural. Crops include alfalfa, wheat, sugar beets, and potatoes. Several fruit orchards are located within a short distance of the Hanford Site. The Columbia River is used extensively for recreational purposes including fishing.

The population center nearest to the Hanford Site is the Tri-Cities area (Richland, Pasco, and Kennewick), situated on the Columbia River downstream from the site. The three communities, with a combined population of approximately 80,000 , use the Columbia River as a source of drinking water. Approximately 250,000 people live within an $80-\mathrm{km}$ (50-mile) radius of the Hanford Site, in the Yakima area, the Tri-Cities, several small communities, and the surrounding agricultural areas.

The Hanford environmental surveillance program is conducted by PNL under contract to DOE. This program is designed to measure levels of radionuclides and radiation in the Hanford environs and to determine what portions are attributable to natural causes, worldwide fallout, and Hanford operations. The comprehensive ground-water monitoring program, also conducted by PNL for DOE, complements the surface portion of the total program by determining the concentration, distribution, and impact of radionuclide and chemical consfituents and is documented separately. (1) Other environmental data collected deal with certain nonradioactive airborne pollutants and with the chemical and biological quality of the Columbia River and sanitary water. 
All samples are collected according to a master surveillance schedule published each year. (2) The analytical results of these samples are presented and evaluated in a series of annual reports; (3) included in this report are data collected during 1978. Any contribution to air- or waterborne radionuclide concentrations that is attributable to Hanford operations is compared with the regulations in Manual Chapter 0524. (4) Concentrations of nonradioactive pollutants are compared with applicable standards of the state of Washington $(5)$ or the Environmental Protection Agency. (6) 
Environmental data collected during 1978 show continued compliance by Hanford-with all applicable state and federal regulations.

Data were collected for most environmental media including air, Columbia River water, external radiation, foodstuffs (milk, beef, eggs, poultry, and produce) and wildi ife (deer, fish, and game birds), as well as soil and vegetation samples.

In general, offsite levels of radionuclides attributable to Hanford operations during 1978 were indistinguishable from background levels. The data are summarized in the following highlights.

- Hanford operations during 1978 caused no distinguishable impact on concentrations of airborne radionuclides or on external radiation dose measured near to and far from the Hanford Site. (See pages 6-9 and 22-25.)

- Maximum concentrations of airborne radionuclides were observed following the March 15, 1978 atmospheric nuclear test by the People's Republic of China. (See page 7.)

- Concentrations of $131_{\mathrm{I}}$ as high as $8 \mathrm{pCi} / \mathrm{l}$ were observed in milk samples following the Chinese nuclear test in March. The maximum hypothetical dose to an infant thyroid from consumption of milk at the observed levels was about $1 \mathrm{mrem}$. (See pages 15-16.)

- Radionculides observed in foodstuffs, wildlife, and soil samples were all attributed to either worldwide fallout or natural sources. (See pages 15-21.)

- External dosimeter measurements along the Columbia River is lands and shoreline near the Hanford Site showed elevated doses attributed to the presence of a few longlived radionuclides, principally ${ }^{60} \mathrm{Co}$, from past operation of once-throughcooled production reactors. (See pages 22-25.)

- Low-level concentrations of a few radionuclides released to the Columbia River from N Reactor during 1978 were observed at the downstream sampling location. All of the observed river concentrations were far less than $1 \%$ of the most restrictive Manual Chapter guides for unrestricted areas. (See pages 10-11.)
The estimated impact of Hanford operations in terms of radiological dose was computed for both the maximum individual and the population around Hanford. (The maximum individual is a hypothetical person situated so as to receive the maximum radiation exposure possible.) These doses include the impact of measurable levels of radionculides in the environment and those known to have been released but not detectable in the environment. Summarized in the following highlights are the estimated radiological impacts during 1978.

- The maximum "fence-post" exposure rate for $1978,0.075 \mathrm{mR} / \mathrm{hr}$, occurred on the shore of the Columbia River in the vicinity of $N$ Reactor. Slightly contaminated soil along the shoreline is responsible for virtually all of the exposure rate at this point. Discharge of low-level contaminated water from $\mathrm{N}$ Reactor is the cause of this soil contamination. (See page 31.)

- The maximum annual whole-body dose to an individual from 1978 effluents was estimated to be less than $0.1 \mathrm{mrem}$. This included contributions from airborne, drinking-water, irrigated foodstuff, and aquatic recreation pathways. The annual dose to a single organ received from all pathways was less than $0.5 \mathrm{mrem}$ to the thyroid. These doses can be compared with the standards of Manual Chapter 0524 of $500 \mathrm{mrem} / \mathrm{yr}$ for the whole body and $1500 \mathrm{mrem} / \mathrm{yr}$ for organs other than the gonads and the bone marrow. (See pages 26-29.)

- Airborne effluents from the Hanford Site's three operating areas resulted in an annual whole-body dose to the population within an $80-\mathrm{km}$ (50-mile) radius of Hanford of about 1.5 person-rem. Liquid effluents during 1978 contributed very little (about 0.01 person-rem) to the total population dose. This dose estimate may be compared with the approximately 25,000 person-rem received annually from natural background radiation. (See pages 26-32.)

Air quality measurements of $\mathrm{NO}_{2}$ in the vicinity of the Hanford Site and releases of $\mathrm{SO}_{2}$ onsite were well within the applicable federal and state standards. Particulate air concentrations exceed the standards primarily because of agricultural activities in the area. (See page 8.) 
Discharges of waste water from Hanford facilities into the Columbia River under the National Pollution Discharge Elimination
System (NPDES) permit were all within the parameter limits on the permit. (See page 14.) 


\section{ATMOSPHERIC MONITORING}

Many radionuclides from both natural sources and worldwide fallout are present in the atmosphere. Potential contributions to radionuclide levels from Hanford operations are smaller than those already present from worldwide fallout. Air is routinely sampled at numerous locations close to and distant from the Hanford Site to determine the existence and constituents of any Hanford contribution to the airborne radionuclide concentrations. During 1978, no statistically significant difference was observed between radionuclide concentrations at sampling locations near to and distant from the Hanford Site. Hanford contributions were thus indistinguishable from existing regional levels. The maximum airborne radionuclide concentrations were observed in the spring months and are attributed to the March 15, 1978, Chinese nuclear weapons test.

\section{AIR SAMPLING}

During 1978, radionuclides in the atmosphere were sampled by a network of 18 perimeter and 5 distant continuous air samplers at locations shown in Figure 2. Particulate airborne radionuclides are sampled by drawing air at a flow rate of $2.55 \mathrm{~m}^{3} / \mathrm{hr}\left(1.5 \mathrm{ft}^{3} / \mathrm{min}\right)$ through 5-cm (2-in.)-diameter high-efficiency asbestos filter papers. Immediately downstream from the particulate filter is a cartridge of activated coconut charcoal impregnated with potassium iodide for the collection of gaseous radioiodine. Atmospheric moisture, for tritiated water analysis, is collected by passing a portion of the air flow through a cartridge of indicating $\mathrm{si}$ lica gel at a rate of $28.4 \mathrm{l} / \mathrm{hr}(1 \mathrm{ft} 3 / \mathrm{hr})$.

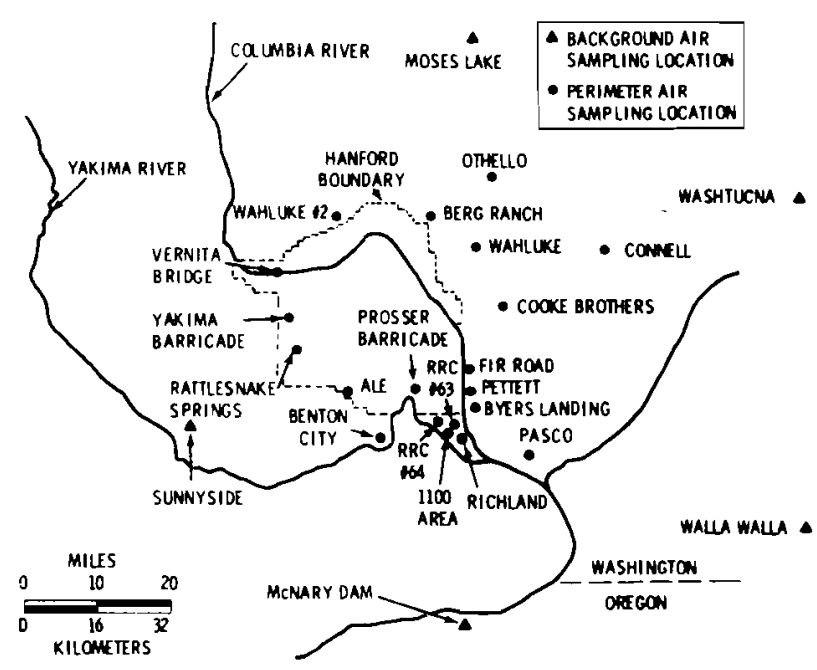

FIGURE 2. Air Sampling Locations
The particulate filters are collected biweekly and analyzed for gross beta and alpha activity after a wait of 7 days to allow the naturally-occurring short-lived radon and thoron daughters to decay. Once a month the filters are grouped by geographical location and analyzed by gamma spectrometry. Each quarter the filters in each geographical group are dissolved and analyzed for $90 \mathrm{Sr}$ and plutonium. Charcoal cartridges from six of the sampling locations are collected and analyzed biweekly for 131 I. If the results of these analyses indicate the need, charcoal cartridges at the remaining stations are analyzed monthly. Otherwise they are just changed monthly. The silica gel cartridges, located at three of the perimeter sampling stations, are collected and analyzed b iweek ly.

\section{RADIOLOGICAL ANALYSIS}

Results for the particulate gross beta, gross alpha and gaseous $131_{1}$ analyses for perimeter and distant sampling stations are shown in Table 1. Gross beta-emitter concentrations during 1978 were essentially the same at all stations, averaging $0.11 \times$ $10^{-12} \mu \mathrm{Ci} / \mathrm{ml}$ for the perimeter stations and $0.10 \times 10^{-12} \mu \mathrm{Ci} / \mathrm{ml}$ for the distant stations. The slight variation between perimeter and distant concentrations is statistically insignificant, indicating no measurable Hanford contribution to the airborne betaemitter concentration. The decrease from the 1977 concentration of $0.19 \times 10^{-12} \mu \mathrm{Ci} / \mathrm{ml}$ for the perimeter stations is attributed to a reduction in worldwide fallout levels. A similar decrease was noted for the average alpha-emitter concentrations. Small concentrations of gaseous 131 I were detected for a short time following the atmospheric 
TABLE 1. Airborne Radioactivity in the Hanford Environs

\begin{tabular}{|c|c|c|c|c|c|c|c|c|c|c|c|c|}
\hline \multirow{4}{*}{$\begin{array}{l}\text { Concentration Guide } \\
\text { Location } \\
\end{array}$} & \multicolumn{12}{|c|}{ Concentration $\left(10^{-12} \mu \mathrm{Ci} / \mathrm{ml}\right)$} \\
\hline & \multicolumn{4}{|c|}{ Gross Beta } & \multicolumn{4}{|c|}{ Gross Alpha $^{(\mathrm{a})}$} & \multicolumn{4}{|c|}{ Iodine-131 } \\
\hline & \multirow{2}{*}{$\begin{array}{r}\text { No. of } \\
\text { Samples } \\
\end{array}$} & \multicolumn{3}{|c|}{100} & \multirow[b]{2}{*}{$\begin{array}{r}\text { No. of } \\
\text { Samples } \\
\end{array}$} & \multicolumn{3}{|c|}{0.03} & \multirow[b]{2}{*}{$\begin{array}{r}\text { No. of } \\
\text { Samples }\end{array}$} & \multicolumn{3}{|c|}{100} \\
\hline & & $\underline{\text { Maximum }}$ & Minimum & Average $^{(c)}$ & & Maximum & $\underline{\text { Minimum }}$ & Average $^{(c)}$ & & Maximum & Minimum & Average $^{(c)}$ \\
\hline \multicolumn{13}{|l|}{ Perimeter Stations } \\
\hline Rattlesnake Springs & 26 & 0.60 & 0.03 & $0.13 \pm 0.24$ & & & & & & & & \\
\hline ALE & 26 & 0.62 & 0.03 & $0.11 \pm 0.23$ & & & & & & & & \\
\hline Benton City & 24 & 0.49 & 0.02 & $0.10 \pm 0.19$ & 23 & 0.003 & $\star$ & $<0.001$ & 25 & $\star$ & $\star$ & $\star$ \\
\hline Yakima Barricade & 25 & 0.65 & 0.03 & $0.10 \pm 0.24$ & & & & & & & & \\
\hline Vernita & 25 & 0.30 & 0.03 & $0.10 \pm 0.11$ & & & & & & & & \\
\hline Wahluke $\# 2$ & 25 & 0.34 & 0.03 & $0.11 \pm 0.16$ & & & & & & & & \\
\hline othello & 26 & 0.44 & 0.04 & $0.11 \pm 0.18$ & & & & & & & & \\
\hline Connell & 26 & 0.56 & 0.03 & $0.12 \pm 0.22$ & & & & & & & & \\
\hline Berg Ranch & 26 & 0.42 & 0.03 & $0.12 \pm 0.20$ & 26 & 0.003 & 0.0006 & $0.001 \pm 0.001$ & & & & \\
\hline Wahluke Watermaster & 26 & 0.33 & 0.03 & $0.10=0.14$ & & & & & & & & \\
\hline Cooke Bros. & 24 & 0.43 & 0.03 & $0.10 \pm 0.17$ & & & & & & & & \\
\hline Richland & 24 & 0.37 & 0.03 & $0.09 \pm 0.14$ & 23 & 0.002 & $\star$ & $<0.001$ & 25 & $\star$ & $\star$ & $\star$ \\
\hline Pasco & 24 & 0.48 & 0.02 & $0.11 \pm 0.20$ & & & & & & & & \\
\hline Byers Landing & 25 & 0.49 & 0.02 & $0.10 \pm 0.19$ & 25 & 0.002 & 0.0007 & $0.001 \pm 0.001$ & 25 & 0.019 & $\star$ & $<0.01$ \\
\hline Pettett Farm & 25 & 0.54 & 0.03 & $0.11 \pm 0.21$ & & & & & 25 & 0.035 & & $<0.01$ \\
\hline Fir Road & 21 & 0.25 & 0.03 & $0.10 \pm 0.12$ & & & & & 23 & $\star$ & $\star$ & $\star$ \\
\hline $\operatorname{RRC} C P \| 64^{(d)}$ & 20 & 0.28 & 0.04 & $0.09 \pm 0.11$ & 20 & 0.003 & 0.0006 & $0.001 \pm 0.001$ & & & & \\
\hline $\operatorname{RRC} C P \sharp 63^{(d)}$ & 6 & 0.46 & 0.08 & $0.17 \pm 0.29$ & 6 & 0.002 & 0.0005 & $0.001 \pm 0.001$ & & & & \\
\hline \multirow[t]{2}{*}{1100 Area } & 26 & 0.40 & 0.04 & $\underline{0.11 \pm 0.15}$ & & & & & & & & . \\
\hline & & & & $0.11 \pm 0.18$ & & & & $<0.001$ & & & & $<0.01$ \\
\hline \multicolumn{13}{|l|}{ Distant Stations } \\
\hline Walla Walla & 26 & 0.46 & 0.04 & $0.11 \pm 0.18$ & & & & & & & & \\
\hline McNary & 26 & 0.20 & 0.03 & $0.09 \pm 0.09$ & & & & & & & & \\
\hline Moses Lake & 24 & 0.20 & 0.03 & $0.09 \pm 0.09$ & & & & & & & & \\
\hline Washtucna & 22 & 0.65 & 0.01 & $0.12 \div 0.27$ & & & & & & & & \\
\hline \multirow[t]{2}{*}{ Sunnys ide } & 23 & 0.27 & 0.03 & $\underline{0.09 \pm 0.12}$ & & & & & 23 & $\star$ & $\star$ & $\star$ \\
\hline & & & & $0.10 \div 0.15$ & & & & & & & & \\
\hline
\end{tabular}

(a) Gross alpha activity does not include any significant contribution due to naturally-occurring radon and short-lived daughters in the air. Filters are held 7 days before analysis to allow radioactive decay of these radionuclides.

(b) Manual Chapter 0524 standards apply only to radionuclide concentrations above those from worldwlde fallout or naturally-occurring radiation.

(c) Average $t$ two standard deviations is shown if all analyses were positive. Otherwise, a less-than-detectable value was calculated from all results, assuming that all less-than-detectable results were equal to the detection $j$ imit for the analysis.

(d) Richland Research Complex control plot.

No entry indicates no analysis.

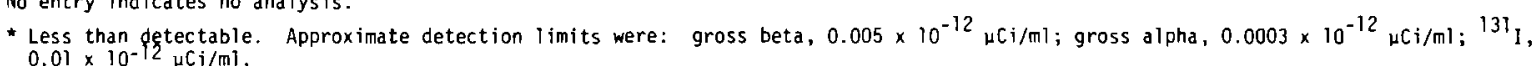

nuclear test by the People's Republic of China in March of 1978.

Gross airborne beta-emitter concentrations for the years 1974 through 1978 are shown in Figure 3. Compared are the average monthly concentrations at perimeter and distant stations in the predominant downwind direction. The increase in airborne radionuclide concentrations observed in the spring is due to an increase in the rate at which natural and nuclear weapons test radioactivity is transferred from the lower stratosphere to the troposphere. This increase was not observed in 1976 or in 1978. The short-term increase in 1978 was due to the Chinese nuclear test in March, when a maximum concentration of
$0.65 \times 10^{-12} \mu \mathrm{Ci} / \mathrm{ml}$ was observed. No increase in airborne beta-emitter concentrations was detected following the December 14 , 1978 nuclear test by China.

Shown in Table 2 are the results of specific radionuclide analyses. Beryllium-7 is a naturally-occurring radionuclide formed by the interaction of cosmic rays and nitrogen in the upper atmosphere. The other radionuclides, with the exception of plutonium, are fission products that result from atmospheric testing of nuclear weapons and, potentially, from Hanford operations.

All of the radionuclides shown were observed at similar concentrations at downwind, distant, and perimeter locations. All 


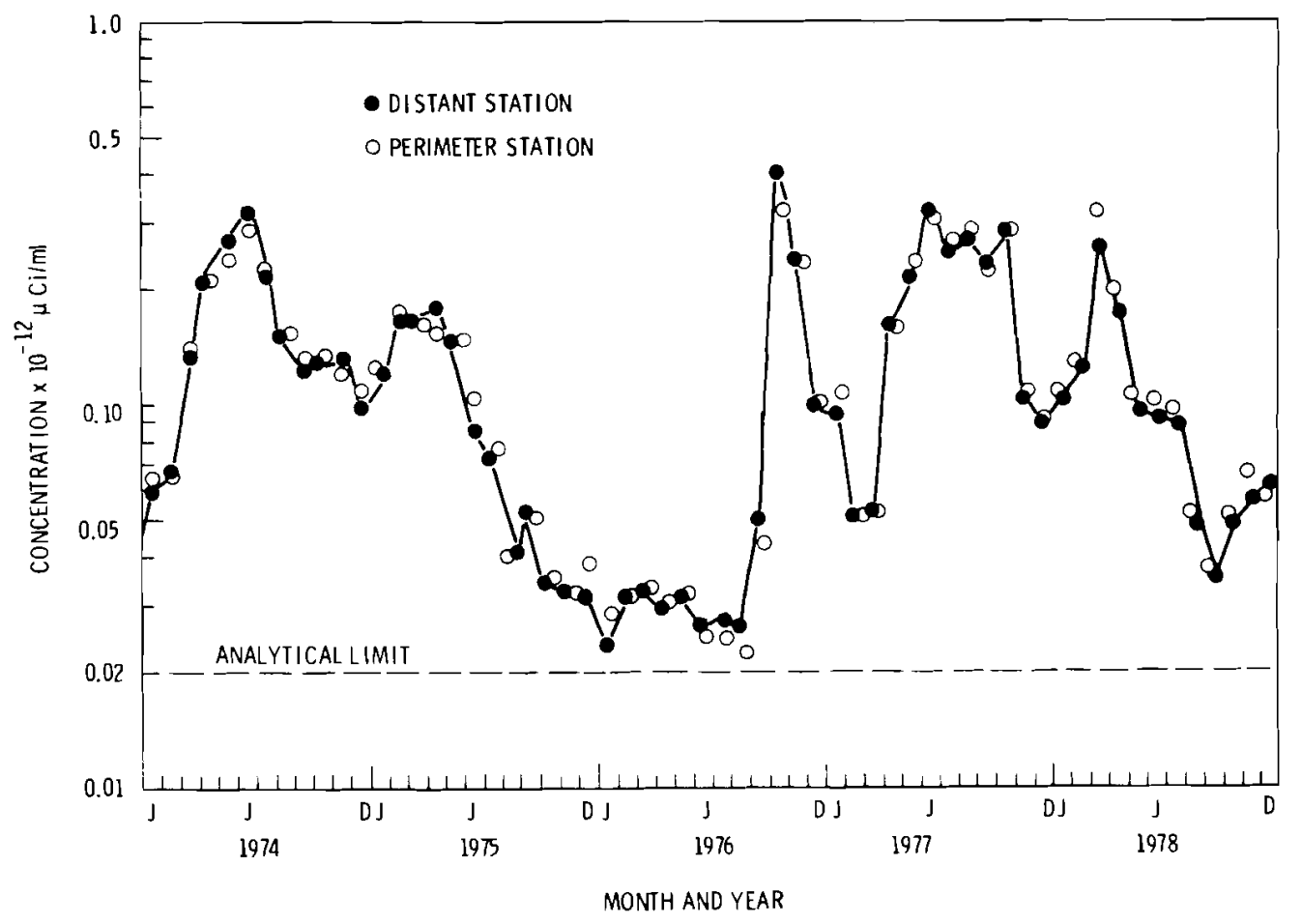

FIGURE 3. Average Month1y Gross Beta Activity in the Atmosphere

of the maximum observed concentrations occurred during the spring months and are attributed to the Chinese nuclear test.

\section{NONRADIOLOGICAL ANALYSIS}

Atmospheric emissions of total suspended particulates (TSP), $\mathrm{SO}_{2}$, and $\mathrm{NO}_{2}$ are within applicable standards except for the TSP emission from two steam power plants. Projects have been defined to bring the TSP emissions within applicable standards.

The Hanford Site and surrounding area are not in compliance with the national and state primary ambient air standards for TSP.I There are several reasons for this, none of which are related to Hanford operations. Primary contributors to the TSP concentrations in this area are agricultural and construction activities. Point source emissions of TSP on the Hanford Site total less than 5000 tons/yr compared to an estimated
$2,500,000$ tons in fugitive dust emissions from the surrounding three-county area.

During the last six months of 1978 , measurements of $\mathrm{NO}_{2}$ concentrations were made by the Hanford Environmental Health Foundation at several locations on the site boundary. An EPA-designated method was used. (7) The maximum 24-hour concentration of $50 \mu \mathrm{g} / \mathrm{m}^{3}$ occurred across the Columbia River from the 300 Area near the Byers Landing sampling station. The maximum long-term average concentration of $\mathrm{NO}_{2}$ occurred at the same location and was $<12 \mu \mathrm{g} / \mathrm{m}^{3}$. These concentrations are well below the applicable national and state ambient air standards of $250 \mathrm{\mu g} / \mathrm{m}^{3}$ and $100 \mathrm{\mu g} / \mathrm{m}^{3}$ for daily average and annual mean, respectively.

None of the emissions of $\mathrm{SO}_{2}$ from the four active steam power plants exceed the state emission standard of $1000 \mathrm{ppm}$. 
TABLE 2. Selected Airborne Radionuclide Concentrations in the Hanford Environs

\begin{tabular}{|c|c|c|c|c|c|}
\hline \multirow[b]{2}{*}{$\underline{\text { Radionuclide }}$} & \multirow[b]{2}{*}{$\begin{array}{l}\text { Manual Chapter } \\
\text { 0524, Table II (a) }\end{array}$} & \multirow[b]{2}{*}{$\begin{array}{l}\text { Composite } \\
\text { Group (b) }\end{array}$} & \multicolumn{3}{|c|}{ Concentration $\left(10^{-12} \mu \mathrm{Ci} / \mathrm{ml}\right)$} \\
\hline & & & $\begin{array}{l}\text { Maximum } \\
\text { Observed }\end{array}$ & $\begin{array}{l}\text { Minimum } \\
\text { Observed }\end{array}$ & $\begin{array}{r}\text { Annual } \\
\text { Average } \\
\end{array}$ \\
\hline $3_{H}$ & 200,000 & $\begin{array}{l}\text { Distant } \\
\text { Perimeter } \\
\text { Downwind }\end{array}$ & $\begin{array}{r}\text { NS } \\
3.5 \\
\text { NS }\end{array}$ & $\begin{array}{r}\text { NS } \\
\star \\
\text { NS }\end{array}$ & $\begin{array}{c}- \\
<0.8 \\
-\end{array}$ \\
\hline${ }^{7} \mathrm{Be}$ & 40,000 & $\begin{array}{l}\text { Distant } \\
\text { Perimeter } \\
\text { Downwind }\end{array}$ & $\begin{array}{l}0.23 \\
0.23 \\
0.20\end{array}$ & * & $\begin{array}{l}<0.04 \\
<0.04 \\
<0.04\end{array}$ \\
\hline${ }^{54} \mathrm{Mn}$ & 1,000 & $\begin{array}{l}\text { Distant } \\
\text { Perimeter } \\
\text { Downwind }\end{array}$ & $\begin{array}{l}0.003 \\
0.004 \\
0.002\end{array}$ & $\begin{array}{l}\star \\
\star \\
\star\end{array}$ & $\begin{array}{l}<0.002 \\
<0.002 \\
<0.002\end{array}$ \\
\hline${ }^{90} \mathrm{Sr}$ & 30 & $\begin{array}{l}\text { Distant } \\
\text { Perimeter } \\
\text { Downwind }\end{array}$ & $\begin{array}{l}0.007 \\
0.006 \\
0.006\end{array}$ & $\begin{array}{l}{ }^{\star} \\
4 \times 10^{-5} \\
4 \times 10^{-5}\end{array}$ & $\begin{array}{ll}< & 0.002 \\
5 & 0.002 \\
5 & 0.002\end{array}$ \\
\hline${ }^{95} \mathrm{ZrNb}$ & 1,000 & $\begin{array}{l}\text { Distant } \\
\text { Perimeter } \\
\text { Downwind }\end{array}$ & $\begin{array}{l}0.65 \\
0.67 \\
0.02\end{array}$ & $\begin{array}{l}\star \\
\star \\
\star\end{array}$ & $\begin{array}{l}<0.02 \\
<0.02 \\
<0.005\end{array}$ \\
\hline${ }^{106} \mathrm{Ru}$ & 200 & $\begin{array}{l}\text { Distant } \\
\text { Perimeter } \\
\text { Downwind }\end{array}$ & $\begin{array}{l}0.46 \\
0.36 \\
0.32\end{array}$ & $\begin{array}{c}\star \\
\star \\
0.02\end{array}$ & $\begin{array}{r}<0.13 \\
<0.13 \\
0.12\end{array}$ \\
\hline${ }^{137} \mathrm{Cs}$ & 500 & $\begin{array}{l}\text { Distant } \\
\text { Perimeter } \\
\text { Downwind }\end{array}$ & $\begin{array}{l}0.008 \\
0.009 \\
0.007\end{array}$ & $\begin{array}{l}\star \\
\star \\
\star\end{array}$ & $\begin{array}{l}<0.003 \\
<0.003 \\
<0.003\end{array}$ \\
\hline${ }^{144} \mathrm{CePr}$ & 200 & $\begin{array}{l}\text { Distant } \\
\text { Perimeter } \\
\text { Downwind }\end{array}$ & $\begin{array}{l}0.07 \\
0.08 \\
0.20\end{array}$ & $\begin{array}{l}\star \\
\star \\
\star\end{array}$ & $\begin{array}{l}<0.03 \\
<0.03 \\
<0.04\end{array}$ \\
\hline $\mathrm{Pu}$ & 0.06 & $\begin{array}{l}\text { Distant } \\
\text { Perimeter } \\
\text { Downwind }\end{array}$ & $5 \times 10^{-5}$ & $4 \times 10^{-7}$ & $3 \times 10^{-5}$ \\
\hline
\end{tabular}

(a) Manual Chapter 0524 standards apply only to radionuclide concentrations above those from worldwide fallout or naturally-occurring radiation.

(b) Distant stations include Moses Lake, Washtucna, Walla Walla, McNary Dam, and Sunnyside. Perimeter stations are Wahluke \#2, Berg Ranch, Othello, Vernita, Wahluke Watermaster, Connel1, Cooke Bros., Yakima Barricade, Rattlesnake Springs, ALE, Benton City, Fir Road, Prosser Barricade, Byers Landing, Pettett, Richland, Pasco, 1100 Area, and RRC CP \#63 and 64. Downwind stations are Fir Road, Prosser Barricade, Byers Landing, Pasco, Richland, Pettett, 1100 Area, and RRC CP \#63 and 64 .

* Less than the detection limit. This limit varies for each analysis because of different air flow volumes, counting times and radionuclide concentrations. Approximate detection limits in units of $10^{-12} \mu \mathrm{Ci} / \mathrm{ml}$ were $7 \mathrm{Be}, 0.02 ; 54 \mathrm{Mn}, 0.002$; $90 \mathrm{Sr}, 0.0002 ; 95 \mathrm{ZrNb}, 0.002 ; 106 \mathrm{Ru}, 0.02 ; 137 \mathrm{Cs}, 0.002 ; 144 \mathrm{CePr}, 0.02 ; \mathrm{Pu}, 0.000001$

NS = No Samples 


\section{COLUMBIA RIVER MONITORING}

The Columbia River from Grand Coulee Dam to the Washington-Oregon border, a stretch that includes the Hanford reach, has been designated $\mathrm{Class} A$ or excellent by the Washington State Department of Ecology. ${ }^{(5)}$ This designation requires that industrial uses of the river be compatiblelwith substantially all water needs including sanitary water, recreation, and wildlife, as indicated in Appendix A. Many measurements of radionuclide concentration, temperature, nitrate ion, $\mathrm{pH}$, turbidity, dissolved oxygen, fecal and total coliform, and biological oxygen demand are routinely conducted upstream and downstream from Hanford to monitor any effects that may be attributable to Hanford operations. The 1978 measurements show that Hanford operations had a minimal impact on the quality of Columbia River water. All parameters monitored were well within state or federal limits both upstream and downstream from the Hanford Site.

\section{RADIONUCLIDE ANALYSES}

Samples of Columbia River water were routinely collected at upstream and downstream locations. Upstream sampling consisted of a continuous filter-resin sampler at Priest Rapids Dam and a cumulative sampling apparatus at the 100-B Area water intake. Downstream sampling consisted of a continuous filter-resin sampler at the 300 Area forebay and a cumulative sampling apparatus at the Rich land sanitary water treatment plant. Analyses for gamma-emitting radionuclides, tritium, strontium-90, iodine-129, tota 1 plutonium, and natural uranium were routinely performed on the samples.

Since shutdown of the last once-throughcooled production reactor in January 1971, radionuclide concentrations attributable to Hanford operations have been generally undetectable in the cumulative Columbia River water samples. Analysis of the filters and resin from the continuous filter-resin sampler provides radionuclide detection limits far below those obtainable from cumulative water sample analysis. To improve this system still further, gamma-emitter analyses were performed using a high resolution GeLi detector after March 1978. This change means sacrificing some sensitivity for certain radionuclides in order to be able to detect others in a complex mixture of radionuclides. All detection limits are still, however, far below the most restrictive Concentration Guides of Manual Chapter 0524.

Shown in Tables 3 and 4 are all radionuclides detected in at least one sample upstream or downstream from the Hanford Site. The column for number of samples includes only samples for which a result was reported. Table 3 summarizes the 1978 concentrations of natural and worldwide fallout radionuclides measured in a stretch of the Columbia River before it reaches the Hanford Site. Table 4 presents analogous data obtained downstream from Hanford.

TABLE 3. Radionuclide Concentrations Upstream from Hanford Operations (a)

\begin{tabular}{|c|c|c|c|c|}
\hline \multirow[b]{2}{*}{ Radionucl ide } & \multirow[b]{2}{*}{$\begin{array}{r}\text { Mo. of } \\
\text { Samples } \\
\end{array}$} & \\
\hline & & $\begin{array}{l}\text { Maximum } \\
\text { Observed }\end{array}$ & $\begin{array}{r}\text { Minimum } \\
\text { Observed } \\
\end{array}$ & $\begin{array}{l}\text { Annual } \\
\text { Average(b) }\end{array}$ \\
\hline \multicolumn{5}{|c|}{ Naturally Occurring } \\
\hline $40 k$ & 7 & 0.94 & 0.41 & $0.64 \pm 0.34$ \\
\hline${ }^{226} \mathrm{Ra}$ & 4 & 0.08 & 0.02 & 0.05 \\
\hline${ }^{228} \mathrm{Ra}$ & 4 & 0.34 & 0.14 & 0.24 \\
\hline U-Nat & 12 & 0.71 & 0.25 & $0.39 \pm 0.28$ \\
\hline \multicolumn{5}{|c|}{ Worldwide Fallout } \\
\hline $3_{\mathrm{H}}$ & 12 & 560 & * & $<360$ \\
\hline${ }^{59} \mathrm{Fe}$ & 17 & 0.014 & * & $<0.05$ \\
\hline${ }^{60} \mathrm{CO}_{0}$ & 19 & 0.31 & * & $<0.034$ \\
\hline${ }^{90_{S r}}$ & 4 & 0.44 & 0.19 & $0.33 \pm 0.10$ \\
\hline${ }^{95} \mathrm{ZnHb}$ & 20 & 0.011 & $\star$ & $<0.031$ \\
\hline${ }^{103} \mathrm{Ru}$ & 18 & $\star$ & $\star$ & $\star$ \\
\hline $106 \mathrm{Ru}$ & 20 & * & $\star$ & * \\
\hline${ }^{125} \mathrm{Sb}$ & 18 & * & * & * \\
\hline 129, & 11 & $2.2 \times 10^{-5}$ & $5.1 \times 10^{-6}$ & $1.2 \times 10^{-5}$ \\
\hline $131_{1}$ & 18 & * & $\star$ & $\star$ \\
\hline${ }^{152} \mathrm{EU}$ & 7 & 0.14 & * & $<0.008$ \\
\hline Pu Total & 4 & $1.7 \times 10^{-4}$ & $\star$ & $<1.3 \times 10^{-4}$ \\
\hline
\end{tabular}

(a) Samples collected at Priest Rapids Oam and 100-B Area forebay.

(b) Annual average $t$ two standard deviations is show if all analyses were positive. 0therwise, a less-than-detectable value was calculated from all results, assuming that all less-than-detectable results were equal to the detection limit for the analysis.

* Less than detectable. 
TABLE 4. Radionuclide Concentrations Downstream from Hanford Operations (a)

\begin{tabular}{|c|c|c|c|c|c|}
\hline Radionuclide & $\begin{array}{l}\text { No. of } \\
\text { Samples }\end{array}$ & \begin{tabular}{l}
\multicolumn{1}{c}{ Concen } \\
Maximum \\
Observed
\end{tabular} & $\begin{array}{l}\text { rations }\left(10^{-}\right. \\
\text {Minimum } \\
\text { Observed } \\
\end{array}$ & $\begin{array}{c}\mu(\mathbf{i} / \mathrm{m} \mathbf{l}) \\
\text { Annua }(\mathrm{b}) \\
\text { Average }\end{array}$ & $\begin{array}{c}\text { Concentration } \\
\text { Guide (c) }\end{array}$ \\
\hline \multicolumn{6}{|c|}{ Naturally Occurring } \\
\hline${ }^{40} k$ & 10 & 1.0 & 0.35 & $0.73 \pm 0.41$ & -- \\
\hline $226 \mathrm{Ra}$ & 4 & 0.06 & $\star$ & $<0.04$ & 30 \\
\hline${ }^{228} \mathrm{Ra}$ & 4 & 0.38 & 0.15 & 0.27 & 7,000 \\
\hline U-Nat & 11 & 0.84 & 0.34 & $0.54 \pm 0.27$ & 20,000 \\
\hline \multicolumn{6}{|c|}{ Artificially Produced } \\
\hline $3_{H}$ & 11 & 950 & * & $<450$ & $3,000,000$ \\
\hline${ }^{59} \mathrm{Fe}$ & 28 & 0.34 & * & $<0.059$ & 50,000 \\
\hline${ }^{60} \mathrm{CO}_{\mathrm{O}}$ & 28 & 0.30 & * & $<0.035$ & 30,000 \\
\hline${ }^{90} \mathrm{Sr}$ & 4 & 1.1 & 0.22 & $0.46=0.43$ & 300 \\
\hline${ }^{95} \mathrm{ZnNb}$ & 28 & 0.36 & * & $<0.06$ & 60,000 \\
\hline${ }^{103} \mathrm{Ru}$ & 28 & 0.23 & * & $<\quad 0.039$ & 80,000 \\
\hline${ }^{106} \mathrm{Ru}$ & 28 & 1.4 & * & $<0.23$ & 10,000 \\
\hline 125 so & 28 & 0.40 & * & $<0.080$ & 100,000 \\
\hline $129^{2}$ & 12 & $1.0 \times 10^{-4}$ & $1.2 \times 10^{-5}$ & $5.8 \times 10^{-5}$ & 60 \\
\hline $131^{1}$ & 14 & 0.26 & * & $<0.067$ & 300 \\
\hline${ }^{152} \mathrm{EU}$ & 12 & 0.008 & * & $<0.010$ & 60,000 \\
\hline Pu Total & 4 & $2.1 \times 10^{-4}$ & $6.8 \times 10^{-5}$ & $1.1 \times 10^{-4}$ & 5,000 \\
\hline
\end{tabular}

(a) Samples collected at 300 Area forebay and City of Richland sanitary intake.

(b) Annual average \pm two standard deviations is shown if all analyses were positive. Otherwise, a less-than-detectable value was calculated from all results, assuming that all less-than-detectable results were equal to the detection 1 imit for the analysis.

(c) Manual Chapter 0524 standards apply only to radionuclide concentrations above those from worldwide fallout or naturally-occurring radiation.

* Less than detectable.

Several radionuclides were observed downstream from the Hanford Site at slightly higher concentrations than were observed upstream. Table 4 also compares the detected radionuclide concentrations with guidelines for the environment presented in Manual Chapter 0524, Table II. In all cases, the observed concentrations are less than $1 \%$ of the guidelines.

Upstream and downstream data for several radionuclides of potential Hanford origin consistently observed in the Columbia River at concentrations greater than $0.001 \mathrm{pCi} / \mathrm{l}$ are shown in Figure 4 . All of the radionuclides shown occur at similar concentrations at both locations and are attributed primarily to worldwide fallout and natural causes.

\section{DRINKING WATER}

Many communities downstream from Hanford obtain their drinking water in whole or in part from the Columbia River. To determine the impact of Hanford operations on radionuclide concentrations in drinking water, cumulative water samples ( $30 \mathrm{ml}$ every 30 minutes) were collected at the Richland sanitary water treatment plant. Richland is the first community downstream from Hanford to obtain its drinking water from the Columbia River. The detection limits for the analyses performed on the drinking water samples are much higher than those for the river samples but are consistent with analytical procedures used and are within the guidelines of the Washington State Water Quality Standards.

During 1978, the only radioactivity detected in the drinking water was gross alpha and gross beta activity, as shown in Table 5 . Washington State Water Quality Standards require that radionuclide concentrations in drinking water not exceed $5 \mathrm{pCi} / \mathrm{l}$ of gross alpha activity and $50 \mathrm{pCi} / \ell$ of gross beta activity with the further stipulation that certain individual radionuclides not exceed $1 / 100$ of the values shown in Column 2, Table II, Appendix A of the Washington State Rules and Regulations for Radiation Protection. (5) To determine compliance with the state standard, the average individual radionuclide concentrations shown in Table 4 can be compared with $1 / 100$ of the Concentration Guide shown, recognizing that, in many cases, the water treatment facility will reduce the radionuclide concentrations below those observed in the river. All radionuclide concentrations are well within the state standard.

\section{TEMPERATURE}

One of the parameters of the Columbia River most likely to be affected by Hanford operations is temperature. Figure 5 shows the average monthly water temperatures measured at Vernita Bridge and at Richland during 1978. Some of the difference between the two locations is due to natural causes while some is attributable to operations on the Hanford Site. (8) Figure 6 illustrates the daily and seasonal variations in river temperature and flow rate during 1978. Gaps in the data in this figure result from equipment malfunctions at midyear and year end. The greatest difference observed occurred during the summer months when $\mathrm{N}$ Reactor was not in operation. Insolation appears to be the major source of heat for the river. Any heat contribution from $N$ Reactor operations would be a small fraction of the seasonal increases attributable to insolation. 


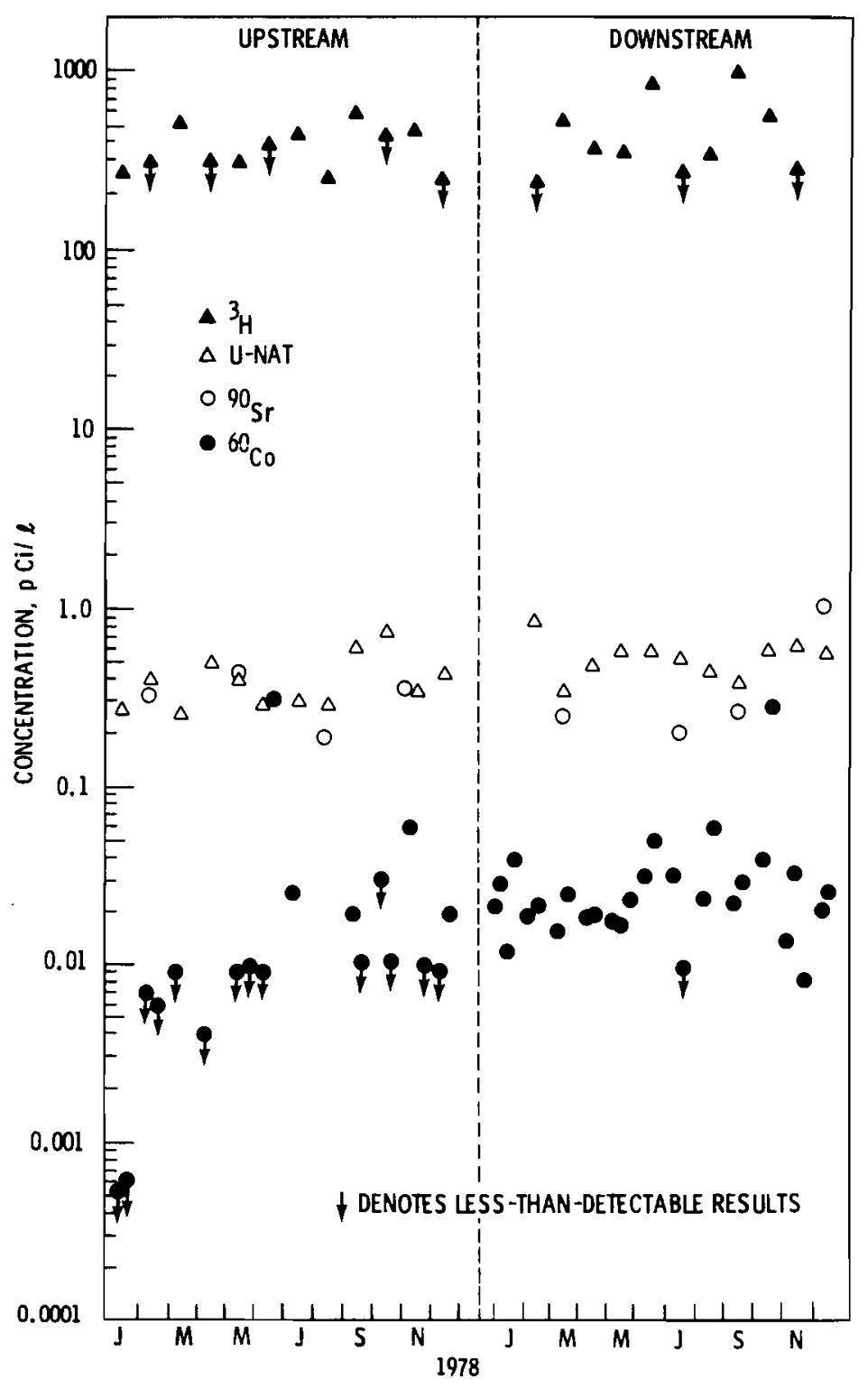

FIGURE 4. Upstream and Downstream Concentrations of Radionuclides in Columbia River Water

TABLE 5. Radiological Analyses of Richland Drinking Water

\begin{tabular}{|c|c|c|c|c|c|c|}
\hline \multirow[b]{2}{*}{ Radionuclide } & \multirow[b]{2}{*}{$\begin{array}{l}\text { No. of } \\
\text { Samples }\end{array}$} & \multirow[b]{2}{*}{$\begin{array}{c}\text { Detection } \\
\text { Limit } \\
\end{array}$} & \multicolumn{4}{|c|}{ Concentration ( $\mathrm{pC} i / \ell)$} \\
\hline & & & Maximum & Minimum & $\begin{array}{l}\text { Annua } 1 \\
\text { Average (a) }\end{array}$ & $\begin{array}{l}\text { State } \\
\text { Standard }\end{array}$ \\
\hline $\begin{array}{l}\text { Gross Alpha } \\
\text { Gross Beta }\end{array}$ & $\begin{array}{l}51 \\
51\end{array}$ & $\begin{array}{l}0.4 \\
5\end{array}$ & $\begin{array}{l}2.3 \\
7.8\end{array}$ & $\begin{array}{l}\star \\
\star\end{array}$ & $\begin{array}{l}<0.7 \\
<5.2\end{array}$ & $\begin{array}{r}5 \\
50\end{array}$ \\
\hline
\end{tabular}

(a) A less-than-detectable value was calculated for the average, assuming that all less-than-detectable results were equal to the detection limit.

* Less than detectable. 


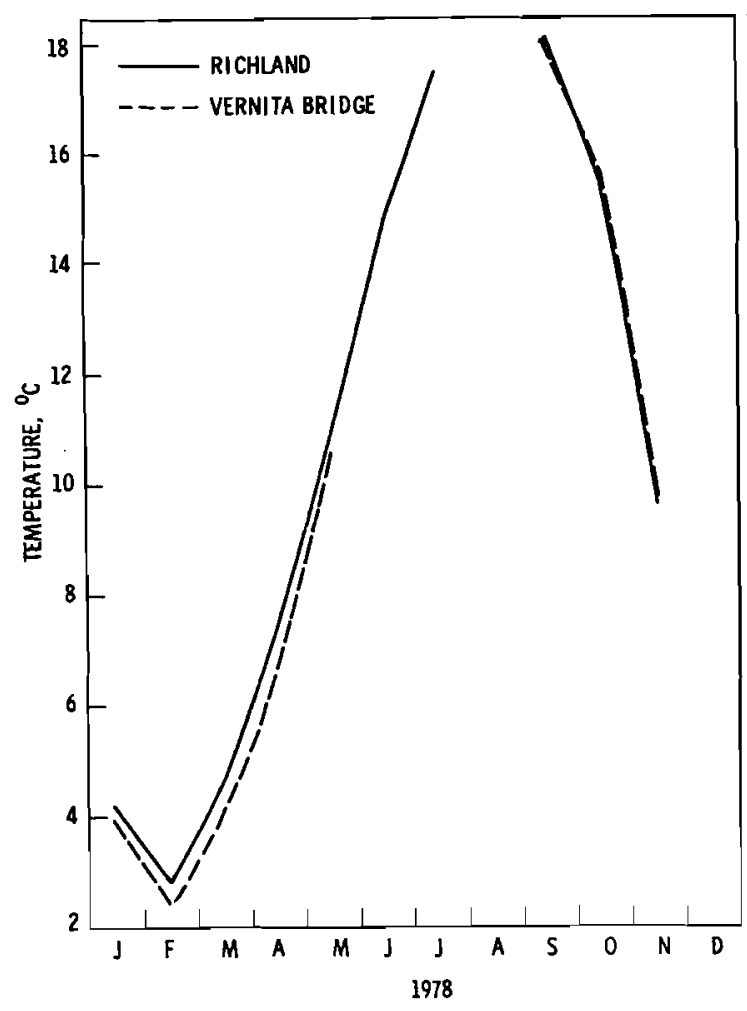

FIGURE 5. Average Monthly Water Temperatures at Richland and Vernita

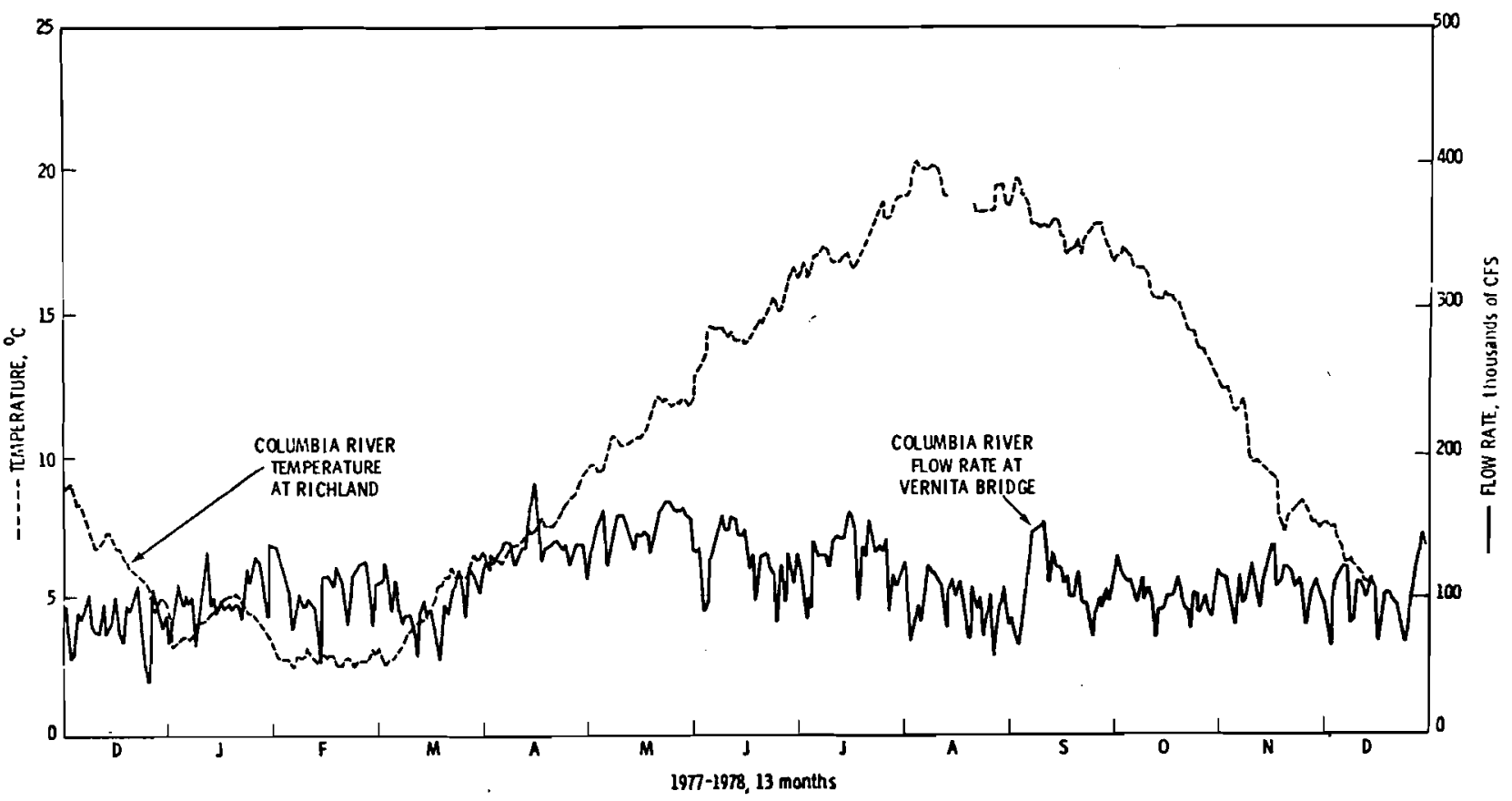

FIGURE 6. Daily Variation in Mean Temperature and Flow Rate 


\section{BIOLOGICAL ANALYSES}

Monthly measurements of total coliforms, fecal coliforms, and biological oxygen demand (BOD) were made on grab samples taken at Vernita Bridge (upstream from Hanford) and at Richland. The data, summarized in Table 6 , indicate an increase in total and fecal coliform concentrations downstream from Hanford. These increases are attributed to drainage from farm activities and to wildlife. The Hanford stretch of the river serves as a refuge for large populations of waterfowl, especially in the autumn.

\section{CHEMICAL ANALYSES}

Grab samples taken at Vernita Bridge and Richland during 1978 were also subjected to chemical analyses. The nitrate concentration, pH, turbidity, and dissolved oxygen content were determined. The results were similar at the two locations and were well within applicable standards adopted by the state of Washington for Class A rivers. (See Appendix A.)

Virtually all of the $\mathrm{pH}$ measurements were well within the 6.5 to 8.5 standard although two downstream measurements showed pHs of 9.2 and 8.6. Upstream pHs were elevated during the same period.
The state of Washington's turbidity standard requires that any increase due to use of the river will be less than or equal to 5 JTU (Jackson Turbidity Units) above the background levels. No differences were observed between Vernita Bridge and Richland, hence the values in Table 6 are assumed to represent normal background turbidity in the river.

The average values for dissolved oxygen in the river at both Vernita Bridge and Richland are well above the standard's minimum of $8 \mathrm{mg} / \mathrm{l}$.

\section{WASTEWATER DISCHARGES TO THE COLUMBIA RIVER}

Wastewater is discharged at nine points along the Hanford reach of the Columbia River. These discharges consist of backwash water from water intake screens, cooling water, water storage tank overflow, and fish hatchery wastewater. Effluents from each of these outfalls are routinely monitored as required by the National Pollutant Discharge Elimination System (NPDES) permit. Among the effluent characteristics monitored are total flow, suspended solids, settleable solids, temperature, oils and grease, free available chlorine, and $\mathrm{pH}$, depending on the nature of the effluent. During 1978, effluents were within the discharge limitations provided in the NPDES permit, with a few isolated exceptions.

TABLE 6. Columbia River Chemical and Biological Analyses

\begin{tabular}{|c|c|c|c|c|c|c|c|c|c|c|}
\hline \multirow[b]{2}{*}{ Analysis } & \multirow[b]{2}{*}{ Units } & \multirow[b]{2}{*}{$\begin{array}{c}\text { State } \\
\text { Standard } \\
\end{array}$} & \multirow[b]{2}{*}{$\begin{array}{r}\text { No. of } \\
\text { Samples } \\
\end{array}$} & \multicolumn{3}{|c|}{ Vernita } & \multirow[b]{2}{*}{$\begin{array}{r}\text { No. of } \\
\text { Samples } \\
\end{array}$} & \multicolumn{3}{|c|}{ Richland (a) } \\
\hline & & & & Maximum & Minimum & $\begin{array}{c}\text { Annual (b) } \\
\text { Average }\end{array}$ & & Maximum & Minimum & $\begin{array}{l}\text { Annual (b) } \\
\text { Average (b) }\end{array}$ \\
\hline $\mathrm{NO}_{3}^{-}$ & $\mathrm{ppm}$ & 45 & 51 & 0.82 & $<0.10$ & $<0.29$ & 51 & 1.4 & $<0.10$ & $<0.33$ \\
\hline $\mathrm{pH}$ & & 6.5 to 8.5 & 47 & 8.5 & 7.1 & & 46 & 9.2 & 7.2 & \\
\hline Turbidity & $\mathrm{JTU}^{(\mathrm{c})}$ & $5+$ Bkgd & 45 & 2.7 & 0.70 & $1.7 \pm 0.9$ & 44 & 2.7 & 0.72 & $1.7 \pm 0.8$ \\
\hline Dissolved $\mathrm{O}_{2}$ & $\mathrm{mg} / \mathrm{l}$ & 8 & 39 & 15.2 & 9.1 & $12 \pm 3$ & 40 & 15.6 & 8.1 & $12 \pm 4$ \\
\hline Total Coliforms & No. $/ 100 \mathrm{ml}$ & - & 13 & 920 & 2.0 & $70^{(d)}$ & 13 & 2400 & 8.0 & $130^{(d)}$ \\
\hline Fecal Coliforms & No. $/ 100 \mathrm{ml}$ & 100 & 13 & 5 & $<2.0$ & $2^{(d)}$ & 13 & 14 & $<2.0$ & $7^{(\mathrm{d})}$ \\
\hline$B O D^{(e)}$ & $\mathrm{mg} / \mathrm{l}$ & - & 13 & 6.9 & 0.50 & $2.0 \pm 3.4$ & 13 & 3.7 & 0.50 & $1.6 \pm 1.7$ \\
\hline
\end{tabular}

(a) $\mathrm{pH}$, turbidity and dissolved $\mathrm{O}_{2}$ samples were obtained from 300 Area sanitary water pumping dock.

(b) Average \pm two standard deviations is shown if all analyses were positive. Otherwise, a less-than-detectable value was calculated from all results, assuming that all less-than-detectable results were equal to the detection limit for the analysis.

(c) Jackson Turbidity Units.

(d) Annual median.

(e) Biological Oxygen Demand. 
Foodstuffs, including milk, beef, chicken, eggs, fruit, and leafy vegetables, were collected from local farms and commercial outlets for analysis of gammaemitting radionuclides and ${ }^{90} \mathrm{Sr}$. Since the Riverview farming area is irrigated with Columbia River water that has passed the Hanford Site, samples of foodstuffs were obtained from this area. The 1978 measurements indicated no observable impact from current or past Hanford operations. Elevated levels of ${ }^{131}$ I were observed in local milk samples following an atmospheric nuclear detonation on March 15, 1978, by the People's Republic of China. The maximum dose to the infant thyroid was calculated to be less than 1 mrem.

\section{$\underline{\text { MILK }}$}

Milk was sampled every 2 weeks at five farms near the Hanford Site, along with a composite sample collected from four other farms across the Columbia River from Hanford. Monthly samples were also obtained from two commercial suppliers. Farm locations are shown in Figure 7 . Each milk sample was analyzed by gamma spectrometry for gammaemitting radionuclides and by specific analysis for $131_{\mathrm{I}}$. Analyses for $90 \mathrm{Sr}$ were made on a quarterly basis.

Analytical results obtained from samples collected during 1978 are summarized in Table 7. Potassium-40, a naturally-occurring radionuclide, was most abundant in the milk samples. Strontium-89 and strontium-90 were found in many milk samples at levels attributed to worldwjde fallout. The maximum concentrations of $13 I_{I}$ in $\mathrm{mi} i \mathrm{k}$ were observed following the March 15 Chinese atmospheric nuc lear detonation.

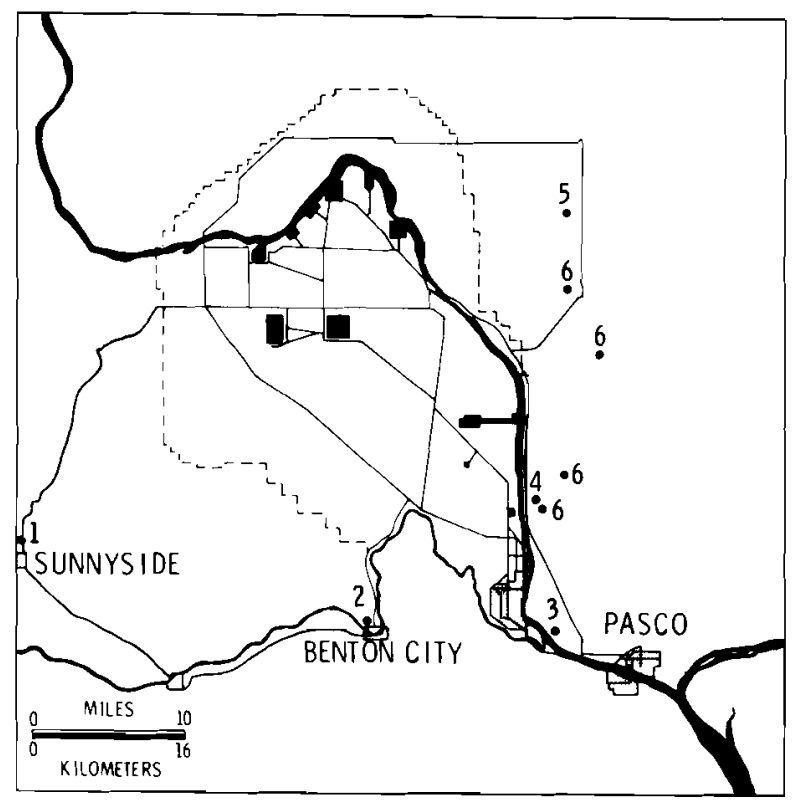

FIGURE 7. Milk Sampling Locations

TABLE 7. Radionuclides in Milk

\begin{tabular}{|c|c|c|}
\hline $\begin{array}{l}\text { Concentration Guid } \\
\text { Location }\end{array}$ & $\begin{array}{l}\text { (a) } \\
\text { Map } \\
\text { Location } \\
\end{array}$ & $\begin{array}{l}\text { No. of } \\
\text { Samples }(b)\end{array}$ \\
\hline Riverview & 3 & 26 \\
\hline Wahluke & 5 & 25 \\
\hline Sagemoor Vicinity & 4 & 26 \\
\hline Benton City & 2 & 26 \\
\hline Sunnyside & 1 & 26 \\
\hline Composite & 6 & 26 \\
\hline Commercial $\|^{(d)}$ & & 13 \\
\hline Cormercial $* 2^{(d)}$ & & 13 \\
\hline
\end{tabular}

\begin{tabular}{|c|c|c|c|c|c|c|c|c|}
\hline & & & \multicolumn{6}{|c|}{ Concentrations $\left(10^{-9} \mu \mathrm{Ci} / \mathrm{ml}\right)$} \\
\hline \multicolumn{3}{|c|}{${ }^{40} \mathrm{~K}$} & \multicolumn{3}{|c|}{${ }^{89} \mathrm{Sr}$} & \multicolumn{3}{|c|}{${ }^{90} \mathrm{Sr}$} \\
\hline & 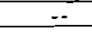 & & & 2000 & & & 200 & \\
\hline Maximum & Minimum & Average $^{(c)}$ & Maximum & Minimum & Average ${ }^{(c)}$ & Maximum & Minimum & Average ${ }^{(c)}$ \\
\hline 1300 & 710 & $960=210$ & 1.1 & * & $<1.0$ & 2.9 & 1.6 & 2.3 \\
\hline 1100 & 780 & $950=200$ & & & & 1.9 & * & $<1.2$ \\
\hline 1400 & 800 & $1100 \pm 270$ & 1.6 & * & $<1.1$ & 2.5 & * & $<1.0$ \\
\hline 1100 & 780 & $890 \pm 400$ & & & & 3.4 & 1.1 & 1.8 \\
\hline 1100 & 730 & $940 \div 170$ & 1.2 & * & $<1.0$ & 1.9 & $\star$ & $<0.9$ \\
\hline 1200 & 800 & $980 \simeq 190$ & & & & 1.3 & * & $<0.9$ \\
\hline 1100 & 850 & $990 \div 160$ & 1.1 & * & $<1.0$ & 3.8 & 1.4 & 2.7 \\
\hline 1100 & 740 & $940 \pm 170$ & & & & 3.4 & 1.4 & 2.2 \\
\hline
\end{tabular}

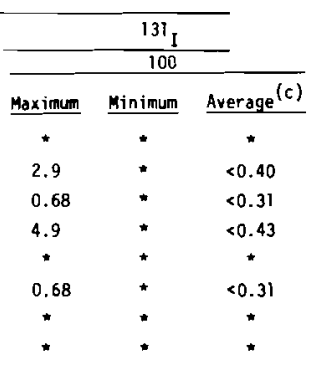

(a) Strontium-90, strontium-89, and iodine-131 concentration quides in milk are established by the Federal Radiation Council. Potassium-40 is a

(b) Total number of samples collected. All samples were analyzed for ${ }^{131} 1$, with a lesser number analyzed for gamm-emitting radionuclides, ${ }^{89} \mathrm{Sr}$, and.

c) Average \pm two standard deviation is shown if all analyses were positive. 0therwise, a less-than-detectable value was calculated from all the (d) Commercial sources obtain milk from two different watersheds: Commercial $\#$, west of the Cascades mountain range; Commercial 2 , east of the
Cascades.

* Less than detectable. Approximate detection limits were: ${ }^{40} \mathrm{~K}, 700 \times 10^{-9} \mu \mathrm{Ci} / \mathrm{ml} ;{ }^{89} \mathrm{Sr}, 1.0 \times 10^{-9} \mu \mathrm{Ci} / \mathrm{ml} ;{ }^{90} \mathrm{Sr}, 0.7 \times 10^{-9}{ }_{\mu C \mathrm{C} / \mathrm{ml}}$; 
The ${ }^{131}$ I concentrations observed in milk during March and April at a milk sampling 10cation in the vicinity of the Hanford Site are shown in Figure $8 .(\mathrm{a})$ An assessment was made of the maximum thyroid dose that would be received by an infant who consumed 1 liter per day of milk containing the average $131_{\text {I concentrations shown in }}$ Figure 8. The total potential dose calculated using the techniques of the Environmental Protection Agency $(9)$ is 0.6 mrem.

Samples of cows' milk and forage were collected from local dairies from April through September, 1978, and analyzed for the ir 129 I content. One dairy also provided samples of goats' milk. Preliminary analysis of the data indicates that none of the samples contained unusually high levels of 129 . The levels found appear to represent 129 I in worldwide fallout. Concentrations in milk ranged from $6 \times 10^{-5}$ to $3 \times 10^{-3}$ $\mathrm{pCi} / \mathrm{l}$ with a median value of $8 \times 10^{-4} \mathrm{pCi} / \mathrm{l}$. Concentrations in forage samples ranged from $4 \times 10^{-6}$ to $4 \times 10^{-5} \mathrm{pCj} / \mathrm{g}$ (dry wt) with a median value of $2 \times 10^{-5} \mathrm{pCi} / \mathrm{g}$ (dry wt). The average 129 I content of goats' milk samples was slightly higher than that of cows' milk samples. These data represent baseline information and will be compared to future data from samples collected when FFTF and other new nuclear facilities at Hanford are operational.

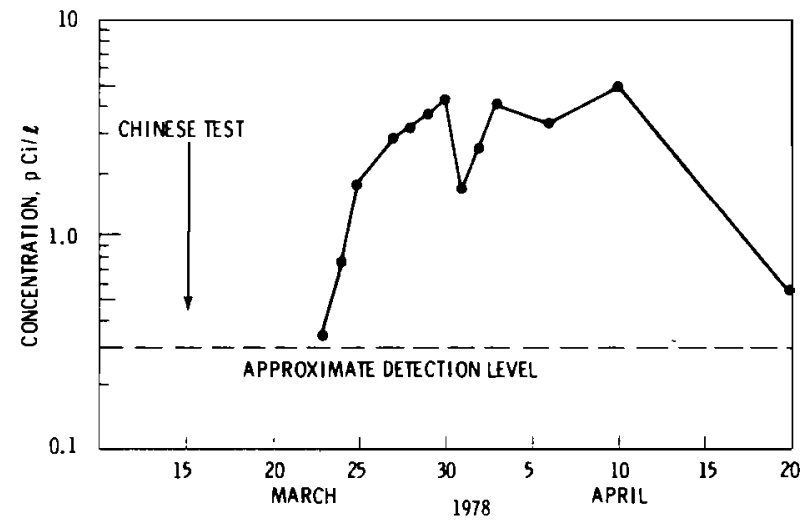

FIGURE 8. Iodine-131 Concentrations in Milk Following March Chinese Test

\section{BEEF, CHICKEN, AND EGGS}

Samples of beef, chicken, and eggs were collected from the Riverview area and from a commercial source for analys is by gamma spectrometry and specific analys is for $90 \mathrm{Sr}$. The results of these analyses are shown in

Table 8.

Naturally-occurring $40 \mathrm{~K}$ was essentially the only radionuclide detected in the samples analyzed. Strontium-90 and $137 \mathrm{Cs}$ from worldwide fallout were detected in one sample of beef at concentrations only slightly above the actual detection limit. Concentrations of all other artificially-produced radionuclides were below the detection limits. These results indicate that any cumulative impact from past Hanford releases on the radionuclide content of these foodstuffs is nil.

\section{FRUIT AND LEAFY VEGETABLES}

Samples of fruit and leafy vegetables (spinach, leaf lettuce, turnip greens, and mustard greens) were obtained during the growing season from a number of farms near to and distant from the Hanford Site. The sample locations at Riverview, Ringold, and in the Sagemoor vicinity are all near the site perimeter. The balance of the sample locations are at distances of 8 to $75 \mathrm{kilo-}$ meters ( 5 to 47 miles) from the nearest site boundary.

All samples were analyzed by gamma spectrometry for gamma-emitting radionuclides. Radiochemical techniques were used for the $90 \mathrm{Sr}$ analyses. Only the edible portions of the fruit and vegetables were analyzed. Results for 1978 are summarized in Table 9 .

of the artificially-produced radionuclides, on ly $90 \mathrm{Sr}$ was detected in some samples at concentrations near the detection limit. Comparison of distant samples with perimeter samples shows that there is no significant difference and that Hanford operations had no detectable impact on radionuclide concentrations in fruit and leafy vegetables.

(a) $1 \mathrm{pCi} / 2=10^{-9} \mu \mathrm{Ci} / \mathrm{ml}$. 
TABLE 8. Radionuclides in Meat, Chicken, and Eggs Concentration $\left(10^{-6} \mu \mathrm{Ci} / \mathrm{g}\right.$, Wet Weight)

\begin{tabular}{|c|c|c|c|c|c|c|c|c|c|c|}
\hline \multirow[b]{2}{*}{ Location } & \multirow[b]{2}{*}{$\begin{array}{r}\text { No. of } \\
\text { Samples }\end{array}$} & \multicolumn{3}{|c|}{$40_{K}$} & \multicolumn{3}{|c|}{${ }^{90} \mathrm{Sr}$} & \multicolumn{3}{|c|}{${ }^{137} \mathrm{Cs}$} \\
\hline & & Maximum & Minimum & Average $^{(a)}$ & Maximum & Minimum & Average $^{(a)}$ & Maximum & Minimum & Average \\
\hline Beef & & & & & & & & & & \\
\hline Commercial & 4 & 2.4 & 1.9 & $2.2 \pm 0.4$ & 0.01 & * & $<0.005$ & 0.05 & $\star$ & $<0.05$ \\
\hline Riverview & 1 & & & 2.3 & & & $\star$ & & & $\star$ \\
\hline Chicken & & & & & & & & & & \\
\hline Commercial & 2 & 1.4 & 1.3 & 1.4 & $\star$ & $\star$ & $\star$ & $\star$ & $\star$ & $\star$ \\
\hline Riveryiew & 4 & 1.8 & 1.1 & $1.5 \pm 0.6$ & * & $\star$ & $\star$ & $\star$ & 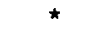 & $\star$ \\
\hline Sagemoor Vicinity & 2 & 2.0 & 1.9 & 2.0 & * & $\star$ & $\star$ & $\star$ & * & $\star$ \\
\hline Sunnyside & 2 & 2.6 & 2.0 & 2.3 & * & $\star$ & $\star$ & $\star$ & $\star$ & $\star$ \\
\hline Eggs & & & & & & & & & & \\
\hline Conmercial & 2 & 0.89 & 0.73 & 0.81 & * & $\star$ & $\star$ & $\star$ & $\star$ & $\star$ \\
\hline Riverview & 13 & 0.96 & * & $<0.81$ & * & $\star$ & $\star(b)$ & $\star$ & * & $\star$ \\
\hline Sagemoor Vicinity & 2 & 0.89 & 0.87 & 0.88 & * & $\star$ & $\star$ & $\star$ & * & $\star$ \\
\hline Sunnyside & 2 & 0.94 & 0.87 & 0.91 & * & $\star$ & $\star$ & $\star$ & * & $\star$ \\
\hline
\end{tabular}

(a) Average \pm two standard deviations is shown if all analyses were positive. Otherwise, a less-than-detectable value was calculated from all results, assuming that all less-than-detectable results were equal to the detection limit for the analysis.

(b) Strontium-90 analysis was done on only four samples. * Less than detectable. Approximate detection limits were: $40 \mathrm{~K}, 0.6 \times 10^{-6} \mu \mathrm{Ci} / \mathrm{g} ;{ }^{90} \mathrm{Sr}, 0.001 \times 10^{-6} \mu \mathrm{Ci} / \mathrm{g}$;
$137 \mathrm{Cs}, 0.04 \times 10^{-6} \mu \mathrm{Ci} / \mathrm{g}$.

\section{TABLE 9. Radionuclides in Fruit and Leafy Vegetables}

\begin{tabular}{|c|c|c|c|c|c|c|c|c|c|c|c|}
\hline \multirow[b]{3}{*}{ Location } & \multirow[b]{3}{*}{ Type } & \multirow{3}{*}{$\begin{array}{r}\text { No. of } \\
\text { Samples }\end{array}$} & \multicolumn{6}{|c|}{ Concentration $\left(10^{-6} \mu \mathrm{Ci} / \mathrm{g}\right.$, wet Weight $)$} & \multirow{2}{*}{\multicolumn{3}{|c|}{${ }^{137} \mathrm{Cs}$}} \\
\hline & & & \multicolumn{3}{|c|}{${ }^{40} 0_{K}$} & \multicolumn{3}{|c|}{${ }^{90} \mathrm{Sr}$} & & & \\
\hline & & & Maximum & Minimum & Average $^{(a)}$ & Maximum & Minimum & Average $^{(a)}$ & \multirow[t]{2}{*}{ Maximum } & \multirow[t]{2}{*}{ Minimum } & \multirow[t]{2}{*}{ Average $^{(a)}$} \\
\hline \multicolumn{9}{|l|}{ Fruit } & & & \\
\hline Sagemoor Vicinity & Pears & 1 & & & * & & & & & & $\star$ \\
\hline Sagemoor Vicinity & Peaches & 1 & & & 1.0 & & & & & & $\star$ \\
\hline Sagemoor Vicinity & Grapes & 1 & & & 1.8 & & & & & & $\star$ \\
\hline Sagemoor Vicinity & Apples & 1 & & & $\star$ & & & & & & $\star$ \\
\hline \multicolumn{12}{|l|}{ Leafy Vegetables } \\
\hline Riverview & & 5 & 4.0 & $\star$ & $<2.5$ & 0.06 & 0.01 & $0.03 \pm 0.04$ & $\star$ & $\star$ & $\star$ \\
\hline Ringold & & 1 & & & 2.1 & & & $\star$ & & & $\star$ \\
\hline Sagemoor Vicinity & & 1 & & & 3.8 & & & & & & $\star$ \\
\hline Benton City & & 1 & & & 2.7 & & & $\star$ & & & $\star$ \\
\hline Sunnyside & & 1 & & & 3.6 & & & 0.02 & & & $\star$ \\
\hline Othelio & & 1 & & & 1.9 & & & $\star$ & & & $\star$ \\
\hline Walla Walla & & 2 & 7.5 & $\star$ & $<4.8$ & 0.01 & 0.007 & 0.009 & $\star$ & $\star$ & $\star$ \\
\hline Commercial & & 1 & & & * & & & 0.005 & & & $\star$ \\
\hline
\end{tabular}

(a) Average \pm two standard deviations is shown if all analyses were positive. 0therwise, a less-than-detectable value was calculated from all the results. assumina that all less-than-detectable results were equal to the detection limit for the analysis.

* Less than detectable. Approximate detection 1 imits were: ${ }^{40} \mathrm{~K}, 1.0 \times 10^{-6} \mu \mathrm{Ci} / \mathrm{g} ;{ }^{90} \mathrm{Sr}, 0.002 \times 10^{-6} \mu \mathrm{Ci} / 9:{ }^{137} \mathrm{Cs}, 0.05 \times 10^{-6} \mu \mathrm{Ci} / \mathrm{g}$. 


\section{WILDLIFE}

Wildlife--deer, game birds, and fish--were collected and analyzed for gammaemitting radionuclides and in some cases ${ }^{90} \mathrm{Sr}$. The wildlife are a potential pathway for the exposure of small groups of people who hunt or fish near the Hanford Site. Measurements during 1978 did not show any distinguishable impact from Hanford operations.

$\underline{D E E R}$

During 1978 all deer samples were obtained from "road kills" on the Hanford Site. Samples of muscle tissue were analyzed to determine the concentration of gamma-emitting radionuclides and $90 \mathrm{Sr}$. The resulting data are shown in Table 10.

Naturally-occurring $40 \mathrm{~K}$ and the fission products $90 \mathrm{Sr}$ and $137 \mathrm{Cs}$ were the only radionuclides detected in the deer muscle samples. Only one of the deer samples exceeded the $90 \mathrm{Sr}$ detection limit. Concentrations of ${ }^{137} \mathrm{Cs}$ in the deer samples were all near or below the detection limit. In general, radionuclide concentrations in deer samples collected during 1978 were lower than those observed in the past.

\section{GAME BIRDS}

Game bird samples collected and analyzed included pheasant, quail, ducks, and geese. The results of these analyses are shown in Table 10. Naturally-occurring $40_{K}$ was the on ly garma-emitting radionuclide detected in the game birds. The low concentrations of $137 \mathrm{Cs}$ observed in the past were below the detection limit in 1978 .

All game bird samples except the geese were analyzed for $90 \mathrm{Sr}$. Quail and pheasant from widely scattered locations contained low concentrations of $90 \mathrm{Sr}$ in their muscle tissue. Consumption, by an adult, of all of the muscle tissue $(100 \mathrm{~g})$ from the quail with the maximum $90 \mathrm{Sr}$ concentration $(0.84 \times$ $10^{-6} \mu \mathrm{Ci} / \mathrm{g}$ ) would produce a 50 -yr bone dose commitment of about 1 mrem. This is much less than the radiation dose received from natural sources in the vicinity of Hanford.

FISH

Several varieties of fish (suckers, whitefish, sturgeon, bass, squawfish, stee ihead, and carp) were collected and analyzed during 1978. Only naturally-occurring $40 \mathrm{~K}$ was detected in the fish samples. All other gammaemitting radionuclides were below detectable concentrations.

TABLE 10. Radionuclides in Muscle Tissue of Wildlife

\begin{tabular}{|c|c|c|c|c|c|c|c|c|c|c|}
\hline \multirow[b]{3}{*}{ Wildlife } & \multirow{3}{*}{$\begin{array}{r}\text { No. of } \\
\text { Samples } \\
\end{array}$} & \multicolumn{6}{|c|}{ Concentration $\left(10^{-6} \mu \mathrm{Ci} / \mathrm{g}\right.$, Wet weight) } & \multirow{2}{*}{\multicolumn{3}{|c|}{${ }^{137} \mathrm{Cs}_{\mathrm{s}}$}} \\
\hline & & \multicolumn{3}{|c|}{$40_{K}$} & \multicolumn{3}{|c|}{${ }^{90} \mathrm{Sr}$} & & & \\
\hline & & Maximum & Minimum & Average $^{(\mathrm{a})}$ & Maximum & Minimum & Average (a) $^{(a)}$ & Maximum & Minimum & Average $^{(a)}$ \\
\hline Deer & 5 & 2.2 & 1.8 & $2.0 \pm 0.36$ & 0.24 & * & $<0.19$ & 0.13 & * & $<0.06$ \\
\hline Pheasant & 6 & 2.7 & 3.8 & $2.4 \pm 0.70$ & 0.58 & * & $<0.12$ & * & * & $\star$ \\
\hline Quai? & 4 & $\star$ & * & * & 0.84 & * & $<0.25$ & * & * & $\star$ \\
\hline Ducks & 10 & 3.7 & * & $<2.7$ & 0.13 & * & $<0.03$ & * & $\star$ & * \\
\hline Geese & 2 & 3.0 & 2.2 & 2.6 & & & & * & * & $\star$ \\
\hline Fish & 12 & 2.7 & $\star$ & $<2.7$ & & & & $\star$ & $\star$ & * \\
\hline
\end{tabular}

(a) Average \pm two standard deviations is shown if all analyses were positive. Otherwise, a less-than-detectable value was calculated from all results, assuming that all less-than detectable results were equal to the detection limit for the analysis.

* Less than detectable. Approximate detection limits were: ${ }^{40} \mathrm{~K}, 2.0 \times 10^{-6} \mu \mathrm{Ci} / \mathrm{g} ;{ }^{90} \mathrm{Sr}, 0.05 \times 10^{-6} \mu \mathrm{Ci} / \mathrm{g}$; $137 \mathrm{Cs}, 0.13 \times 10^{-6} \mu \mathrm{Ci} / \mathrm{g}$. 
Surface soil and vegetation samples are collected annually from a number of locations for the purpose of measuring the radionuclide concentrations from worldwide fallout, natural causes, and any cumulative buildup of radionuclides from Hanford operations. The data collected during 1978 indicate that any Hanford contribution to the radionuclide concentrations was indistinguishable from the variability observed in levels of worldwide fallout.

\section{COLLECTION AND ANALYSIS}

Each soil sample analyzed was a composite of five "plugs" of soil collected annually from an area approximately $100 \mathrm{~m}^{2}$. The plugs were approximately $2.5 \mathrm{~cm}$ (1 in.) in depth and $10 \mathrm{~cm}$ ( 4 in.) in diameter. Samples of perennial vegetation, rabbitbrush, sagebrush, and bitterbrush were collected in the immediate vicinity of each soil sampling location. Both sets of samples were analyzed for gamma-emitting radionuclides using a lithium-drifted germanium detector; for plutonium isotopes using alpha spectroscopy; and for $90 \mathrm{Sr}$ and uranium by spec if ic analysis.
The locations of the sample plots are shown in Figure 9. Hanford operations would be expected to contribute much more to the radionuclide concentrations at predominantly downwind locations (Riverview, Byers Landing, Sagemoor, Pettett, Baxter Substation, West End Fir Road, Ringold--locations 1 to 7 ) than to sampling locations lying in other directions (Yakima Barricade, Wahluke \#2, etc.).

\section{SOIL}

Data from soil analyses for 1978 are summarized in Table 11 . The naturally-occurring radionuclides $40 \mathrm{~K}, 224 \mathrm{Ra},{ }^{226} \mathrm{Ra}$, and uranium

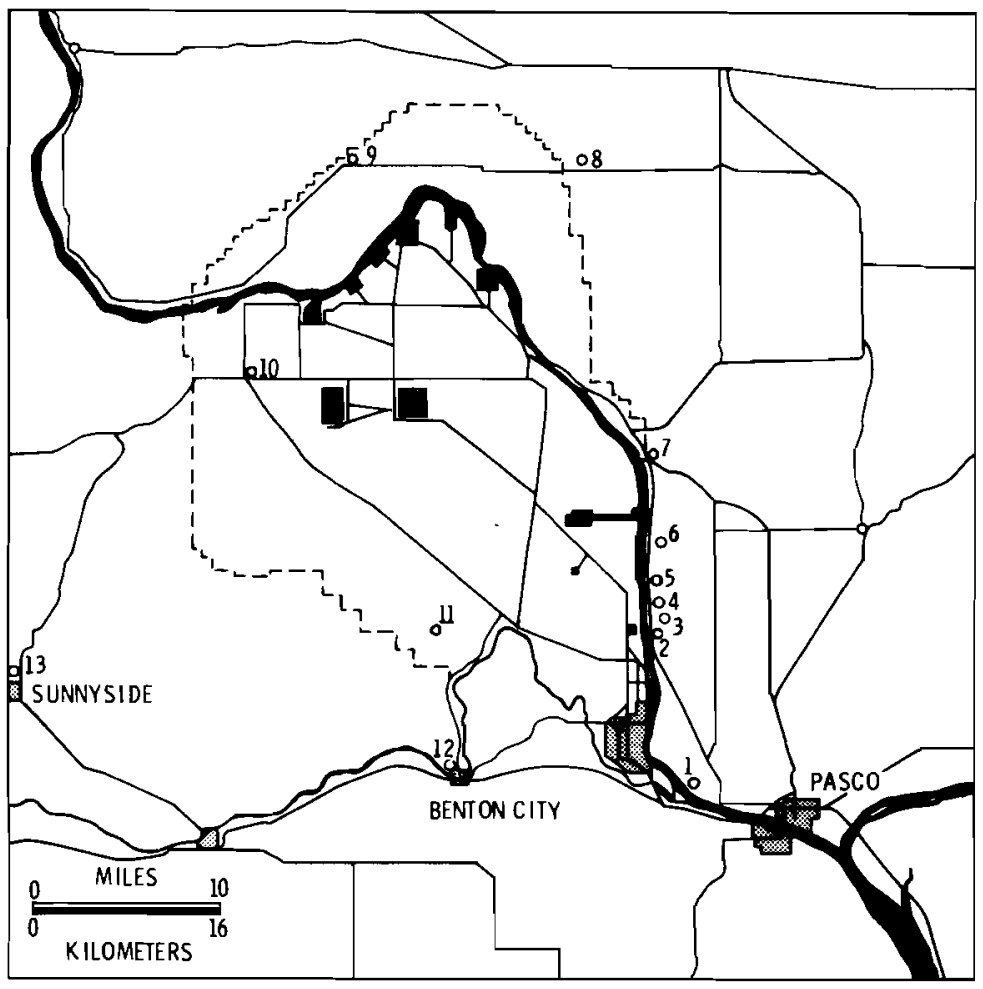

FIGURE 9. Soil and Vegetation Sampling Locations 
TABLE 11. Radionuclides in Soil

Part A: Naturally Occurring

\begin{tabular}{|c|c|c|c|c|c|}
\hline \multirow{2}{*}{ Location } & \multirow[b]{2}{*}{$\begin{array}{l}\text { Map } \\
\text { Location }\end{array}$} & \multicolumn{4}{|c|}{ Concentration $\left(10^{-6} \mu \mathrm{Ci} / \mathrm{g}\right.$, Dry Weight $)$} \\
\hline & & ${ }^{40} \mathrm{~K}$ & ${ }^{224} \mathrm{Ra}$ & ${ }^{226} \mathrm{Ra}$ & Total U \\
\hline Average Detection Limit & & 1.5 & 0.1 & 0.1 & 0.15 \\
\hline Riverview & 1 & 17 & 0.8 & 0.6 & 0.3 \\
\hline Byers Landing & 2 & 17 & 1.3 & 0.9 & 0.4 \\
\hline Sagemoor & 3 & 16 & 1.1 & 0.6 & 0.3 \\
\hline Taylor Flats & 4 & 19 & 1.2 & 0.8 & 1.2 \\
\hline Taylor Flats \#2 & 5 & 18 & 1.1 & 0.7 & 0.6 \\
\hline W. End Fir Road & 6 & 19 & 1.2 & 0.8 & 0.4 \\
\hline Ringold & 7 & 17 & 1.1 & 0.5 & 0.7 \\
\hline Berg Ranch & 8 & 14 & 1.3 & 0.8 & 0.4 \\
\hline Wahluke "2 & 9 & 12 & 1.1 & 0.8 & 0.5 \\
\hline Yakima Barricade & 10 & 16 & 1.3 & 0.8 & 0.2 \\
\hline ALE & 11 & 14 & 1.2 & 0.7 & 0.4 \\
\hline Benton City & 12 & 13 & 1.0 & 0.8 & 0.5 \\
\hline Sunnyside & 13 & 13 & 0.9 & 0.7 & 0.4 \\
\hline Average & & 16 & 1.1 & 0.7 & 0.5 \\
\hline
\end{tabular}

Part B: Artificially Produced

\begin{tabular}{|c|c|c|c|c|c|c|c|c|}
\hline \multirow[b]{2}{*}{ Location } & \multirow[b]{2}{*}{$\begin{array}{c}\text { Map } \\
\text { Location }\end{array}$} & \multicolumn{7}{|c|}{ Diy we } \\
\hline & & ${ }^{90} \mathrm{Sr}$ & ${ }^{95} \mathrm{ZrNb}$ & ${ }^{134} \mathrm{Cs}$ & ${ }^{137} \mathrm{Cs}$ & ${ }^{144} \mathrm{Ce}$ & ${ }^{238} \mathrm{Pu}$ & $239-240 \mathrm{Pu}$ \\
\hline Average Detection Limit & & 0.003 & 0.04 & 0.03 & 0.07 & 0.13 & 0.002 & 0.003 \\
\hline Riverview & 1 & 0.04 & $\star$ & $\star$ & 0.5 & $\star$ & $\star$ & 0.02 \\
\hline Byers Landing & 2 & 0.05 & 0.1 & $\star$ & 1.1 & $\star$ & * & * \\
\hline Sagemoor & 3 & 0.008 & $\star$ & * & 0.1 & 0.3 & * & 0.003 \\
\hline Taylor Flats \#1 & 4 & 0.008 & 0.04 & 0.04 & 0.2 & 0.2 & 0.003 & 0.004 \\
\hline Taylor Flats $\# 2$ & 5 & 0.007 & $\star$ & * & 0.09 & 0.4 & $\star$ & $\star$ \\
\hline W. End Fir Road & 6 & 0.01 & 0.04 & 0.05 & 0.4 & 0.4 & $\star$ & 0.004 \\
\hline Ringold & 7 & 0.03 & $\star$ & * & 1.0 & 0.4 & * & 0.02 \\
\hline Berg Ranch & 8 & 0.01 & 0.9 & 0.06 & 0.6 & 0.4 & * & 0.004 \\
\hline Wahluke \#2 & 9 & 0.01 & 0.04 & 0.06 & 0.3 & 0.4 & * & 0.005 \\
\hline Yakima Barricade & 10 & 0.009 & $\star$ & * & 0.3 & 0.1 & $\star$ & 0.02 \\
\hline ALE & 11 & 0.006 & 0.05 & 0.04 & 0.6 & 0.2 & * & 0.006 \\
\hline Benton City & 12 & 0.03 & 0.04 & 0.04 & 0.5 & 0.2 & $\star$ & 0.01 \\
\hline Sunnyside & 13 & 0.01 & 0.04 & $\star$ & 0.6 & 0.3 & * & 0.008 \\
\hline Average $^{(a)}$ & & 0.02 & $<0.11$ & $<0.03$ & 0.5 & $<0.3$ & $<0.002$ & $<0.009$ \\
\hline
\end{tabular}

(a) Average is shown if radionuclide was detected at all locations. 0therwise, a less-than-detectable value was calculated from all results, assuming that all less-than-detectable results were equal to the detection limit for the analysis.

* Less than detectable. 
were observed at higher concentrations in the soil than any of the artificiallyproduced radionuclides. While there were considerable differences in radionuclide concentration between sample sites, no geographical pattern was detected. This indicates that any Hanford contribution was indistinguishable from the variability observed in radionuclide concentrations from wor ldwide fallout. The maximum $90 \mathrm{Sr}$ concentration, $0.05 \times 10^{-6} \mu \mathrm{Ci} / \mathrm{g}$, was observed at Byers Landing, a predominantly downwind direction. Peak 239Pu concentrations of $0.02 \times$ $10^{-6} \mu \mathrm{Ci} / \mathrm{g}$ were observed at Riverview, Ringold, and the Yakima Barricade. All of these results, while much higher than those from other locations, are similar to maximum values measured in past years and indicate the variability of soil concentrations attributed to worldwide fallout.

\section{VEGETATION}

Shown in Table 12 are the data obtained in 1978 from vegetation samples. Naturallyoccurring $40_{\mathrm{K}}$ is the major radionuclide component found in vegetation. Concentrations of short-lived artificially-produced radionuclides attributed to worldwide fallout have declined significantly in recent years. Other radionuclides were present at about the same concentrations as in previous years, again indicating no detectable Hanford contribution.

\section{TABLE 12. Radionuclides in Vegetation}

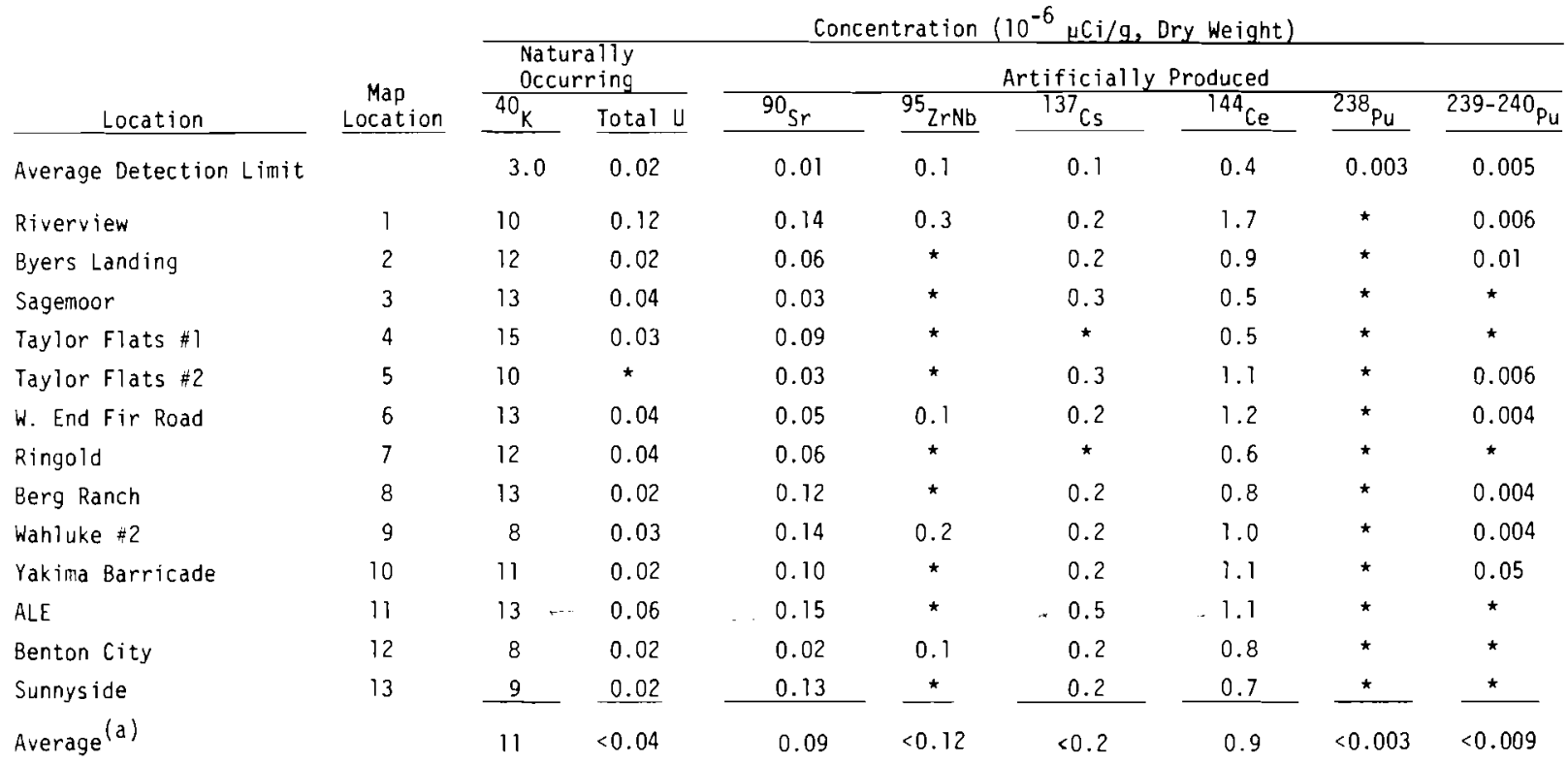

(a) Average is shown if radionuclide was detected at all locations. Otherwise, a less-than-detectable value was calculated from all results, assuming that ail less-than-detectable results were equal to the detection limit for the analysis.

* Less than detectable. 


\section{EXTERNAL RADIATION}

External radiation levels were measured using thermoluminescent dosimeters at a11 air sampling locations in the Hanford environs. The spatial pattern of recorded doses was used to determine any contribution attributable to Hanford operations, since releases from Hanford would contribute primarily to measurements made at downwind locations. Dosimeters were also used to measure the dose received along the Columbia River islands and shoreline near the Hanford Site, and the immersion dose in Columbia River water at two locations. The 1978 measurements at air sampling locations showed no observable impact from Hanford operations. However, several measurements on the Columbia River islands and along the shoreline continued to show slightly elevated dose rates attributed predominantly to residual ${ }^{60}$ Co activity in river sediments. This activity remains from past direct use of river water to cool production reactors. The incremental increase in radiation exposure to recreational users of the river is insignificant.

\section{HANFORD ENVIRONS}

Thermoluminescent dosimeters (TLDs) were located at all of the perimeter and distant air sampling locations shown in Figure 2 (page 6). The dosimeters consisted of $\mathrm{CaF}_{2}$ : Mn chips (Harshaw TLD-400) encased in an opaque plastic capsule lined with $0.025 \mathrm{~cm}$ (0.01 in.) of tantalum and $0.005 \mathrm{~cm}$ (0.002 in.) of lead to flatten the lowenergy response. (10) The dosimeters were mounted $1 \mathrm{~m}$ above ground level and changed every 4 weeks.

The results presented in Table 13 show that the average annual dose is essentially the same for perimeter and distant stations. A log normal probability plot of the individual data points for distant and perimeter locations (Figure 10 ) shows the similarity of the measurements, indicating that Hanford contributions were indistinguishable from the background dose.

From information in Table 13, the external background dose received by the population in the Hanford environs can be est imated. The mean measured dose was about 67 mrem per year (here, 1 mrem equals $1 \mathrm{mrad}$ ). To this dose, 6 mrem per year must be added to account for the fast neutron component of cosmic radiation. (11) Thus the population would receive a dose of about $73 \mathrm{mrem}$ per year from external radiation. To estimate the total background dose (external plus interna 1), the 25 mrem received by the body from naturally-occurring radionuclides, primarily $40 \mathrm{~K}$, must be included. Therefore,
TABLE 13. Environmental Radiation Dose Measurements in the Hanford Vicinity

\begin{tabular}{|c|c|c|c|c|}
\hline \multirow{2}{*}{ Location } & \multirow{2}{*}{$\begin{array}{r}\text { No. of } \\
\text { Samples }\end{array}$} & \multicolumn{3}{|c|}{ Dose $(\operatorname{mrad} / \mathrm{yr})^{(a)}$} \\
\hline & & Maximum & Minimum & Average \\
\hline \multicolumn{5}{|l|}{ Perimeter Stations } \\
\hline $\begin{array}{l}\text { Rattlesnake Springs } \\
\text { ALE } \\
\text { Benton City } \\
\text { Yakima Barricade } \\
\text { Vernita } \\
\text { Wahluke } 2 \\
\text { Othello } \\
\text { Connell } \\
\text { Berg Ranch } \\
\text { Wahluke Watermaster } \\
\text { Cooke Brothers } \\
\text { Richland } \\
\text { Pasco } \\
\text { Byers Landing } \\
\text { Sagemoor } \\
\text { Pettett Farm } \\
\text { Fir Road } \\
\text { RRC CP } 164 \\
\text { RRC CP } 63 \\
1100 \text { Area }\end{array}$ & $\begin{array}{r}13 \\
13 \\
13 \\
13 \\
13 \\
13 \\
11 \\
12 \\
13 \\
13 \\
13 \\
12 \\
13 \\
12 \\
12 \\
11 \\
13 \\
8 \\
4 \\
12\end{array}$ & $\begin{array}{l}77 \\
88 \\
69 \\
84 \\
80 \\
84 \\
66 \\
66 \\
77 \\
69 \\
77 \\
77 \\
77 \\
84 \\
80 \\
69 \\
84 \\
73 \\
62 \\
84\end{array}$ & $\begin{array}{l}66 \\
69 \\
44 \\
73 \\
51 \\
55 \\
51 \\
55 \\
40 \\
44 \\
47 \\
58 \\
62 \\
73 \\
44 \\
29 \\
40 \\
55 \\
55 \\
51\end{array}$ & $\begin{array}{l}69 \pm 7.3 \\
77 \pm 11 \\
57 \pm 13 \\
77 \pm 9 \\
73 \pm 14 \\
73 \pm 14 \\
56 \pm 8.8 \\
62 \pm 9.8 \\
70 \pm 19 \\
65 \pm 14 \\
61 \pm 15 \\
67 \pm 11 \\
67 \pm 11 \\
77 \pm 7.9 \\
68 \pm 18 \\
58 \pm 21 \\
65 \pm 20 \\
66 \pm 14 \\
59 \pm 6.9 \\
64 \pm 21 \\
\end{array}$ \\
\hline \multicolumn{4}{|c|}{ Mean \pm 2 Standard Deviations } & $67 \pm 19$ \\
\hline \multicolumn{5}{|l|}{ Distant Stations } \\
\hline $\begin{array}{l}\text { Walla Walla } \\
\text { McNary } \\
\text { Moses Lake } \\
\text { Washtucna } \\
\text { Sunnyside }\end{array}$ & $\begin{array}{l}12 \\
12 \\
12 \\
12 \\
13\end{array}$ & $\begin{array}{l}88 \\
77 \\
69 \\
69 \\
69\end{array}$ & $\begin{array}{l}44 \\
58 \\
51 \\
55 \\
55\end{array}$ & $\begin{array}{l}64 \pm 21 \\
67 \pm 13 \\
61 \pm 12 \\
62 \pm 9.8 \\
61 \pm 9.1 \\
\end{array}$ \\
\hline \multicolumn{4}{|c|}{ Mean \pm 2 Standard Deviations } & $63 \pm 13$ \\
\hline
\end{tabular}

(a) Total background dose from external irradiation would include an additional dose from the neutron component of cosmic radiation. additional dose from the neutron component of cosmic radiation. of the Hanford region. Monthly measurements were converted to of the Hanford region. Monthly measurements were converted to
equivalent annual dose. Average \pm two standard deviation is shown for each location. 


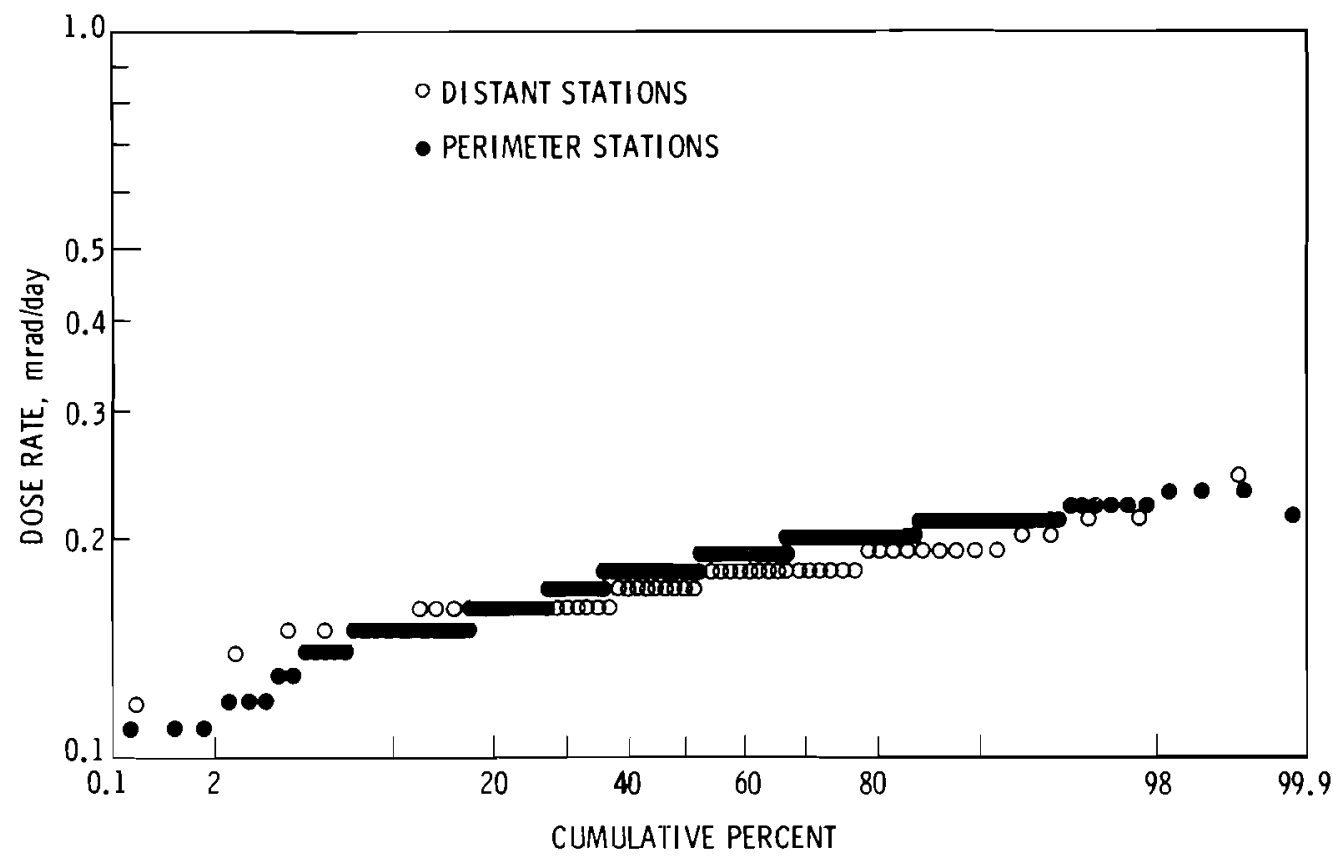

FIGURE 10. Log Normal Probability Plot of Monthly Dose Measurements at Perimeter and Distant Locations

the total background dose received in the Hanford environs during 1978 was approximately 100 mrem per year, as it was during 1977.

\section{COLUMBIA RIVER IMMERSION DOSE}

Environmental dosimeters were submerged in the Columbia River at the two locations labeled in Figure 11: at Coyote Rapids, and at the Richland pumphouse. These dosimeters were collected monthly. The results (shown in Table 14) are similar to those obtained in previous years and show that a swimmer immersed in the Columbia River at Richland would receive a radiation dose rate of approximately $0.004 \mathrm{mrad} / \mathrm{hr}$. By comparison, approximately $0.008 \mathrm{mrad} / \mathrm{hr}$ would be received on 1 and.

\section{COLUMBIA RIVER SHORELINE AND ISLANDS}

Until late 1977, public access to the Hanford reach of the Columbia River between Ringold and Vernita was prohibited. The public now has free access to the river and its islands but is prohibited from landing on the shores of the Hanford reservation. Analyses of sediment samples collected along the Columbia River have shown the presence of a few long-lived radionuclides, primarily ${ }^{60} \mathrm{Co}$, attributable to the past operation of production reactors cooled directly by river water. A 1974 aerial radiation monitoring survey showed low-level deposition of $60 \mathrm{Co}$ over much of the Hanford reach of the river. (12) This activity occurs in sediments along the river's islands, shoreline, and slough areas, gradualiy decreasing downstream from the old production reactor sites, and becoming undetectable below North Richland.

Summarized in Table 15 are data from environmental dosimeters placed at 12 locations along the Columbia River shoreline including three of the larger islands. Placement of the dosimeters is shown by the numbered 10cations in Figure 11 . These sites were selected on the basis of the aerial survey findings; most are located in areas found to have the highest levels of radionuclides in the sediments. These dosimeters provide data on the potential radiation exposure to recreational users of the river.

The maximum external dose rate along the river was measured at the 100-N Trench springs and corresponds to a dose rate of 


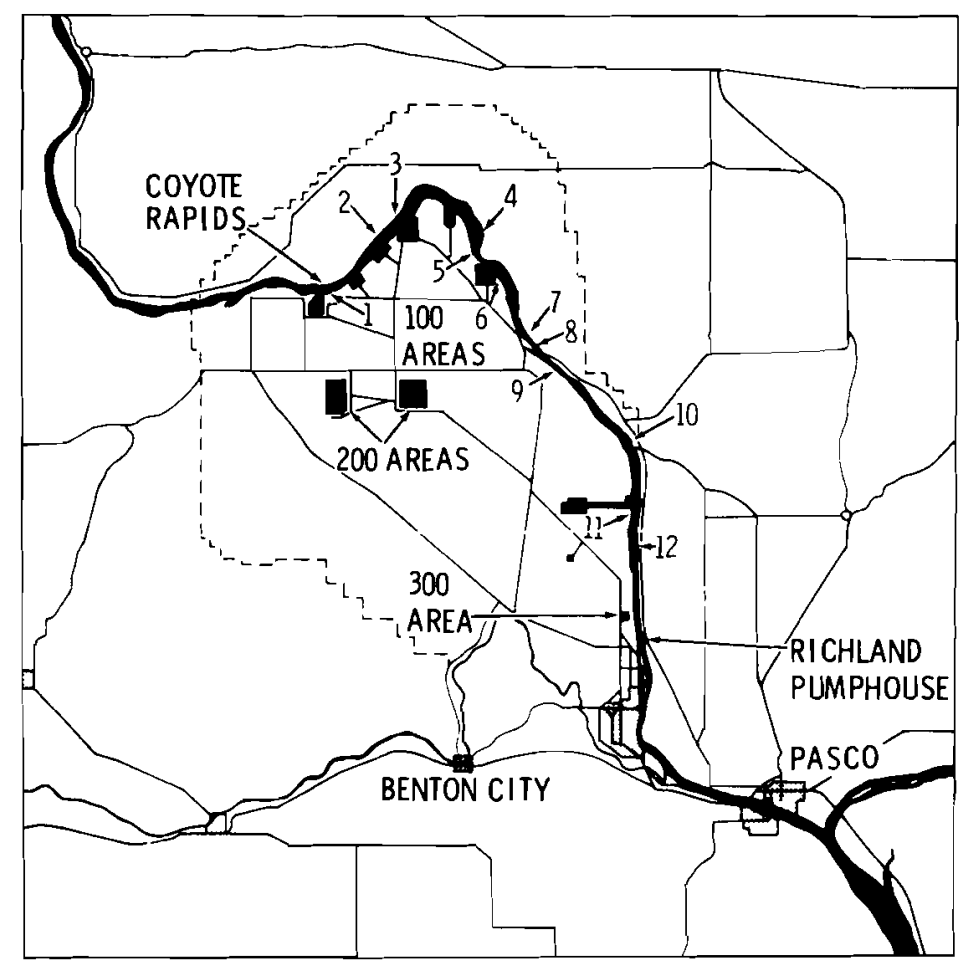

FIGURE 11. Thermoluminescent Dosimeter Locations for Columbia River Immersion and Sediment Measurements

$0.075 \mathrm{mrad} / \mathrm{hr}$ averaged over a 1-month period, or about ten times the general background dose rate at Hanford. Slightly contaminated water seeping from the springs is responsible for the elevated dose rate at this location. Elevated dose rates at the other sites are due primarily to ${ }^{60} \mathrm{Co}_{0}$ in the shoreline sediments. Differences in the ${ }^{60}$ Co concentration from site to site are responsible for the variation in the results. Dose rates along the shorelines get lower each year as the 60 co decays away and is buried by uncontaminated sediments. The average dose rate along the shoreline due to the artificially-produced radionuclides in the sediments decreased about $30 \%$ from 1977 to 1978. Public access to the two highest dose rate areas is prohibited and the average dose rates at the areas to which the public does have free access are just slightly higher than the natural background level (76 mrad/yr versus $67 \mathrm{mrad} / \mathrm{yr}$ ). The incremental increase in radiation exposure to the recreational user of the Hanford reach of the river is insignificant.

TABLE 14. Columbia River Immersion Dose Rate

\begin{tabular}{|c|c|c|c|c|}
\hline \multirow[b]{2}{*}{ Location } & \multirow{2}{*}{$\begin{array}{c}\text { No. of } \\
\text { Measurements }\end{array}$} & \multicolumn{3}{|c|}{ Radiation Dose (mrad/hr)(a) } \\
\hline & & Maximum & Minimum & Average ${ }^{(b)}$ \\
\hline Coyote $\mathrm{F}$ & 8 & 0.005 & 0.004 & $0.004 \pm 0.001$ \\
\hline Richland Pump House & 12 & 0.004 & 0.003 & $0.004 \pm 0.001$ \\
\hline
\end{tabular}

(a) Monthly measurements in mrad were converted to equivalent hourly dose.

(b) Average \pm two standard deviations is shown for each location. 
TABLE 15. Environmental Radiation Dose Measurements Along the Columbia River Shoreline and Islands

\begin{tabular}{|c|c|c|c|c|c|}
\hline \multirow[b]{2}{*}{ Location } & \multirow[b]{2}{*}{$\begin{array}{l}\text { Map } \\
\text { Number } \\
\end{array}$} & \multirow[b]{2}{*}{$\begin{array}{r}\text { No. of } \\
\text { Samples } \\
\end{array}$} & \multicolumn{3}{|c|}{ Dose Rate $(\mathrm{mrad} / \mathrm{yr})^{(\mathrm{a})}$} \\
\hline & & & Maximum & Minimum & Average $^{(b)}$ \\
\hline Above $100-K$ & 1 & 12 & 80 & 62 & $72 \pm 12$ \\
\hline 100-N Trench Springs & 2 & 12 & 660 & 280 & $430 \pm 230$ \\
\hline Opposite 100-0 & 3 & 12 & 69 & 51 & $63 \pm 11$ \\
\hline Locke Island & 4 & 12 & 84 & 69 & $76 \pm 11$ \\
\hline White Bluffs & 5 & 12 & 84 & 66 & $73 \pm 12$ \\
\hline Below 100-F & 6 & 11 & 77 & 58 & $69 \pm 13$ \\
\hline Hanford Powerl ine Crossing & $\lg 7$ & 12 & 88 & 58 & $75 \pm 16$ \\
\hline Hanford Ferry & 8 & 9 & 88 & 55 & $75 \pm 21$ \\
\hline Hanford RR & 9 & 12 & 150 & 100 & $120 \pm 32$ \\
\hline Ringold Island & 10 & 12 & 77 & 66 & $73 \pm 11$ \\
\hline Powerline Crossing & 11 & 12 & 99 & 62 & $82 \pm 20$ \\
\hline Wooded Island & 12 & 12 & 88 & 62 & $76 \pm 21$ \\
\hline
\end{tabular}

(a) Monthly measurements in mrad were converted to equivalent annual dose.

(b) Average \pm two standard deviations is shown for each location. 


\section{RADIOLOGICAL IMPACT OF HANFORD OPERATIONS}

The preceding sections on environmental data collected during 1978 provide information for differentiating between those sources of environmental radiation arising from past or current Hanford operations and those due to worldwide fallout or natural radioactivity. Contributions from Hanford operations were distinguishable from other sources in only two areas. These include the residual levels of long-lived radionuclides, primarily ${ }^{60}$ Co, associated with sediments along t'ine Columbia River islands and shoreline near the Hanford Site, and the very low concentrations of radionuclides in Columbia River water as a result of current $\mathrm{N}$ Reactor operations. The radiological impact of Hanford operations is calculated from the quantity of radionuclides measured in effluents from operating facilities in 1978, and from the residual radionuclides in river sediments from the past operations. A comparison of the estimated impact from Hanford operations with the impacts from other sources of radiation exposure routinely encountered is included in the summary at the end of this section.

\section{RADIOLOGICAL IMPACT FROM 1978 EFFLUENTS}

The radionuclide composition of effluents reported for 1978 by all Hanford contractors is shown in Table 16. Since these quantities of radionuclides, when dispersed in 1 arge volumes of air and water, were generally undetectable in the off-site environment, empirical dose mode $1 \mathrm{~s}(13,14)$ were used to assess the resulting radiological dose impact. These models are considered to provide the best estimate of the dose impact from Hanford operations during 1978. Small differences in the calculated doses may appear from year to year, depending on the quantity and type of effluents and the flow rate of the Columbia River. During 1978, for instance, the river flow was greater than in 1977, hence calculated doses for exposure via river pathways are lower than they were in 1977.

Manual Chapter 0513(15) states that a radiological impact assessment should provide realistic estimates of

- the exposure rate on the site boundary where the maximum exposure rates exist ("fence-post" exposure)

- the maximum dose to an individual member of the public

- the whole-body dose to the entire population within an $80-\mathrm{km}$ (50-mile) radius of the site (person-rem).

The assessment of these impacts for 1978 follows.

\section{Maximum "Fence-Post" Exposure Rate}

Late in 1977 the full Hanford reach of the Columbia River was declared legally accessible to the public. As a result, the river shoreline effectively became the boundary for this portion of the site. In 1978, the "fence-post" was moved to a point on the Columbia River shoreline near $N$ Reactor. Here the exposure to airborne and liquid effluents is maximized. The radiation exposure rate from 1978 effluents was calculated to be $5.3 \times 10^{-4} \mathrm{mR} / \mathrm{hr}$. Short-lived noble gases ( $41_{\mathrm{Ar}}$ and $138 \mathrm{Xe}$ ) in the $\mathrm{N}$ Reactor effluents were the major contributors to this exposure rate.

The exposure rate from accumulations of radionuclides in the soil along the shoreline near $\mathrm{N}$ Reactor exceeds the exposure rate attributable to current effluents and is discussed in a separate portion of this section.

\section{Maximum Individual Dose}

Computation of the maximum individual dose is complicated by several factors: the facilities on the Hanford Site are many miles apart, the effluents contain a variety of radionuclides in gaseous, particulate, and liquid forms, and assumptions must be made as to the living and dietary habits of the maximum individual. The radionuclides shown in Table 16 were used in computing the maximum dose to an individual member of the public for several exposure pathways. 
TABLE 16. Radionuclide Composition of Hanford Effluents for Calendar Year 1978

Radionuclide Half Life

$3 \mathrm{H}(\mathrm{HTO})$
$24 \mathrm{Na}$
$32 \mathrm{p}$
$41_{\mathrm{Ar}}$
$51_{\mathrm{Cr}}$
$54 \mathrm{Mn}$
$56 \mathrm{Mn}$

${ }_{58}^{59} \mathrm{Fe}$

$60 \mathrm{Co}$

$65 \mathrm{Zn}$
76
$\mathrm{As}$

$82 \mathrm{Br}$

$85 \mathrm{~m}_{\mathrm{Kr}}$

$85 \mathrm{kr}$

$87 \mathrm{Kr}$

$88 \mathrm{KrRb}$

${ }^{89} \mathrm{Sr}$

$90 \mathrm{Sr}$

$95 \mathrm{Zr}$

$95 \mathrm{Nb}$

$97 \mathrm{ZrNb}$

99 mMoTc

$103 \mathrm{Ru}$

$106 \mathrm{Ru}$

$122 \mathrm{Sb}$

$124 \mathrm{Sb}$

$125 \mathrm{Sb}$

$132 \mathrm{Te}$

129 I

131

$132 \mathrm{I}$

$133 \mathrm{I}$

$135 \mathrm{I}$

$133 \mathrm{xe}$

$133 \mathrm{~m} \times \mathrm{e}$

$135 \mathrm{xe}$

$138 \times \mathrm{Xe}$

$134 \mathrm{Cs}$

$137 \mathrm{Cs}$

140 La

$141 \mathrm{Ce}$

${ }_{144} \mathrm{CePr}$

$147 \mathrm{Nd}$

$153 \mathrm{Sm}$

$154 \mathrm{Eu}$

$155 \mathrm{Eu}$

$187 \mathrm{~W}$

$220 \mathrm{Rn}$

Ul-Nat.

$239_{\mathrm{Np}}$

238 Pu

$239 \mathrm{pu}$
$12.3 \mathrm{yr} \quad 330$

$15 \mathrm{hr}$

$14.3 \mathrm{~d}$

$1.8 \mathrm{hr}$

$27.8 \mathrm{~d}$

$303 \mathrm{~d}$

$2.6 \mathrm{hr}$

$46 \mathrm{~d}$

$71 \mathrm{~d}$

$5.3 \mathrm{yr}$

$245 \mathrm{~d}$

$26.4 \mathrm{hr}$

$35 \mathrm{hr}$

$4.4 \mathrm{hr}$

$10.8 \mathrm{hr}$

$76 \mathrm{~min}$

$2.8 \mathrm{hr}$

$52.7 \mathrm{~d}$

$27.7 \mathrm{yr}$

$65.5 \mathrm{~d}$

$35 \mathrm{~d}$

$17 \mathrm{hr}$

$66.7 \mathrm{hr}$

$39.5 \mathrm{hr}$

$368 \mathrm{~d}$

$2.8 \mathrm{~d}$

$60.4 \mathrm{~d}$

$2.7 \mathrm{yr}$

$77.7 \mathrm{hr}$

$1.7 \times 10^{7}$

$8.1 \mathrm{~d}$

$2.3 \mathrm{hr}$

$20.3 \mathrm{hr}$

$6.7 \mathrm{hr}$

$5.3 \mathrm{~d}$

$2.3 \mathrm{~d}$

$9.1 \mathrm{hr}$

$17.5 \mathrm{~min}$

$2.1 \mathrm{yr}$

$30.0 \mathrm{yr}$

$12.8 \mathrm{~d}$

$40.2 \mathrm{hr}$

$32.5 \mathrm{~d}$

$284 \mathrm{~d}$

$11.1 \mathrm{~d}$

$46.8 \mathrm{hr}$

$16 \mathrm{yr}$

$1.8 \mathrm{yr}$

$23.9 \mathrm{hr}$

$4 . \overline{4} \times 109 \mathrm{yr}$

$2.3 \mathrm{~d}$

$86.4 \mathrm{yr}$

$2.44 \times 10^{-4} y r$

\begin{tabular}{|c|c|c|c|}
\hline \multicolumn{4}{|c|}{ Effluent ( $\mathrm{C} i$ ) } \\
\hline Liquid & & Gaseous & \\
\hline & 100 Area & 200 Areas & 300 Area \\
\hline
\end{tabular}

$0 . \overline{03}$

$0 . \overline{14}$

0.18

1.2

0.11

0.032

0.96

$--$

$--$

$--$

$--$

$--$

0.40

1.3

0.11

0.16

2.6

0.38

0.57

$0 .-$

0.062
0.17

$2 \times 10^{-6}$

31

0.20

$1.1 \times 10^{5}$

0.046

0.021

3.8

0.022

0.019

0.038

0.012

6.7

0.013

510

$1540^{-}$

1180

0.021

$7.2 \times 10$

0.0078

0.0073

0.011

1.0

0.017

0.060

0.0054

0.003
$3.0 \times 10^{-4}$

0.025

0.47

0.47

4.8

0.95

--

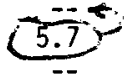

3.1

6.2

91

1.6

2120

$--$

0.031

0.38

4.0

0.035

0.15

0.17

--

$-$

$-$

$-$

$--$

$-$

$\times 10^{-4}$

5040

$8 \times 10^{-4}$

0.0023

0.19

1.1

0.0074

0.057

0.077

0.028

0.032

0.071

0.34

--

$-$

$3.6 \times 10^{-7}$

$2.2 \times 10^{-6}$

inte Areas

-- $\quad 0.046$

$\begin{array}{ll}-- & -- \\ -- & -- \\ -- & = \\ -- & \\ -- & \\ -- & \\ -- & -\end{array}$

$\begin{array}{lll}-- & 14.7 \times 10^{-5}(\mathrm{a})\end{array}$

$\begin{array}{ll}-- & -- \\ -- & --\end{array}$

$\begin{array}{lll}-- & - \\ -- & 440 \\ -- & -\end{array}$

$0 . \overline{83}(b) 0.12 \quad 1.1 \times 10-4(b)$

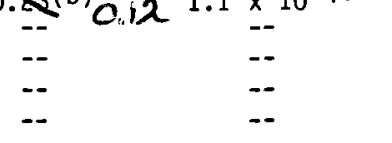

$--\quad \quad-$

$\begin{array}{lll}-- & -1 \\ -- & -1\end{array}$

$\begin{array}{ll}-- & - \\ -- & --\end{array}$

$\begin{array}{ll}-- & -- \\ -- & --\end{array}$

$\begin{array}{ll}-- & - \\ -- & -1\end{array}$

-- $\quad 5.8 \times 10^{-4}$

$-\quad 3.5 \times 10^{-4}$

--

$\begin{array}{ll}-- & -- \\ -- & --\end{array}$

$\begin{array}{ll}-- & -- \\ -- & --\end{array}$

$\begin{array}{ll} & - \\ -- & --\end{array}$

-

$\begin{array}{ll}-- & -- \\ -- & -\end{array}$

-- $\quad-$

$\begin{array}{ll}-- & -- \\ -- & --\end{array}$

--

$\begin{array}{ll}-- & -- \\ -- & --\end{array}$

$\begin{array}{ll}-- & -- \\ -- & --\end{array}$

--

$\begin{array}{ll}-- & 0.009\end{array}$

$\begin{array}{ll}- & 0.009 \\ - & 7.2 \times 10-6-4.0 \times 10^{8}\end{array}$

$0.0023(c)$

--

$2.8 \times 10^{-5}(\mathrm{c})$

(a) Actually reported as mixed activation products. Cobalt-60 was assumed for simplicity and was used in dose calculations.

(b) Actually reported as mixed fission products. Strontium-90 was assumed for simplicity and was used in dose calculations.

(c) Actually reported as gross alpha. Plutonium-239 was assumed for simplicity and was used in dose calculations.

-- Radionuclide not reported in effluent. 
The maximum individual dose calculation for 1978 includes estimates of the dose received from 1) exposure to airborne radionuclides at a location $1.6 \mathrm{~km}$ ( $1 \mathrm{mile}$ ) east of the 300 Area, 2) intake of drinking water obtained from the Columbia River at Richland, 3) consumption of foodstuff irrigated with Columbia River water at Riverview, and 4) aquatic recreation along the Hanford reach of the Columbia River. Shown in Tables 17 and 18 are the results of these calculations for the annual and the 50-yr dose commitment, respectively. The doses shown in these tables are not additive, since it is not possible for a single individual to be exposed to all sources at the same time. Further discussion of the dose from each of these pathways follows.

\section{Airborne Releases}

The maximum doses received offsite as a result of Hanford's airborne effluents in 1978 occurred at a location $1.6 \mathrm{~km}$ east of the 300 Area. Within this area are located the nearest dairy and farming operations in a downwind direction from the Hanford Site. Doses calculated include those received from inhalation of airborne radionuclides and from submersion in the plume for $8766 \mathrm{hr} / \mathrm{yr}$ (continuous occupancy); and that received from exposure to ground contamination for $4383 \mathrm{hr} / \mathrm{yr}$ (one-half of the total exposure time possible). In addition, the dose resulting from ingestion of a variety of foodstuffs (e.g., garden vegetables, milk, etc.) contaminated via dry deposition was calculated because of the foodstuffs grown in that area.

All of the annual doses resulting from exposure to the 1978 airborne effluents were far below Manual Chapter 0524 standards. The calculated annual whole-body dose $(0.08 \mathrm{mrem})$ represents $0.016 \%$ of the standard for the maximum individual in an uncontrolled area. Table 18 shows the 50-yr dose commitment from 1978 airborne effluents.

\section{Drinking Water}

Richland is the first city downstream from the Hanford Site to obtain some of its drinking water from the Columbia River. Tables 17 and 18 show the estimated annual dose and 50-yr dose commitment for an individual who drinks 730 liters (193 gal) of water obtained from the Columbia River. Removal of part of the activity from the river water by the water treatment plant was accounted for in the calculation. This removal factor varies with the radionuclide. (See reference 14 for details.) The calculated maximum annual dose( 0.05 mrem to the thyroid) represents $1.3 \%$ of the Washington State drinking water standard of 4 mrem per year.

\section{Irrigated Foodstuffs}

The Riverview Area is the first area downstream from the Hanford Site that is extensively irrigated with Columbia River water. Shown in Tables 17 and 18 are the maximum annual dose and 50-yr dose commitments for an individual who consumes foodstuffs irrigated with Columbia River water, livestock raised on irrigated pasture, and a variety of other farm products whose culture involves Columbia River water. Many of the assumptions made about the maximum individual's diet, the crops irrigated, etc., are described in Appendix $D$. The calculated maximum annual dose $(0.16$ mrem to the thyroid) represents $0.01 \%$ of the Manual Chapter 0524 standard for the maximum individual in an uncontrolled area.

\section{Aquatic Recreation}

The Columbia River is used extensively for recreation. Estimates of the dose received from recreational activities, shown in Tables 17 and 18, are based on an individual who annually spends $500 \mathrm{hr}$ along the shoreline, $100 \mathrm{hr}$ swimming, and $100 \mathrm{hr}$ boating, and who consumes $40 \mathrm{~kg}$ ( $88 \mathrm{lb}$ ) of fish from the Hanford reach of the Columbia River. All of the radionuclides released to the river were considered in the dose est $i-$ mates. (Appendix D contains additional details on this calculation.) The calculated maximum annual dose $(0.05 \mathrm{mrem}$ to the thyroid) represents $0.003 \%$ of the Manua 1 Chapter 0524 standard for the maximum individual in an uncontrolled area.

\section{Population Dose}

Doses to the population within an $80-\mathrm{km}$ (50-mile) radius of the Hanford Site were computed for all of the radionuclides listed in Table 16. Since the affected population differs with each environmental pathway considered, a dose estimate is provided for each pathway-population combination. In addition, a population dose was calculated for each major operating area since a different population distribution exists for each.

Summarized in Table 19 are the estimated population doses resulting from 1978 effluents to the Columbia River. The drinking water obtained from the Columbia River downstream from Hanford produces the largest population dose from liquid effluents. 
TABLE 17. Annual Dose to the Maximum Individual

from Effiuents Released During 1978

Environmental

Pathway

Airborne(c)

Drinking Water

Irrigated Foodstuff $<0.01$

Aquatic Recreation $(d)<0.01$

(a) The doses shown are not strictly additive. The dose received is dependent on the location and assumed living habits of the hypothetical maximum individual. The location of the maximum individual is different for each pathway shown; in some cases these locations are separated by many miles (see text).

(b) Gastrointestinal tract (lower large intestine).

(c) Includes dose contributions from inhalation, submersion, ingestion of foodstuffs contaminated by airborne deposition, and exposure to ground contamination.

(d) Includes consumption of fish from the Columbia River.

TABLE 18. 50-year Dose Commitment for the Maximum Individual from Effluents Released During 1978

Environmental

Pathway

Airborne(c)

Drinking Water

Whole Dose (mrem) (a)

Irrigated Foodstuff $<0.01$

$$
0.11
$$

0.08

GI(b)

Thyroid

Bone

Lung

Aquatic Recreation $(d)<0.01$

$--\quad<0.01<0.01$

$<0.01$

0.22

$<0.01$

0.01

0.05

$<0.01$

$<0.01$

0.04

$<0.01$

0.16

0.14

$<0.01$

0.02

$<0.01$

0.05

0.06

$<0.01$

(a) The doses shown are not strictly additive. The dose received is dependent on the location and assumed living habits of the hypothetical maximum individual. The location of the maximum individual is different for each pathway shown; in some cases these locations are separated by many miles (see text).

(b) Gastrointestinal tract (lower large intestine).

(c) Includes dose contributions from inhalation, submersion, ingestion of foodstuffs contaminated by airborne deposition, and exposure to ground contamination.

(d) Includes consumption of fish from the Columbia River. 


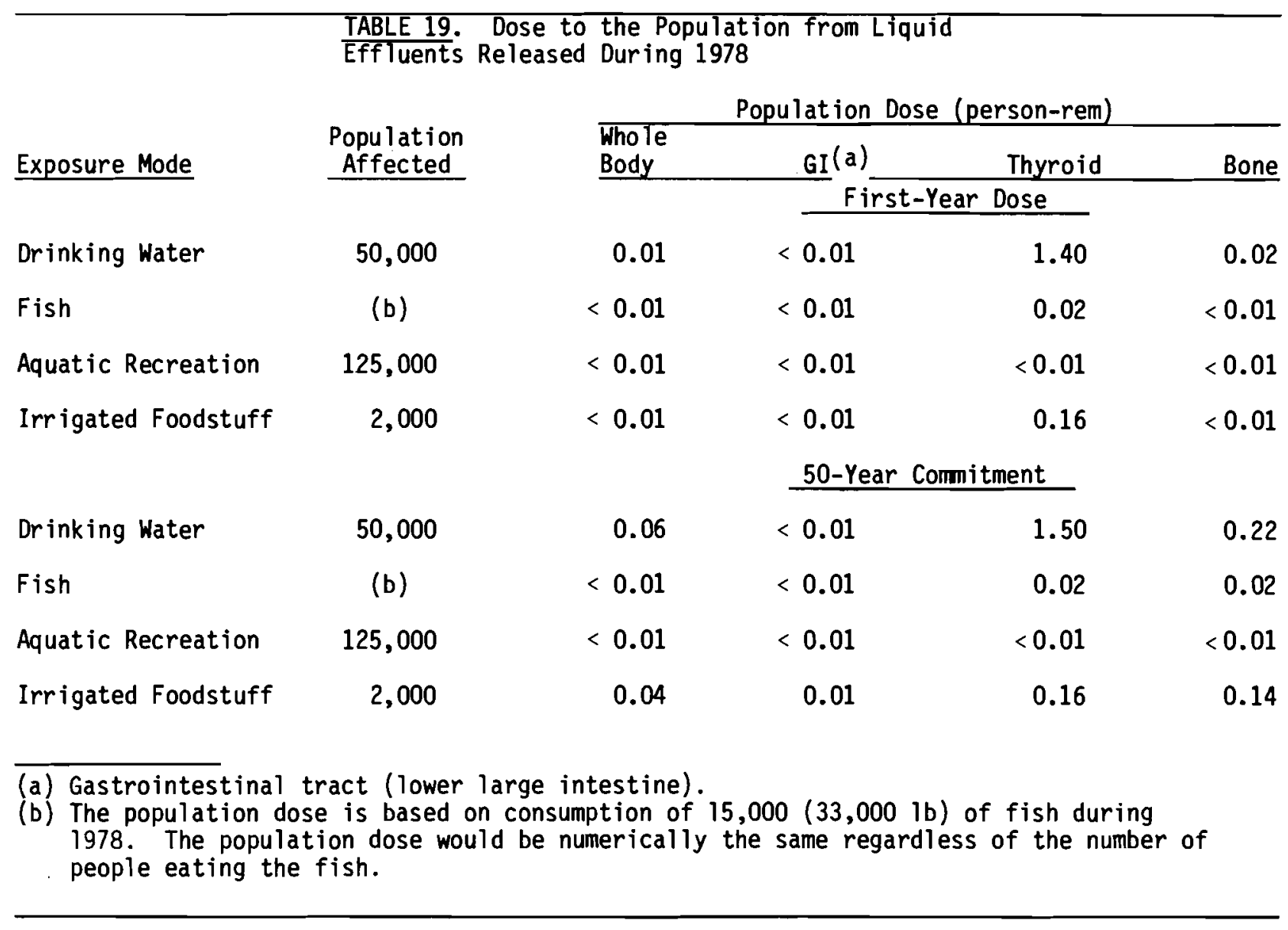

TABLE 20. Dose to the Population from Airborne Effluents Released During 1978

\begin{tabular}{|c|c|c|c|c|c|c|}
\hline \multirow[b]{2}{*}{$\begin{array}{l}\text { Effluent Release } \\
\text { Point }\end{array}$} & \multirow[b]{2}{*}{$\begin{array}{c}\text { 80-Kilometer } \\
\text { Population }\end{array}$} & \multicolumn{5}{|c|}{ Population Dose (person-rem) } \\
\hline & & \multirow[t]{2}{*}{$\begin{array}{l}\text { Whole } \\
\text { Body }\end{array}$} & GI (a) & Thyroic & Bone & Lung \\
\hline & & & \multicolumn{3}{|c|}{ First-Year Dose } & \\
\hline 100-N Area & 236,000 & 1.5 & 1.5 & 3.1 & 1.5 & 1.7 \\
\hline 200 Areas & 258,000 & 0.01 & $<0.01$ & $<0.01$ & $<0.01$ & 0.02 \\
\hline \multirow[t]{2}{*}{300 Area } & 171,000 & $<0.01$ & $<0.01$ & 0.25 & $<0.01$ & 0.10 \\
\hline & & & \multicolumn{3}{|c|}{ 50-Year Commitment } & \\
\hline 100-N Area & 236,000 & 1.5 & 1.5 & 3.2 & 1.5 & 1.7 \\
\hline 200 Areas & 258,000 & 0.06 & $<0.01$ & $<0.01$ & 0.28 & 0.06 \\
\hline 300 Area & 171,000 & $<0.01$ & $<0.01$ & 0.41 & 0.03 & 0.11 \\
\hline
\end{tabular}

(a) Gastrointestional tract (lower large intestine). 
Shown in Table 20 are the computed doses to the population within an 80-km (50-mile) radius of the 100-N Area, 200 Areas, and 300 Area, from airborne effluents. Also shown are the estimated population groups affected by the effluents. Of the three operational areas, the 100-N Area has releases resulting in the largest population dose.

RADIOLOGICAL IMPACT FROM PAST HANFORD OPERATIONS

Previous sections of this report showed that, in general, any Hanford contributions to the levels of radiation observed in the environment were indistinguishable from preexisting levels attributed to worldwide fallout or natural causes. Exceptions to these findings were the detection of a few radionuclides released from $\mathrm{N}$ Reactor to the Columbia River at concentrations less than $1 \%$ of the most restrictive guidelines of Manual Chapter 0524, and the continued presence of a few long-lived radionuclides, notably ${ }^{60} \mathrm{Co}$, along the Columbia River islands and shoreline near the Hanford Site. The radionuclides attributable to $\mathrm{N}$ Reactor were included in Table 16 and in the evaluation of the dose impact just discussed. The impact of the activity on the Columbia River islands and shoreline is evaluated here.

Slightly contaminated soil along the shoreline in the vicinity of $N$ Reactor produces a measured maximum "fence-post" exposure rate of about $0.075 \mathrm{mR} / \mathrm{hr}$. Access to the area of maximum exposure rate is possible only if boaters trespass on the Hanford Site shore.

Shoreline sediments containing 60 Co would contribute to the maximum individual dose in proportion to the amount of time the individual spent in the area and exactly where it was spent, since the distribution of activity is highly variable. An individual spending $500 \mathrm{hr} / \mathrm{yr}$ at the location of highest observed offsite exposure rate, as determined by thermoluminescent dosimeter measurement, would receive an annual dose of about $0.4 \mathrm{mrem}$ due to $60 \mathrm{Co}$; this represents less than $0.1 \%$ of the 500 mrem standard from Manual 1 Chapter 0524 for uncontrolled areas.

The contributions of the ${ }^{60} \mathrm{Co}$ in the shoreline sediments to the population dose computed for 1978 are insignificant because of the low levels of radioactivity, the remoteness of the shorelines, and the small number of people potentialiy affected.

\section{IMPACT SUMMARY}

The maximum "fence-post" exposure rate for 1978 , about $0.075 \mathrm{mR} / \mathrm{hr}$, occurred at a point on the Hanford shoreline of the Columbia River near $\mathbf{N}$ Reactor. Accumulations of radionuclides in the soil at this location were responsible for most of this exposure rate.

The maximum annual whole-body dose to an individual member of the public from 1978 effluents is estimated to be less than 0.1 mrem, including contributions from airborne, drinking water, irrigated foodstuff, and aquatic recreation pathways. The annual dose potentially received by any single organ (skin, GI, thyroid, bone, and lung) of the maximum individual from all pathways is estimated to be less than 0.5 mrem. These doses represent $0.02 \%$ of the maximum annual wholebody dose standard and $0.03 \%$ of the maximum single organ dose standard in Manual Chapter 0524 .

Airborne effluents from the Hanford Site's three operating areas resulted in an annual whole-body dose to the population within an $80-\mathrm{km}$ (50-mile) radius of Hanford of about 1.5 person-rem. Liquid effluents during 1978 contributed very little (about 0.01 personrem) to the total population dose because of the limited population affected. The total population dose is equivalent to an annual per capita whole-body dose of about 0.006 mrem (1.5 person-rem/250,000 people).

These dose estimates can be compared with doses from other routinely encountered sources of radiatjon such as natural background radiation, (16) medical diagnostic procedures, (16) and a 5-hr commercial jet flight.(11) Compared graphically in Figure 12 are the average doses from these sources and the maximum individual and average per capita whole-body doses from Hanford operations for 1978. The estimated population dose of 1.5 person-rem may also be compared with the approximately 25,000 person-rem received annually by the same population from background radiation.

Hanford contributions to both individual and population radiation exposure clearly represent a very small fraction of the dose received from other sources. Moreover, the maximum dose potentially received from natural background radiation, diagnostic medical procedures, and commercial jet flights could be much greater than the values shown, depending on an individual's life-style. $(11,16)$ Thus the dose contribution to the maximum individual from Hanford operations is much less than the variability in other doses received by people with different lifestyles. 


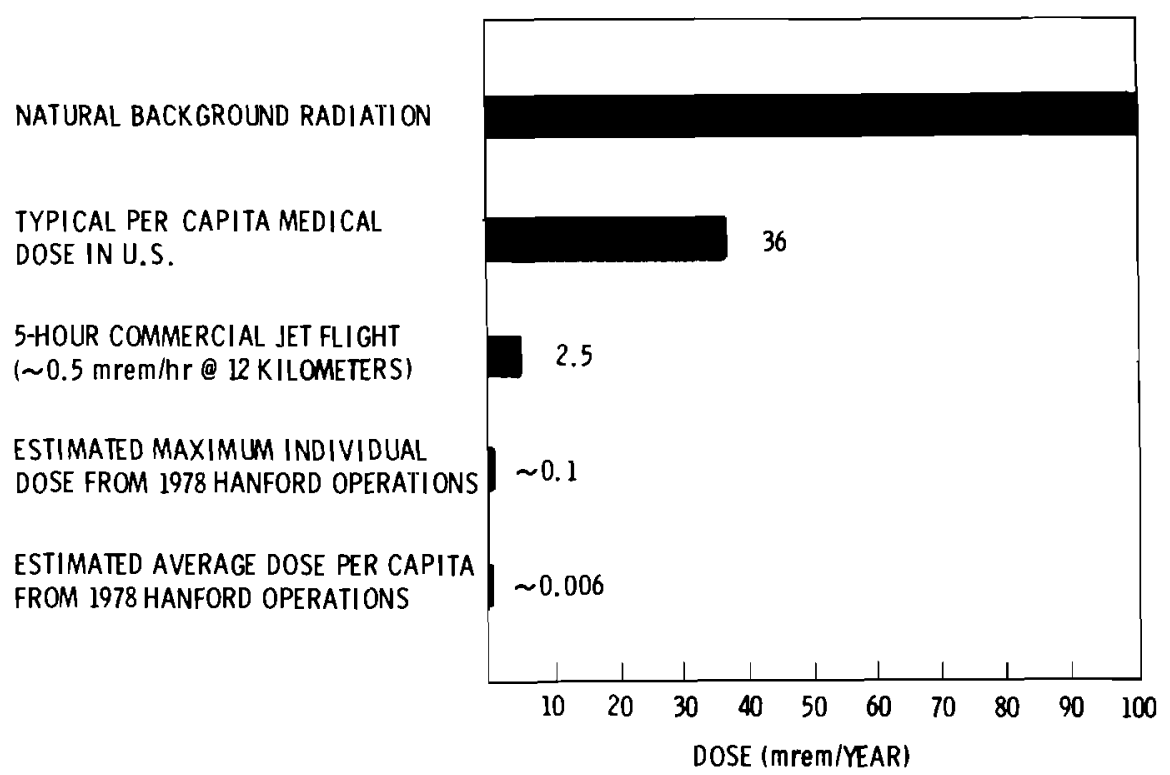

FIGURE 12. Comparative Doses Received from Various Radiation Sources 
1. P. A. Eddy, Environmental Monitoring Report on the Status of Ground Water Beneath the Hanford Site January December 1978. PNL-2899, Pacific Northwest Laboratory, Rich land, WA 99352, April 1979.

2. P. J. Blumer, D. A. Myers and J. J. Fix, Master Schedule for $\mathrm{CY}-1978$ Hanford Environmental Surveillance Routine Program. PNL-2432, Pacific Northwest Laboratory, Richland, WA 99352, December 1977.

3. J. R. Houston and P. J. Blumer, Environmental Surveillance at Hanford for CY-1977. BNWL-2614, Pacific Northwest Laboratory, Richland, WA 99352, April 1978.

4. U.S. Energy Research and Development Administration, Manual Chapter 0524, "Standards for Radiation Protection," with Appendix. U.S. Energy Research and Development Administration, Washington, DC, October 1973.

5. Water Quality Standards. Washington State Department of Ecology, December 1977.

6. "Natural Primary and Secondary Ambient Air Quality Standards." Federal Regulations, 40 CFR 50, Environmental Protection Agency, January 1973.

7. "TGS-ANSA Method for the Determination of Nitrogen Dioxide in the Atmosphere." Method No. EQN-1277-028, U.S. Environmental Protection Agency, Environmental Monitoring Support Laboratory, Department E, Research Triangle Park, North Carolina.

8. R. T. Jaske and M. R. Synoground, Effect of Hanford Plant Operations on the Temperature of the Columbia River, 1964 to Present. BNWL-1345, Pacific Northwest Laboratory, Richland, WA 99352, November 1970 .
9. Federal Radiation Council, Background Material for the Development of RadiaEion Protection Standards. Report \#5, Federal Radiation CounciT, Washington, DC, July 1964.

10. J. J. Fix and M. L. Miller, The Hanford Environmental $\mathrm{CaF}_{7}: \mathrm{Mn}$ ThermoTuminescent Dosimeter. PNL-2489, Pacific Northwest Laboratory, Richland, WA 99352, March 1978.

11. National Council on Radiation Protection, Natural Background Radiation in the United States. NCRP Report No. 45, National CounciT on Radiation Protection, Washington, DC, 1975.

12. W. J. Tipton, An Aerial Radiological Survey of the U.S. Energy Research and Development Administration's Hanford Reservation. EGG-1183-1661, EG\&G, Inc., Las Vegas, NV, April 1975.

13. J. R. Houston, D. L. Strenge and E. C. Watson, DACRIN - A Computer Code for Calculating Organ Dose from Acute or Chronic Radionuclide Inhalation. BNWL-B-389, Pacific Northwest Laboratory, Richland, WA, 99352, August 1975.

14. D. A. Baker, G. R. Hoenes and J. K. Soldat, FOOD - An Interactive Code to Calculate Internal Radiation Doses from Contaminated Food Products. BNWL-SA5523, Pacific Northwest Laboratory, Richland, WA 99352, February 1976.

15. U.S. Energy Research and Development Administration, Manual Chapter 0513, "Effluents and Environmental Monitoring and Reporting." U.S. Energy Research and Development Administration, Washington, DC, February 1974.

16. U.S. Environmental Protection Agency, Estimates of Ionizing Radiation Doses in the United States, 1960-2000. ORP/CSD 72-1, Rockvilie, MD, August 1972. 
APPENDIX A

APPLICABLE STANDARDS 


\section{APPENDIX A}

\section{APPLICABLE STANDARDS}

Operations at the Hanford Site must conform to a variety of federal and state standards designed to ensure the radiological, chemical, biological, and physical quality of the environment for either aesthetic or public health considerations. The state of Washington has promulgated water gyality standards for the Columbia River. (5) of interest to Hanford operations is the designation of the Hanford reach of the Columbia
River as $C$ lass $A$ or excellent. This designation requires that the water be usable for substantially all needs including drinking water, recreation, and wildlife. Class $A$ water standards are summarized in Table A.1. Air quality standards have been promulgated by the Environmental Protection Agency $(E P A)(6)$ and are summarized in Table A.2.

TABLE A.1. Washington State Water Qualjty Standards for the Hanford Reach of the Columbia River(5)

\section{CLASS A WATER CHARACTERISTIC}

Meets or exceeds requirements for all uses.

USES

Include but not limited to:

Water supply--domestic, industrial, agricultural

Wildlife habitat, stock watering

Genera 1 recreation and aesthet ic enjoyment

Commerce and navigation

Fish and shellfish reproduction, rearing and harvesting

WATER QUALITY STANDARDS

Parameter

Fecal coliform organism

Dissolved oxygen

Temperature

$\mathrm{pH}$

Turbidity

Toxic, radioactive, or

deleterious materials

Aesthetic value
Permissible Levels

1) $\leq 100$ organisms $/ 100 \mathrm{ml}$ (median)

2) $\leq 10 \%$ of samples may exceed 200 organisms $/ 100 \mathrm{ml}$

$>8 \mathrm{mg} / 1$

1) $\leq 18^{\circ} \mathrm{C}\left(64^{\circ} \mathrm{F}\right)$ due to human activities

2) Increases not to exceed $28 /(T+27)$, where $T=$ highest existing temperature in ${ }^{\circ} \mathrm{C}$ outside of mixing zone

1) $6.5-8.5$ range

2) $<0.5$ unit induced variation

$\leq 5 \mathrm{JTU}^{(\mathrm{a})}$ over background turbidity

Concentrations shall be below those of public health significance, or which cause acute or chronic toxic conditions to the aquatic biota, or which may adversely affect any water use.

Shall not be impaired by the presence of materials or the ir effects, excluding those of natural origin, which of fend the senses of sight, smell, touch or taste.

(a) JTU = Jackson Turbidity Units - Standard Candle 
TABLE A.2. Air Quality Standards

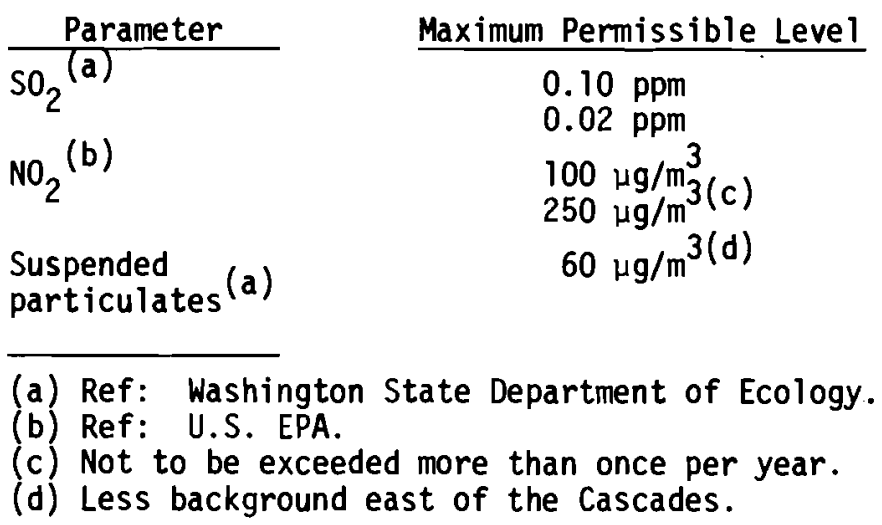

Environmental radiation protection standards are published in Manual Chapter 0524, "Standards for Radiation Protection." (4) These standards are based on guidelines originally recommended by the Federal Radiation Council (FRC) and other scientific groups such as the International Commission on Radiological Protection (ICRP) and the National Commission on Radiation Protection and Measurements (NCRP). The standards govern exposures to ionizing radiation for DOE and DOE contractor personnel and for members of the public who may be exposed to ionizing radiation resulting from DOE and DOE contractor operations. Several concentration guides for air and water are listed in Table A.3.

Copies of these regulations may be obtained from the following organizations:

- State of Washington Department of Eco logy Olympia, WA 98504

- U.S. Environmental Protection Agency, Region 10 1200 Sixth Avenue Seattle, WA 98101

- U.S. Department of Energy Richland Operations Office Richland, WA 99352
TABLE A.3. Radionuclide Concentration Guides(a)

\begin{tabular}{|c|c|c|}
\hline Radionuclide & $\left(10^{-9} \mu \mathrm{Ci} / \mathrm{ml}\right)$ & $\left(10^{-\mathbf{x}_{\mu \mathrm{C}}^{\text {Air }}}\right.$ \\
\hline Alpha & 30 & 0.02 \\
\hline $3_{H}$ & $3,000,000$ & 200,000 \\
\hline${ }^{54} \mathrm{Mm}$ & 100,000 & 1,000 \\
\hline L & $2,000,000$ & 80,000 \\
\hline${ }^{60} \mathrm{Co}$ & 30,000 & 300 \\
\hline${ }^{65} \mathrm{Zn}$ & 100,000 & 2,000 \\
\hline${ }^{90} \mathrm{sr}$ & 300 & 30 \\
\hline${ }^{95}$ Zrib & 60,000 & 1,000 \\
\hline${ }^{106} \mathrm{Rn}_{\mathrm{n}}$ & 10,000 & 200 \\
\hline $13 I_{I}$ & 300 & 100 \\
\hline${ }^{137} \mathrm{Cs}$ & 20,000 & 500 \\
\hline 140 BaLa & 20,000 & 500 \\
\hline & 10,000 & 200 \\
\hline${ }^{239} \mathrm{Pu}$ & 5,000 & 0.06 \\
\hline
\end{tabular}

(a) Obtained from Manual Chapter 0524, Table II. Host restrictive guide assumed. 
APPENDIX B

ANALYTICAL PROCEDURES 


\section{APPENDIX B}

\section{ANALYTICAL PROCEDURES}

\section{AIR SAMPLES}

Alpha-, Beta-, and Gamma-Emitting Radionuclides are measured by a direct count of the asbestos paper filter; alpha on a low background gas flow proportional counter, beta on a gas flow proportional counter, and gamma on a $23-\mathrm{cm} \times 23-\mathrm{cm}(9-i n . \times 9-i n.) \mathrm{NaI}$ (T1) well detector with a multichannel gammaray spectrometer.

Strontium-89, 90 are collected on filter paper and determined by leaching the filters with nitric acid, precipitating with fuming nitric acid, scavenging with barium chromate, precipitating as a carbonate, transferring to a stainless steel planchet, and counting with a gas flow proportional counter.

Plutonium is leached from the filter paper with fuming nitric acid and passed through an anion exchange resin. The resin column is eluted with $0.4 \underline{\mathrm{N}} \mathrm{HNO}_{3}-0.01 \underline{\mathrm{N}} \mathrm{HF}$ and the plutonium in the eluate is electrodeposited on a stainless steel disk, exposed to nuclear track film, and then counted.

Tritium in air as HTO is determined by collecting the water vapor with silica gel. The water vapor is removed by heat and vacuum and collected in a freeze trap. The tritium content of the water vapor is determined with a liquid scintillation spectrometer.

Iodine-131 is collected on activated charcoal which is then counted in the well of a 23-cm $\times 23-\mathrm{cm}(9-i n . \times 9-i n.) \mathrm{NaI}(\mathrm{Tl})$ well detector.

\section{WATER SAMPLES}

Beta-Emitting Radionuclides are measured by a direct count of dried residue.

Uranium and Plutonium (Total Alpha) are extracted into ether from strong nitric acid. The ether phase is evaporated off and the residue plated on a stainless steel planchet and counted with a low-background gas flow proportional counter.

Gamma-Emitting Radionuclides are determined by a direct count of $500 \mathrm{ml}$ of sample in the well of a $23-\mathrm{cm} \times 23-\mathrm{cm}(9-\mathrm{in} . \times$ 9-in.) $\mathrm{NaI}(\mathrm{Tl})$ well detector with a multichannel gamma-ray spectrometer.
Strontium-90 in large-volume water samples is precipitated with fuming nitric acid, scavenged with barium chromate, precipitated as a carbonate, transferred to a stainless steel planchet, and beta-counted with a lowlevel beta proportional counter. After a 15-day period the yttrium-90 daughter is separated and counted with a low-level beta proportional counter.

Tritium is measured in distilled water samples with a liquid scintillation spectrometer.

Filter-Resin Samples are analyzed for gamma-emitting radionuclides using a GeLi detector with a multichannel ganma-ray spectrometer. Aliquots of the samples are andyzed by neutron activation analys is for 129 I and by chemical separation and alpha spectrometric means for plutonium.

MILK

Garma-Emitting Radionuclides are measured by a direct count of the sample in the well of a $23-\mathrm{cm} \times 23-\mathrm{cm}(9-\mathrm{in} . \times 9-$ in.) $\mathrm{NaI}(\mathrm{TI})$ detector.

Iodine-131 is removed from milk with anion exchange resin, $\mathrm{Cl}^{-}$form. The iodine is leached off the resin with sodium hypochlorite, precipitated as palladium chloride, and beta-counted with a low-background beta counter.

Strontium-90 is removed by drying, wet ashing, precipitating with fuming nitric acid, scavenging with barium chromate, precipitating as a carbonate, and transferring to a stainless steel planchet for beta counting.

\section{FARM PRODUCE}

Garma-Emitting Radionuclides are determined by a direct count of the sample in the well of a $23-\mathrm{cm} \times 23-\mathrm{cm}(9-$ in. $\times 9-$ in. $) \mathrm{NaI}$ (TI) well detector.

Plutonium analyses are made like those for air samples after drying, ashing in a furnace, and wet ashing with nitric acid.

Uranium analyses are made like those for water samples after drying, ashing in a furnace, and wet ashing with nitric acid. 
Strontium-90 analyses are made like those for air samples after the pretreatment described for uranium and plutonium.

\section{VEGETATION}

Uranium, Plutonium, Strontium, and GammaEmitting Radionuclides are determined using the procedures described for farm produce.

$\underline{\text { SOIL }}$

Gamma-Emitting Radionuclides are analyzed by placing approximately 500 grams of sample into a marinelli beaker and counting on a lithium-drifted germanium detector, with a multichannel pulse height analyzer.
Plutonium and Strontium-90 are measured when the soil is dried, mixed thoroughly, leached with a mixture of nitric and hydrochloric acids, and then passed through an ion exchange resin in $8 \mathrm{~N}$ nitric acid.

The nitric acid retains strontium and other metal ions. This phase is precipitated with fuming nitric acid, scavenged with barium chromate, precipitated as a carbonate, and transferred to a stainless steel planchet. The ${ }^{90} \mathrm{Sr}$ sample is counted with a low-background beta proportional counter.

The plutonium is eluted from the resin column with $0.4 \underline{\mathrm{N}} \mathrm{HNO}_{3}-0.01 \underline{\mathrm{N}} \mathrm{HF}$ and electrodeposited on a stainless steel disk for alpha spectrometric analyses. 
APPENDIX C

\section{QUALITY ASSURANCE}


Several methods are used to assure that the data collected each year are representative of actual concentrations in the environment. First, extensive environmental data are collected to eliminate an unrealistic reliance on only a few results. Second, newly collected data are compared with historical data for each environmental medium to assure that current values are consistent with previous results. This allows for timely investigation of any unusual result. Third, measurements are collected using identical methods, near to and far from the Hanford Site, as well as upstream and downstream on the river, to provide for identification of any net difference that may be attributable to Hanford operations. These procedures, in conjunction with a program to demonstrate the accuracy of radiochemical analyses, assure that the data accurately represent environmenta 1 conditions.

\section{ANALYTICAL LABORATORY QUALITY ASSURANCE}

The majority of the routine radioanalyses for the Hanford environmental surveillance program are performed by the United States Testing Company in Richland, Washington. This laboratory maintains an internal quality assurance program that involves routine calibration of counting instruments, daily source and background counts, routine yield determinations of radiochemical procedures, replicate analyses to check precision, and analyses of reagents to assure purity of all chemicals. The accuracy of radionuclide determination is assured through the use of standards traceable to the National Bureau of Standards, when available. The laboratory also participates in laboratory intercomparison programs conducted by the Environmental Measurements Laboratory (EML) and the Environmental Protection Agency (EPA). In these programs, a number of different environmental media (water, milk, air filters, and foodstuffs) containing one or more radionuclides in known amounts are prepared and distributed to participating laboratories. Replicate analyses are performed on each sample and the results forwarded to the sponsoring laboratory for comparison with known values and with the results from other laboratories. These programs enable a laboratory to demonstrate that it is capable of performing precise, accurate analyses.

Sumarized in Table $C .1$ is a comparison of United States Testing Company, EPA and EML results. The EML and EPA results, while not the true values, are the mean of replicate analyses and are used as the reference values in the programs.

\section{QUALITY ASSURANCE IN DOSE CALCULATIONS}

Assurance of the dose calculation quality is provided in several ways. First, since doses are similar from year to year, a comparison is made against past calculated doses and any differences are validated. Second, all computed doses are double checked by the originator and by an independent third party who also checks all input data and assumptions used in the calculation. Third, information necessary to perform all of the calculations is fully documented. Synopses of the information for the 1978 calculations are shown in Tables C.2 - C.5. 
TABLE C.1. Summary of Laboratory Intercomparison Results for 1978

\begin{tabular}{|c|c|c|c|c|c|}
\hline \multirow[b]{2}{*}{$\begin{array}{l}\text { Sample } \\
\text { Medium }\end{array}$} & \multirow[b]{2}{*}{ Radionuclide } & \multicolumn{2}{|c|}{ EML } & \multicolumn{2}{|c|}{$E P A^{(a)}$} \\
\hline & & $\begin{array}{l}\text { Number of } \\
\text { Analyses }\end{array}$ & $\begin{array}{l}\text { Average Ratio(b) } \\
\text { UST to EML } \\
\end{array}$ & $\begin{array}{l}\text { Number of } \\
\text { Samples }\end{array}$ & $\begin{array}{l}\text { Average Ratio, } \\
\text { UST to EPA } \\
\text { U }\end{array}$ \\
\hline \multirow[t]{16}{*}{ Air } & Alpha & & & 3 & $0.87 \pm 0.07$ \\
\hline & Beta & & & 3 & $0.96 \pm 0.04$ \\
\hline & ${ }^{22} \mathrm{Na}$ & 4 & $1.12 \pm 0.06$ & & \\
\hline & ${ }^{54} \mathrm{Mn}$ & 4 & $1.22 \pm 0.08$ & & \\
\hline & ${ }^{57} \mathrm{Co}$ & 6 & $1.68 \pm 0.52$ & & \\
\hline & ${ }^{60} \mathrm{Co}_{0}$ & 4 & $1.20 \pm 0.05$ & & \\
\hline & ${ }^{65} \mathrm{Zn}$ & 4 & $1.15 \pm 0.08$ & & \\
\hline & ${ }^{89} \mathrm{Sr}$ & 2 & $1.27 \pm 0.06$ & & \\
\hline & ${ }^{90} \mathrm{Sr}$ & 8 & $0.97 \pm 0.05$ & 3 & $0.92 \pm 0.05$ \\
\hline & ${ }^{106} \mathrm{Ru}$ & 2 & $2.70 \pm 0.08$ & & \\
\hline & $125 \mathrm{Sb}$ & 2 & $2.24 \pm 0.03$ & & \\
\hline & ${ }^{134} \mathrm{Cs}$ & 2 & $2.20 \pm 0.07$ & & \\
\hline & ${ }^{137} \mathrm{Cs}$ & 6 & $1.31 \pm 0.09$ & 3 & $0.99 \pm 0.02$ \\
\hline & ${ }^{144} \mathrm{Ce}$ & 4 & $1.63 \pm 0.06$ & & \\
\hline & ${ }^{238} \mathrm{Pu}$ & 2 & $1.04 \pm 0.18$ & & \\
\hline & ${ }^{239} \mathrm{Pu}$ & 5 & $1.33 \pm 0.50$ & & \\
\hline \multirow[t]{20}{*}{ Water } & Alpha & & & 5 & $0.97 \pm 0.21$ \\
\hline & Beta & & & 5 & $1.12 \pm 0.23$ \\
\hline & ${ }^{3} \mathrm{H}$ & 7 & $1.35 \pm 0.31$ & 5 & $1.27 \pm 0.17$ \\
\hline & ${ }^{22} \mathrm{Na}$ & 2 & $1.08 \pm 0.01$ & & \\
\hline & ${ }^{51} \mathrm{Cr}$ & & & 3 & $1.10 \pm 0.03$ \\
\hline & ${ }^{54} \mathrm{Mn}$ & 6 & $0.97 \pm 0.19$ & & \\
\hline & ${ }^{57} \mathrm{Co}$ & 2 & $0.92 \pm 0.06$ & & \\
\hline & ${ }^{58} \mathrm{Co}$ & 4 & $0.97 \pm 0.07$ & & \\
\hline & ${ }^{60} \mathrm{Co}$ & 7 & $1.01 \pm 0.10$ & 5 & $1.03 \pm 0.09$ \\
\hline & ${ }^{65} \mathrm{Zn}$ & & & 5 & $0.96 \pm 0.08$ \\
\hline & ${ }^{89} \mathrm{Sr}$ & & & 3 & $1.14 \pm 0.12$ \\
\hline & ${ }^{90} \mathrm{Sr}$ & 7 & $0.91 \pm 0.13$ & 3 & $1.01 \pm 0.21$ \\
\hline & ${ }^{106} \mathrm{Ru}$ & & & 4 & $0.92 \pm 0.12$ \\
\hline & ${ }^{134} \mathrm{Cs}$ & & & 5 & $0.99 \pm 0.09$ \\
\hline & ${ }^{137} \mathrm{Cs}$ & 7 & $1.05 \pm 0.24$ & 3 & $1.08 \pm 0.06$ \\
\hline & ${ }^{144} \mathrm{Ce}$ & 4 & $1.07 \pm 0.09$ & & \\
\hline & ${ }^{226} \mathrm{Ra}$ & & & 2 & $0.75 \pm 0.09$ \\
\hline & ${ }^{228} \mathrm{Ra}$ & & & 2 & $1.25 \pm 0.18$ \\
\hline & $\begin{array}{l}\mathrm{U} \\
239\end{array}$ & 7 & $1.13 \pm 0.37$ & & \\
\hline & ${ }^{239} \mathrm{Pu}$ & & & 1 & 1.03 \\
\hline
\end{tabular}

(a) Each sample is analyzed in triplicate.

(b) Average \pm standard deviation of the average. 
TABLE C.1. (Contd)

\begin{tabular}{|c|c|c|c|c|c|}
\hline \multirow[b]{2}{*}{$\begin{array}{l}\text { Sample } \\
\text { Medium } \\
\end{array}$} & \multirow[b]{2}{*}{ Radionuclide } & \multicolumn{2}{|c|}{ EML } & \multicolumn{2}{|c|}{$E P A^{(a)}$} \\
\hline & & $\begin{array}{l}\text { Number of } \\
\text { Analyses }\end{array}$ & $\begin{array}{l}\text { Average Ratio(b) } \\
\text { UST to EML } \\
\end{array}$ & $\begin{array}{l}\text { Number of } \\
\text { Samples }\end{array}$ & $\begin{array}{l}\text { Average Ratio, } \\
\text { UST to EPA } \\
\end{array}$ \\
\hline \multirow[t]{7}{*}{ Soil } & $40_{K}$ & 2 & $0.95 \pm 0.24$ & & \\
\hline & ${ }^{90} \mathrm{Sr}$ & 7 & $1.26 \pm 0.47$ & & \\
\hline & ${ }^{137} \mathrm{Cs}$ & 3 & $0.94 \pm 0.06$ & & \\
\hline & ${ }^{226} \mathrm{Ra}$ & 1 & 0.64 & & \\
\hline & U & 2 & $0.82 \pm 0.42$ & & \\
\hline & ${ }^{238} \mathrm{Pu}$ & 3 & $4.4 \pm 6.4$ & & \\
\hline & ${ }^{239} \mathrm{Pu}$ & 3 & $0.71 \pm 0.14$ & 1 & 0.84 \\
\hline \multirow[t]{6}{*}{ Vegetation } & $40_{K}$ & 3 & $0.80 \pm 0.10$ & & \\
\hline & ${ }^{60} \mathrm{Co}$ & 2 & $2.73+2.69$ & & \\
\hline & ${ }^{90} \mathrm{Sr}$ & 3 & $0.87 \pm 0.26$ & & \\
\hline & ${ }^{137} \mathrm{Cs}$ & 3 & $0.90 \pm 0.05$ & & \\
\hline & U & 1 & 1.02 & & \\
\hline & ${ }^{239} \mathrm{Pu}$ & 2 & $2.31 \pm 2.55$ & & \\
\hline \multirow[t]{7}{*}{ Tissue } & $40_{K}$ & 2 & $0.57 \pm 0.05$ & & \\
\hline & ${ }^{60} \mathrm{Co}$ & 1 & 2.00 & & \\
\hline & ${ }^{90} \mathrm{Sr}$ & 3 & $0.75 \pm 0.31$ & & \\
\hline & ${ }^{137} \mathrm{Cs}$ & 2 & $0.98 \pm 0.11$ & & \\
\hline & ${ }^{226} \mathrm{Ra}$ & 1 & 0.66 & & \\
\hline & ${ }^{238} \mathrm{Pu}$ & 1 & 4.4 & & \\
\hline & ${ }^{239} \mathrm{Pu}$ & 1 & 1.63 & & \\
\hline \multirow[t]{4}{*}{ Milk } & $40_{K}$ & & & 1 & 1.67 \\
\hline & ${ }^{89} \mathrm{Sr}$ & & & 2 & $0.95 \pm 0.01$ \\
\hline & ${ }^{90} \mathrm{Sr}$ & & & 2 & $0.89 \pm 0.00$ \\
\hline & ${ }^{137}$ Cs & & & 1 & 1.08 \\
\hline \multirow[t]{4}{*}{ Food } & $40_{K}$ & & & 1 & 1.09 \\
\hline & ${ }^{90} \mathrm{Sr}$ & & & 1 & 1.02 \\
\hline & $131_{I}$ & & & 1 & 1.14 \\
\hline & ${ }^{137} \mathrm{Cs}$ & & & 1 & 1.15 \\
\hline
\end{tabular}

(a) Each sample is analyzed in triplicate.

(b) Average \pm standard deviation of the average. 
TABLE C.2. QA Data for 100 Area Airborne Release Dose Calculation

Facility name:

Releases:

Meteorological conditions:

Dispersion model:

$X / Q$ :

Release height:

Population distribution:

Computer code:

Calculated dose:

Files addressed:

Computer code:

Calculated dose:

Files addressed:

Computer code:

Calculated dose:

Files addressed:
100 Area

See Table 16

100-N meteorological tower 1-year data (2-70 through 1-71), annual average, see Table $D .1$

Gaussian, Hanf ord parameters

Maximum individual $2.7 \times 10^{-9} \mathrm{sec} / \mathrm{m}^{3}$ ?0 $\mathrm{km}$ SE-SEE

$80-\mathrm{km}$ population $4.1 \times 10^{-4}$ person $\cdot \mathrm{sec} / \mathrm{m}^{3}$

82.3 meters effective ( 60.96 meters actual stack height)

236,000 , see Figure D. 1

DACRIN, Rev. 3-31-78

Chronic inhalation, maximum individual and $80-\mathrm{km}$ population, first-year dose and 50-year dose commitment

Organ data library, Rev. 3-7-79

THERMA library, Rev. 10-29-75

F000, Rev. 8-1-78

Chronic ingestion and ground contamination exposure, maximum individual and 80-km population, first-year dose and 50-year dose comitment

Radionuc lide Library, Rev. 3-15-78

Food Transfer Library, Rev. 2-27-78

Organ Data Library, Rev. 9-8-78

Ground Dose Factor Library, Rev. 3-15-78

GRONK, Rev/8-5-75

Chronic air submersion, maximum individual and $80-\mathrm{km}$ population, first-year dose and 50-year dose commitment

DFEXT1, Rev. 11-17-77

TABLE C.3. QA Data for 100 Area Liquid Release Dose Calculation

\begin{tabular}{|c|c|}
\hline Facility name: & 100 Area \\
\hline River flow: & $117,200 \mathrm{cfs}$ \\
\hline Mixing ratio: & 1 \\
\hline Reconcentration formula: & 3 \\
\hline Shore-width factor: & 0.2 \\
\hline Population: & $\begin{array}{l}50,000--d r i n k i n g \text { water pathway } \\
125,000--f \text { ish and direct exposure }\end{array}$ \\
\hline Computer code: & ARRRG, Rev. $8-1-78$ \\
\hline Calculated dose: & $\begin{array}{l}\text { Chronic ingestion, direct exposure to water and shoreline, } \\
\text { maximum individual and } 80-\mathrm{km} \text { population, first-year dose } \\
\text { and } 50 \text {-year dose commitment }\end{array}$ \\
\hline Files addressed: & $\begin{array}{l}\text { Radionuclide Library, Rev. 3-15-78 } \\
\text { Organ Data Library, Rev. 9-8-78 } \\
\text { Hanford Specific Bio. Accum. Library } \\
\text { External Dose Factor Library, Rev. 3-15-78 }\end{array}$ \\
\hline
\end{tabular}




\section{TABLE C.4. QA Data for 200 Areas Airborne Release Dose Calculations}

\begin{tabular}{|c|c|}
\hline Facility name: & 200 Areas \\
\hline Meteorology conditions: & $\begin{array}{l}\text { HMS historical 15-year data (1955-1970), annual } \\
\text { average, see Jable } 0.2\end{array}$ \\
\hline Dispersion model: & Gaussian, Hanford parameters \\
\hline $\mathrm{X} / \mathrm{Q}:$ & $\begin{array}{l}\text { Maximum individual } 4.0 \times 10^{-9} \mathrm{sec} / \mathrm{m}^{3} \text { a } 37 \mathrm{~km} \mathrm{SE} \\
80-\mathrm{km} \text { population } 3.7 \times 10^{-4} \text { person. } \mathrm{sec} / \mathrm{m}^{3}\end{array}$ \\
\hline $\begin{array}{l}\text { Release height: } \\
\text { height) }\end{array}$ & 89.2 meters effective $\{60.96$ meters actual stack \\
\hline Population distribution: & 258,000 , see Figure 0.2 \\
\hline Computer code: & DACRIN, Rev. 3-31-78 \\
\hline Calculated dose: & $\begin{array}{l}\text { Chronic inhalation, maximum individual and } 80-\mathrm{km} \\
\text { population, first-year dose and } 50 \text {-year dose comitment }\end{array}$ \\
\hline Files addressed: & $\begin{array}{l}\text { Organ Data Library, Rev. } 3-7-79 \\
\text { IHERMA Library, Rev. 10-29-75 }\end{array}$ \\
\hline Computer code: & FOOD, Rev. $8-1-78$ \\
\hline Calculated dose: & $\begin{array}{l}\text { Chronic ingestion and ground contamination exposure, } \\
\text { maximum individual and } 80-\mathrm{km} \text { population, first- } \\
\text { year dose and } 50 \text {-year dose commitment }\end{array}$ \\
\hline Files addressed: & $\begin{array}{l}\text { Radionuclide Library, Rev. } 3-15-78 \\
\text { Food Transfer Library, Rev. } 2-27-79 \\
\text { Organ Data Library, Rev. } 9-8-78 \\
\text { Ground Dose Factor Library, Rev. } 3-15-79\end{array}$ \\
\hline Computer code: & GRONK, Rev. 8-5-75 \\
\hline Calculated dose: & $\begin{array}{l}\text { Chronic air submersion, maximum individual and } 80-\mathrm{km} \\
\text { population, first-year dose and } 50 \text {-year dose commitment }\end{array}$ \\
\hline Files addressed: & DFEXI1, Rev. 11-17-77 \\
\hline
\end{tabular}

TABLE C.5. QA Data for 300 Area Airborne Release Dose Calculations

Facility name:

Meteorology conditions:

Dispersion model:

$x / 0$ :

Release height:

Population distribution:

Computer code:

Calculated dose:

Files addressed:

Computer code:

Calculated dose:

Files addressed:

Computer code:

Calculated dose:

Files addressed:
300 Area

WPPSS 2-year data (4-74 through 3-76), annual average, see Table 0.3

Gaussian, Pasquill parameters

Maximum individual $2 \times 10^{-6} \mathrm{sec} / \mathrm{m}^{3}$ a $1.6 \mathrm{~km} \mathrm{E}$

$80-\mathrm{km}$ population $5.7 \times 10^{-3}$ person $\cdot \mathrm{sec} / \mathrm{m}^{3}$

Ground level

171,000 , see Figure 0.3

DACRIN, Rev. 3-31-78

Chronic inhalation, maximum individual and $80-\mathrm{km}$ population, first-year dose and 50-year dose commitment

Organ Data Library, Rev. 3-7-79 THERMA Library, Rev. 10-29-75

Fo0D, Rev. 8-1-78

Chronic ingestion and ground contamination exposure, maximum individual and $80-\mathrm{km}$ population, first-year dose and 50 -year dose commitment

Radionuc lide Library, Rev. 3-15-78

Food Iransfer Library, Rev, 2-27-78

Organ Data Library, Rev. 9-8-78

Ground Dose Factor Library, Rev. 3-15-78

GRONK, Rev. 8-5-75

Chronic air submersion, maximum individual and $80-\mathrm{km}$ population, first-year dose and 50-year dose cormitment DFExI1, Rev. 11-17-77 
APPENDIX D

RADIATION DOSE CALCULATIONS 


\section{RADIATION DOSE CALCULATIONS}

The methods used to compute environmental radiation doses from Hanford operations can be categorized as follows:

1. Whenever environmental monitoring data show the presence of radionuclides, the dose impact is calculated using standard techniques described in the text (e.g., the infant thyroid dose of $0.6 \mathrm{mrem}$ from fallout $131_{\text {I }}$ is calculated using methods of the Environmental Protection Agency, as described on page 16 of this report).

2. The liquid and gaseous radionuclide effluent released during the year by all Hanford facilities is included in the report. Since the quantities shown are generally undetectable in the environment, the dose impact is calculated using the effluent quantities as source terms and using theoretical dispersion, uptake, and dose models to compute the radiation dose. All of the models have been used previously to calculate doses from Hanford facilities and are considered to provide the best estimates of the generally undetectable dose impact attributable to Hanford operations.

Because the calculation of doses resulting from situations in Category 1 is infrequent and sufficient detail is included in the text in such cases, no supporting information is considered necessary here.

Category 2 dose calculations, because of the ir complex nature, require considerable supporting information, to which the balance of this appendix is devoted. In computing the overall impact of Hanford operations, each major operating area (100-N Area, 200 Areas, 300 Area) is considered separately. The distances between these areas result in differences in the population distribution, the meteorological conditions, and the location of the maximum offsite impact. The assumptions used to calculate the dose impact during 1978 were as follows:

\section{AIRBORNE EFFLUENTS}

Separate impacts were calculated for releases from the 100-N Area, the 200 Areas, and the 300 Area (see Table 16). The source term used for each area was the 1978 release from that area. Specific information on the meteorology, demography, and release height for each area is given below.

\section{$\underline{100-\mathrm{N} \text { Area }}$}

Gaseous effluent was released at an effective height of $82 \mathrm{~m}(269 \mathrm{ft})$ above ground level. The population distribution shown in Figure D.1 for the area within an $80-\mathrm{km}$ (50-mile) radius of the $100-N$ Area was used in the calculations. The annual average atmospheric dispersion data used are shown in Table 0.1 for the 100-N Area and are based on a year's worth of meteorological data collected several years ago (the only data available).

\section{Areas}

Gaseous effluent was assumed to be released at the center of the 200 Areas at an effective height of $89 \mathrm{~m}(292 \mathrm{ft})$ above ground level. Calculations used the population distribution shown in Figure 0.2 for the area within an $80-\mathrm{km}$ (50-mile) radius of the Hanford Meteorological Station (HMS) located on the east side of 200-West Area. Annual average atmospheric dispersion data used in the calculations are based on past meteorological data (the 15-yr average from 1955 to 1970) from HMS and are presented in Table D.2.

\section{Area}

Gaseous effluent was assumed to be released at ground level since most stacks in the 300 Area are rather short. Population distribution data shown in Figure 0.3 for the area within an $80-\mathrm{km}$ (50-mile) radius of the 300 Area were used in the calculations. Annual average atmospheric dispersion data developed from meteorological data collected by the Washington Public Power Supply System (a) for the WNP-2 reactor were used. These data are shown in Table D.3.

Doses were then calculated for exposure via the following sources:

- inhalation

- submersion

- ground deposition

- eating vegetables, fruits, etc., grown in the vicinity of Hanford

- eating meat and poultry products from animals raised in the vicinity of Hanford.

(a) We wish to thank WPPSS for permission to use the ir meteorological data. 


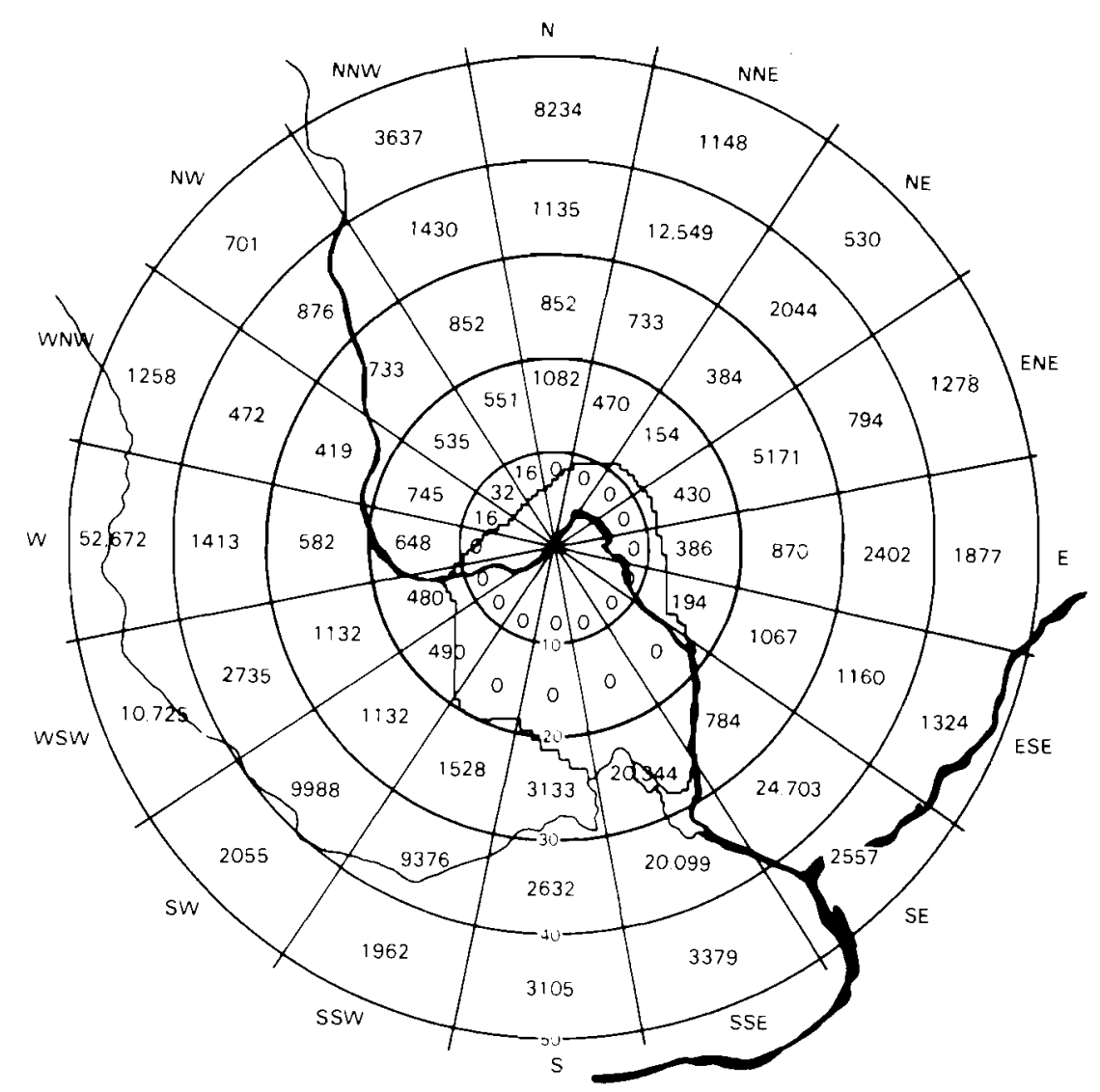

FIGURE D.1. Estimated Geographic Distribution of the Population $(236,000)$ Within a 50-Mile $(80-\mathrm{km})$ Radius of the $100-\mathrm{N}$ Area

TABLE D.1. Annual Average Atmospheric Dispersion Around the 100-N Area $\overline{\text { for an } 82}-\mathrm{m}$ Release Height (Units are $\mathrm{sec} / \mathrm{m}^{3}$ ) (a)

Range in Miles $(\mathrm{km})$

\begin{tabular}{|c|c|c|c|c|c|c|c|c|c|c|}
\hline \multirow[b]{2}{*}{ Direction } & \multicolumn{10}{|c|}{ Range in Miles $(\mathrm{km})$} \\
\hline & $0.5(0.8)$ & $1.5(2.4)$ & $2.5(4.0)$ & $3.5(5.6)$ & $4.5(7.2)$ & $7.5(2.0)$ & $15(24)$ & $25(40)$ & $35(56)$ & $45(72)$ \\
\hline $\begin{array}{l}\text { N } \\
\text { NNE } \\
\text { NE } \\
\text { ENE }\end{array}$ & $\begin{array}{l}3.68 \mathrm{E}-08 \\
5.24 \mathrm{E}-08 \\
1.44 \mathrm{E}-07 \\
1.21 \mathrm{E}-07\end{array}$ & $\begin{array}{l}1.60 E-08 \\
2.05 E-08 \\
4.84 E-08 \\
5.50 E-08\end{array}$ & $\begin{array}{l}9.02 E-09 \\
1.08 E-08 \\
2.35 E-08 \\
2.81 E-08\end{array}$ & $\begin{array}{l}5.69 E-09 \\
6.64 E-09 \\
1.39 E-08 \\
1.70 E-08\end{array}$ & $\begin{array}{l}4.05 E-09 \\
4.62 E-09 \\
9.39 E-09 \\
1.17 E-08\end{array}$ & $\begin{array}{l}2.49 \mathrm{E}-09 \\
2.68 \mathrm{E}-09 \\
5.02 \mathrm{E}-09 \\
6.65 \mathrm{E}-09\end{array}$ & $\begin{array}{l}1.91 E-09 \\
1.94 E-09 \\
3.30 E-09 \\
4.72 E-09\end{array}$ & $\begin{array}{l}1.44 \mathrm{E}-09 \\
1.46 \mathrm{E}-09 \\
2.44 \mathrm{E}-09 \\
3.56 \mathrm{E}-09\end{array}$ & $\begin{array}{l}1.10 \mathrm{E}-09 \\
1.12 \mathrm{E}-09 \\
1.87 \mathrm{E}-09 \\
2.73 \mathrm{E}-09\end{array}$ & $\begin{array}{l}8.69 E-10 \\
8.90 E-10 \\
1.48 E-09 \\
2.17 E-09\end{array}$ \\
\hline $\begin{array}{l}\text { E } \\
\text { ESE } \\
\text { SE } \\
\text { SSE }\end{array}$ & $\begin{array}{l}1.14 E-07 \\
1.20 E-07 \\
7.91 E-08 \\
7.94 E-08\end{array}$ & $\begin{array}{l}6.79 E-08 \\
7.12 E-08 \\
4.84 E-08 \\
4.40 E-08\end{array}$ & $\begin{array}{l}3.60 E-08 \\
3.76 E-08 \\
2.60 E-08 \\
2.27 E-08\end{array}$ & $\begin{array}{l}2.20 E-08 \\
2.29 E-08 \\
1.60 E-08 \\
1.37 E-08\end{array}$ & $\begin{array}{l}E-08 \\
E-08 \\
E-08 \\
E-09\end{array}$ & $\begin{array}{l}E-09 \\
E-09 \\
E-09 \\
E-09\end{array}$ & $\begin{array}{l}7.43 E-09 \\
6.87 E-09 \\
3.81 E-09 \\
2.72 E-09\end{array}$ & $\begin{array}{l}5.95 \mathrm{E}-09 \\
5.41 \mathrm{E}-09 \\
2.74 \mathrm{E}-09 \\
1.85 \mathrm{E}-09\end{array}$ & $\begin{array}{l}4.70 E-09 \\
4.27 E-09 \\
2.07 E-09 \\
1.36 E-09\end{array}$ & $\begin{array}{l}3.79 E-09 \\
3.45 E-09 \\
1.63 E-09 \\
1.05 E-09\end{array}$ \\
\hline $\begin{array}{l}\text { SSW } \\
\text { SW } \\
\text { WSW }\end{array}$ & $\begin{array}{l}9.41 \mathrm{E}-08 \\
1.61 \mathrm{E}-07 \\
7.78 \mathrm{E}-08 \\
5.39 \mathrm{E}-08\end{array}$ & $\begin{array}{l}4.26 E-08 \\
5.84 E-08 \\
3.33 E-08 \\
2.74 E-08\end{array}$ & $\begin{array}{l}2.14 E-08 \\
2.82 E-08 \\
1.77 E-08 \\
1.62 E-08\end{array}$ & $\begin{array}{l}1.27 E-08 \\
1.65 E-08 \\
1.08 E-08 \\
1.04 E-08\end{array}$ & $\begin{array}{l}8.58 E-09 \\
1.10 E-08 \\
7.49 E-09 \\
7.39 E-09\end{array}$ & $\begin{array}{l}4.25 E-09 \\
5.38 E-09 \\
4.13 E-09 \\
4.34 E-09\end{array}$ & $\begin{array}{l}2.32 E-09 \\
2.89 E-09 \\
2.67 E-09 \\
2.99 E-09\end{array}$ & $\begin{array}{ll}9 & 1.55 E-09 \\
9 & 1.93 E-09 \\
9 & 1.89 E-09 \\
9 & 2.14 E-09\end{array}$ & $\begin{array}{l}1.13 \mathrm{E}-09 \\
1.41 \mathrm{E}-09 \\
1.41 \mathrm{E}-09 \\
1.59 \mathrm{E}-09\end{array}$ & $\begin{array}{l}8.70 E-10 \\
1.09 E-09 \\
1.10 E-09 \\
1.24 E-09\end{array}$ \\
\hline $\begin{array}{l}W \\
W N W \\
N W \\
\text { NNW }\end{array}$ & $\begin{array}{l}7.20 \mathrm{E}-08 \\
8.53 \mathrm{E}-08 \\
8.32 \mathrm{E}-08 \\
4.68 \mathrm{E}-08\end{array}$ & $\begin{array}{l}3.48 E-08 \\
3.75 E-08 \\
3.48 E-08 \\
2.07 E-08\end{array}$ & $\begin{array}{l}1.97 E-08 \\
2.07 E-08 \\
1.90 E-08 \\
1.18 E-08\end{array}$ & $\begin{array}{l}1.25 E-08 \\
1.29 E-08 \\
1.18 E-08 \\
7.43 E-09\end{array}$ & $\begin{array}{l}8.81 E-09 \\
9.02 E-09 \\
8.24 E-09 \\
5.22 E-09\end{array}$ & $\begin{array}{l}5.20 E-09 \\
5.09 E-09 \\
4.62 E-09 \\
2.99 E-09\end{array}$ & $\begin{array}{l}3.64 E-09 \\
3.39 E-09 \\
3.60 E-09 \\
2.04 E-09\end{array}$ & $\begin{array}{ll}9 & 2.62 E-09 \\
9 & 2.41 E-09 \\
9 & 2.19 E-09 \\
9 & 1.48 E-09\end{array}$ & $\begin{array}{l}1.95 E-09 \\
1.80 E-09 \\
1.64 E-09 \\
1.11 E-09\end{array}$ & $\begin{array}{l}1.52 E-09 \\
1.40 E-09 \\
1.28 E-09 \\
8.69 E-10\end{array}$ \\
\hline
\end{tabular}

(a) Calculated from meteorological data collected for the period 2-70 through 1-71. 


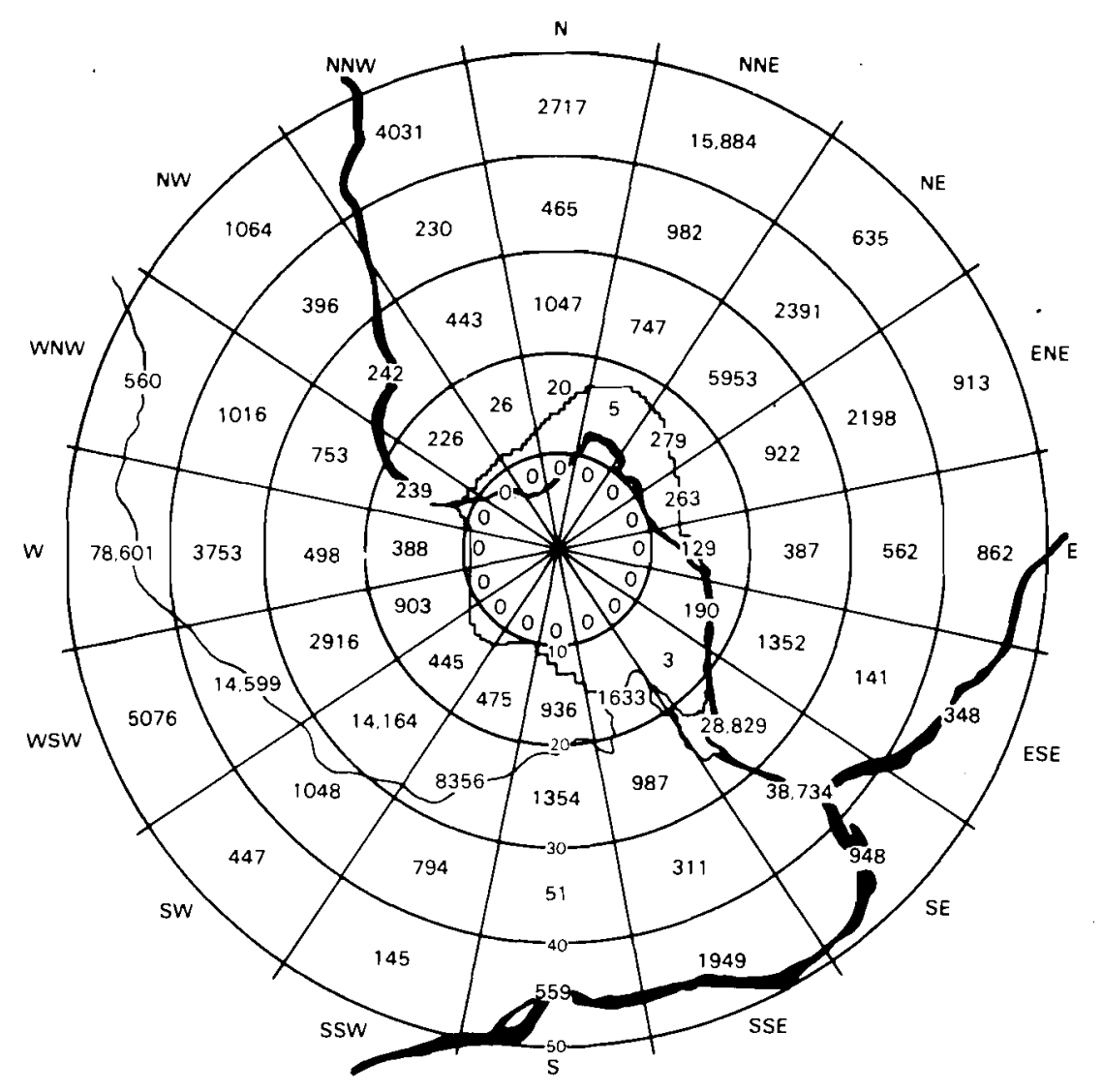

FIGURE D.2. Estimated Geographic Distribution of the Population $(258,000)$ Within a $50-M i l e(80-\mathrm{km})$ Radius of the Hanford Meteorological Station

TABLE D.2. Annual Average Atmospheric Dispersion Around the 200 Areas

for an $89-\mathrm{m}$ Release Height (Units are $\mathrm{sec} / \mathrm{m}^{3}$ ) $(\mathrm{a}$ )

\begin{tabular}{|c|c|c|c|c|c|c|c|c|c|c|}
\hline \multirow[b]{2}{*}{ Direction } & \multicolumn{10}{|c|}{ Range in Miles $(\mathrm{km})$} \\
\hline & $0.5(0.8)$ & $1.5(2.4)$ & $2.5(4.0)$ & $3.5(5.6)$ & $4.5(7.2)$ & $7.5(12.0)$ & $15(24)$ & $25(40)$ & $35(56)$ & $45(72)$ \\
\hline N & $3.29 E-08$ & $1.76 \mathrm{E}-08$ & $1.04 \mathrm{E}-08$ & $6.91 E-09$ & $37 E-09$ & $2.29 E-09$ & $18 \mathrm{E}$ & $7.81 \mathrm{E}-$ & $6.23 \mathrm{E}-10$ & $5.10 \mathrm{E}-$ \\
\hline NNE & $4.70 E-08$ & $1.90 \mathrm{E}-08$ & $1.05 \mathrm{E}-08$ & $6.82 \mathrm{E}-09$ & $76 \mathrm{E}-09$ & $2.22 \mathrm{E}-09$ & 09 & $E-10$ & 6.60 & $5.47 \mathrm{E}$ \\
\hline NE & 8.05 & 3. $02 E-08$ & 1 & $E-09$ & $E-09$ & 09 & 09 & 1. & 10 & $8.26 \mathrm{E}$ \\
\hline ENE & 7.6 & $2.84 \mathrm{E}-08$ & 1.4 & $E-09$ & $E-09$ & & & 1.3 & 1 . & $9.64 \mathrm{E}$ \\
\hline Eco & 4. $61 \mathrm{E}-08$ & $2.28 E-08$ & 1. $32 \mathrm{E}-08$ & $8.72 \mathrm{E}-09$ & $7 E-09$ & $3.18 \mathrm{E}-09$ & 09 & 09 & & $.39 \mathrm{E}-09$ \\
\hline r. & 7.9 & 4.00 & & & & & & & & $.50 \mathrm{E}-09$ \\
\hline $\begin{array}{l}S E \\
S S E\end{array}$ & $1.67 \mathrm{E}-07$ & 7. $60 \mathrm{E}-08$ & 4. $02 \mathrm{E}-08$ & -08 & $E-08$ & 7.97E-09 & $4.54 E-09$ & $3.73 E-09$ & $3.12 \mathrm{E}-09$ & $2.62 \mathrm{E}-09$ \\
\hline & & & & & & & & & & \\
\hline 3 & -08 & $4.38 E-08$ & $2.55 \mathrm{E}-08$ & $1.68 \mathrm{E}-08$ & $1.18 \mathrm{E}$ & 5.408 & $2.14 \mathrm{E}-09$ & $1.33 \mathrm{E}-09$ & -10 & 7.71 \\
\hline sst & 7. & 3.8 & 2.1 & $E-08$ & 9.8 & 4.4 & 1 . & 9. & 10 & 5.3 \\
\hline SW & $6.89 E-08$ & $4.06 \mathrm{E}-08$ & 2. $36 \mathrm{E}-08$ & $1.54 \mathrm{E}-08$ & $1.08 \mathrm{E}-08$ & $4.82 E-09$ & $1.73 E-09$ & $9.64 E-10$ & $6.79 \mathrm{E}-10$ & $5.19 \mathrm{E}-10$ \\
\hline WSW & $3.74 \mathrm{E}$ & $2.39 E-08$ & $110 \mathrm{C}$ & $1.01 \mathrm{E}-08$ & 7.2 & $3.30 \mathrm{E}-09$ & $1.24 \mathrm{E}-09$ & 10 & $518 \mathrm{E}-10$ & 4.02E-10 \\
\hline $\mathbf{W}$ & $3.72 \mathrm{E}-08$ & $2.57 \mathrm{E}-08$ & 1. & $1.13 E-08$ & 8.1 & 3.76 & $1.44 \mathrm{E}$ & 10 & -10 & 4. \\
\hline WNW & & -08 & & 1.1 & 8.0 & & 1.63 & 1.0 & $8.20 \mathrm{E}-10$ & $6.56 \mathrm{E}-10$ \\
\hline NW & $4.17 \mathrm{E}-08$ & 2. $69 \mathrm{E}-08$ & $1.82 \mathrm{E}-08$ & $1.29 E-08$ & $9.41 \mathrm{E}-09$ & $4.55 E-09$ & $2.08 \mathrm{E}-09$ & $1.45 \mathrm{E}-09$ & $1.13 E-09$ & $9.10 \mathrm{E}-10$ \\
\hline NNV & 2.68 & $E-08$ & $1.03 \mathrm{E}-08$ & $7.27 \mathrm{E}-09$ & $5.27 \mathrm{E}-09$ & $2.56 \mathrm{E}-09$ & $1.22 \mathrm{E}-09$ & $8.79 E-10$ & $6.94 \mathrm{E}-10$ & $5.64 \mathrm{E}-10$ \\
\hline
\end{tabular}

(a) Calculated from meteorological data collected from 1955 through 1970. 


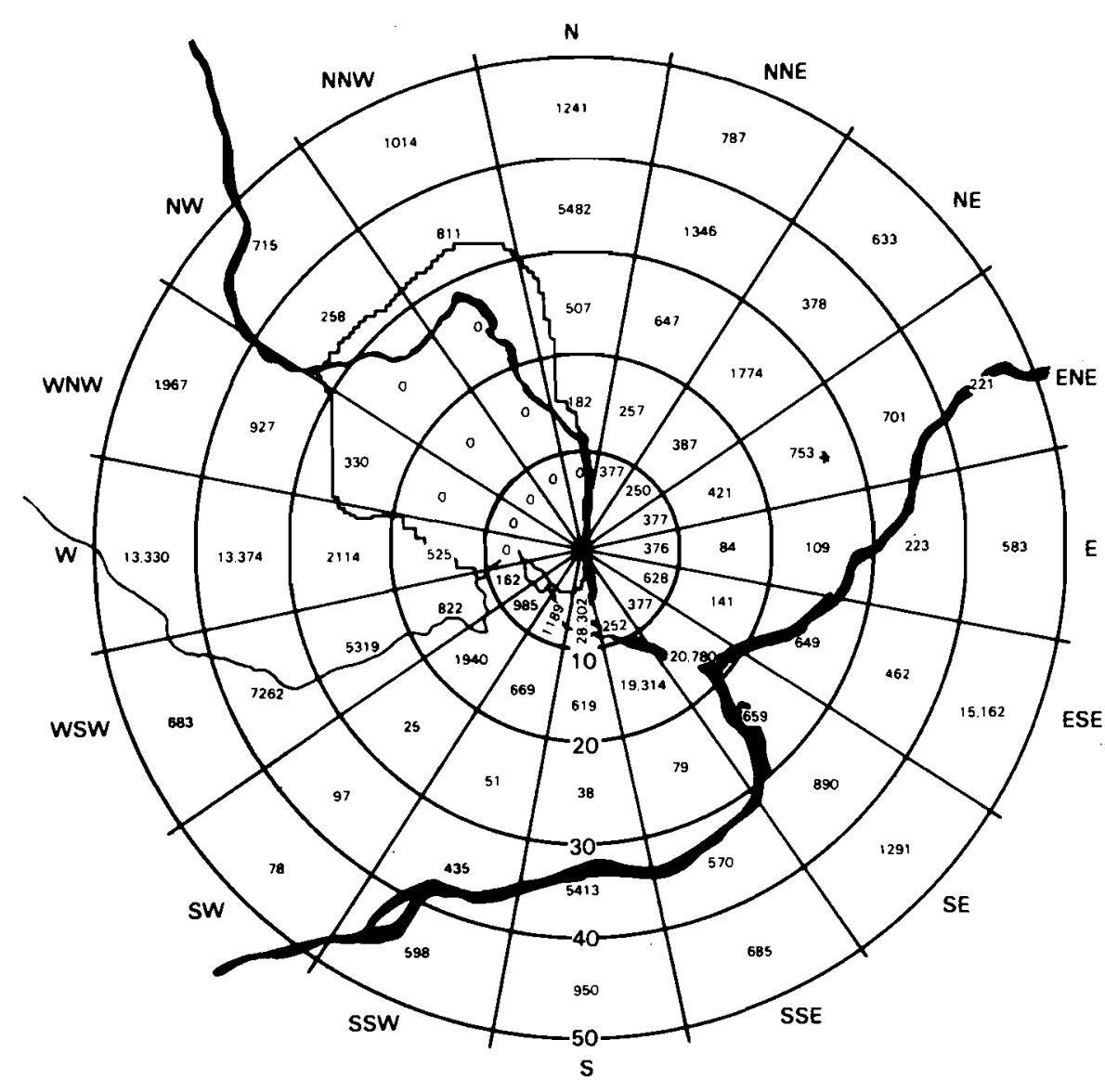

FIGURE D.3. Estimated Geographic Distribution of the Population $(171,000)$ Within a 50-Mile $(80-\mathrm{km})$ Radius of the 300 Areas

TABLE D.3. Annual Average Atmospheric Dispersion Around the 300 Area for a Ground-Level Release (Units are $\mathrm{sec} / \mathrm{m}^{3}$ ) $(\mathrm{a})$

\begin{tabular}{|c|c|c|c|c|c|c|c|c|c|c|}
\hline & & & & & 0 & iles (km) & & & & \\
\hline Direction & $0.5(0.8)$ & $1.5(2.4)$ & $2.5(4.0)$ & $3.5(5.6)$ & $4.5(7.2)$ & $7.5(12.0)$ & $15(24)$ & $25(40)$ & $35(56)$ & $45(72)$ \\
\hline $\begin{array}{l}\text { N } \\
\text { NNE } \\
\text { NE } \\
\text { ENE }\end{array}$ & $\begin{array}{l}5.7 E-06 \\
5.0 E-06 \\
3.9 E-06 \\
3.6 E-06\end{array}$ & $\begin{array}{l}8.7 \mathrm{E}-07 \\
7.6 \mathrm{E}-07 \\
5.9 \mathrm{E}-07 \\
5.5 \mathrm{E}-07\end{array}$ & $\begin{array}{l}3.9 E-07 \\
3.4 E-07 \\
2.6 E-07 \\
2.5 E-07\end{array}$ & $\begin{array}{l}2.4 \mathrm{E}-07 \\
2.1 \mathrm{E}-07 \\
1.6 \mathrm{E}-07 \\
1.5 \mathrm{E}-07\end{array}$ & $\begin{array}{l}1.6 \mathrm{E}-07 \\
1.4 \mathrm{E}-07 \\
1.1 \mathrm{E}-07 \\
1.0 \mathrm{E}-07\end{array}$ & $\begin{array}{l}7.9 \mathrm{E}-08 \\
6.9 \mathrm{E}-08 \\
5.3 \mathrm{E}-08 \\
5.0 \mathrm{E}-08\end{array}$ & $\begin{array}{l}3.1 \mathrm{E}-08 \\
2.7 \mathrm{E}-08 \\
2.1 \mathrm{E}-08 \\
1.9 \mathrm{E}-08\end{array}$ & $\begin{array}{l}1.6 \mathrm{E}-08 \\
1.3 \mathrm{E}-08 \\
1.0 \mathrm{E}-08 \\
9.8 \mathrm{E}-09\end{array}$ & $\begin{array}{l}1.0 E-08 \\
8.7 E-09 \\
6.7 E-09 \\
6.4 E-09\end{array}$ & $\begin{array}{l}7.4 \mathrm{E}-09 \\
6.3 \mathrm{E}-09 \\
4.9 \mathrm{E}-09 \\
4.6 \mathrm{E}-09\end{array}$ \\
\hline $\begin{array}{l}\text { E } \\
\text { ESE } \\
\text { SE } \\
\text { SSE }\end{array}$ & $\begin{array}{l}3.4 \mathrm{E}-06 \\
5.8 \mathrm{E}-06 \\
7.2 \mathrm{E}-06 \\
7.2 \mathrm{E}-06\end{array}$ & $\begin{array}{l}5.1 \mathrm{E}-07 \\
8.8 \mathrm{E}-07 \\
1.1 \mathrm{E}-06 \\
1.1 \mathrm{E}-06\end{array}$ & $\begin{array}{l}\text { 2. } 3 \mathrm{E}-07 \\
4.0 \mathrm{E}-07 \\
4.9 \mathrm{E}-07 \\
4.7 \mathrm{E}-07\end{array}$ & $\begin{array}{l}1.4 \mathrm{E}-07 \\
2.4 \mathrm{E}-07 \\
3.0 \mathrm{E}-07 \\
2.9 \mathrm{E}-07\end{array}$ & $\begin{array}{l}9.4 \mathrm{E}-08 \\
1.7 \mathrm{E}-07 \\
2.1 \mathrm{E}-07 \\
2.0 \mathrm{E}-07\end{array}$ & $\begin{array}{l}\text { 4. } 6 \mathrm{E}-08 \\
8.0 \mathrm{E}-08 \\
1.0 \mathrm{E}-07 \\
9.6 \mathrm{E}-08\end{array}$ & $\begin{array}{l}1.8 \mathrm{E}-08 \\
3.1 \mathrm{E}-08 \\
3.9 \mathrm{E}-08 \\
3.8 \mathrm{E}-08\end{array}$ & $\begin{array}{l}9.0 \mathrm{E}-09 \\
1.6 \mathrm{E}-08 \\
2.0 \mathrm{E}-08 \\
1.9 \mathrm{E}-08\end{array}$ & $\begin{array}{l}5.9 \mathrm{E}-09 \\
1.0 \mathrm{E}-08 \\
1.3 \mathrm{E}-08 \\
1.2 \mathrm{E}-08\end{array}$ & $\begin{array}{l}\text { 4. 3E-09 } \\
\text { 7. } 5 \mathrm{E}-09 \\
9.3 \mathrm{E}-09 \\
9.0 \mathrm{E}-09\end{array}$ \\
\hline $\begin{array}{l}\text { S } \\
\text { SSW } \\
\text { SW } \\
\text { WSW }\end{array}$ & $\begin{array}{l}5.5 \mathrm{E}-06 \\
4.4 \mathrm{E}-06 \\
3.8 \mathrm{E}-06 \\
3.0 \mathrm{E}-06\end{array}$ & $\begin{array}{l}8.4 \mathrm{E}-07 \\
6.8 \mathrm{E}-07 \\
5.9 \mathrm{E}-07 \\
4.6 \mathrm{E}-07\end{array}$ & $\begin{array}{l}3.8 \mathrm{E}-07 \\
3.1 \mathrm{E}-07 \\
2.7 \mathrm{E}-07 \\
2.1 \mathrm{E}-07\end{array}$ & $\begin{array}{l}2.4 \mathrm{E}-07 \\
1.9 \mathrm{E}-07 \\
1.7 \mathrm{E}-07 \\
1.3 \mathrm{E}-07\end{array}$ & $\begin{array}{l}1.6 \mathrm{E}-07 \\
1.3 \mathrm{E}-07 \\
1.1 \mathrm{E}-07 \\
8.8 \mathrm{E}-08\end{array}$ & $\begin{array}{l}7.8 E-08 \\
6.3 E-08 \\
5.5 E-08 \\
4.3 E-08\end{array}$ & $\begin{array}{l}3.0 \mathrm{E}-08 \\
2.5 \mathrm{E}-08 \\
2.2 \mathrm{E}-08 \\
1.7 \mathrm{E}-08\end{array}$ & $\begin{array}{l}1.5 \mathrm{E}-08 \\
1.3 \mathrm{E}-08 \\
1.1 \mathrm{E}-08 \\
8.5 \mathrm{E}-09\end{array}$ & $\begin{array}{l}1.0 \mathrm{E}-08 \\
8.2 \mathrm{E}-09 \\
7.2 \mathrm{E}-09 \\
5.6 \mathrm{E}-09\end{array}$ & $\begin{array}{l}\text { 7. } 3 \mathrm{E}-09 \\
6.0 \mathrm{E}-09 \\
5.2 \mathrm{E}-09 \\
4.0 \mathrm{E}-09\end{array}$ \\
\hline $\begin{array}{l}W \\
\text { WNW } \\
\text { MW } \\
\text { NNW }\end{array}$ & $\begin{array}{l}2.6 \mathrm{E}-06 \\
2.9 \mathrm{E}-06 \\
3.6 \mathrm{E}-06 \\
5.4 \mathrm{E}-06\end{array}$ & $\begin{array}{l}4.1 E-07 \\
4.4 E-07 \\
5.4 E-07 \\
8.2 E-07\end{array}$ & $\begin{array}{l}1.8 \mathrm{E}-07 \\
2.0 \mathrm{E}-07 \\
2.4 \mathrm{E}-07 \\
3.7 \mathrm{E}-07\end{array}$ & $\begin{array}{l}1.2 \mathrm{E}-07 \\
1.2 \mathrm{E}-07 \\
1.5 \mathrm{E}-07 \\
2.2 \mathrm{E}-07\end{array}$ & $\begin{array}{l}7.8 E-08 \\
8.2 E-08 \\
1.0 E-07 \\
1.5 E-07\end{array}$ & $\begin{array}{l}\text { 3. } 8 \mathrm{E}-08 \\
\text { 4. } 0 \mathrm{E}-0 \mathrm{~B} \\
\text { 4. } 9 \mathrm{E}-0 \mathrm{~B} \\
\text { 7. } 4 \mathrm{E}-08\end{array}$ & $\begin{array}{l}1.5 E-08 \\
1.5 E-08 \\
1.9 E-08 \\
2.9 E-08\end{array}$ & $\begin{array}{l}7.5 \mathrm{E}-09 \\
7.8 \mathrm{E}-09 \\
9.5 \mathrm{E}-09 \\
1.5 \mathrm{E}-08\end{array}$ & $\begin{array}{l}4.9 \mathrm{E}-09 \\
5.1 \mathrm{E}-09 \\
6.2 \mathrm{E}-09 \\
9.5 \mathrm{E}-09\end{array}$ & $\begin{array}{l}3.6 \mathrm{E}-09 \\
3.7 \mathrm{E}-09 \\
4.5 \mathrm{E}-09 \\
6.9 \mathrm{E}-09\end{array}$ \\
\hline
\end{tabular}

(a) Calculated from meteorological data collected during the period 4-74 through 3-76. 


\section{LIQUID EFFLUENTS}

The 1978 releases, shown in Table 16 in the text, were assumed to be mixed with the total annual flow of the Columbia River. For 1978, the United States Geological Survey reported that the mean annual flow rate was 117,200 cubic feet per second.

Doses were then calculated for intakes or exposure via the following sources:

- drinking sanitary water obtained from the river

- eating fish obtained from the river

- eating vegetables, fruits, etc., grown using river water for irrigation

- eating meat and poultry products from animals fed on irrigated pasture
- swimming, boating, or recreating on the shoreline.

\section{DIETARY ASSUMPTIONS}

All calculations were made using the models described in References 13 and 14 . The transfer and bioaccumulation factors are too numerous to be presented here but can be obtained from the references. Data on the consumption of the various foodstuffs considered in computing both the hypothetical maximum individual and the population doses are summarized in Tables 0.4 and 0.5 . The values shown in Table 0.4 are also used to estimate the ingestion and external dose resulting from deposition of radionuclides released to the atmosphere.

TABLE D.4. Foodstuff Holdup and Consumption

\begin{tabular}{|c|c|c|c|c|}
\hline \multirow[b]{2}{*}{ Foodstuff } & \multirow{2}{*}{$\begin{array}{l}\text { Maximum } \\
\text { Individyal } \\
\text { Holdup (a) } \\
\text { (Days) } \\
\end{array}$} & \multicolumn{2}{|c|}{$\begin{array}{l}\text { Consumption (in } \\
\mathrm{kg} / \mathrm{yr} \text { except as } \\
\text { otherwise noted) }\end{array}$} & \multirow{2}{*}{$\begin{array}{c}\text { Populat jon } \\
\text { Holdupla) } \\
\text { (Days) } \\
\end{array}$} \\
\hline & & $\begin{array}{l}\text { Maximum } \\
\text { Individual } \\
\end{array}$ & Population & \\
\hline Leafy vegetables & 1.0 & 30 & 15 & 14 \\
\hline O.A.G. ${ }^{\text {(b) }}$ vegetables & 1.0 & 30 & 15 & 14 \\
\hline Potatoes & 10.0 & 110 & 100 & 14 \\
\hline Other root vegetables & 1.0 & 72 & 17 & 14 \\
\hline Berries & 1.0 & 30 & 6 & 14 \\
\hline Melons & 1.0 & 40 & 8 & 14 \\
\hline Orchard fruit & 10.0 & 265 & 50 & 14 \\
\hline Wheat & 10.0 & 80 & 72 & 14 \\
\hline Other grain & 1.0 & 8.3 & 7.5 & 14 \\
\hline Eggs & 1.0 & 30 & 20 & 18 \\
\hline Milk & . 1.0 & $274 \ell / y r$ & $230 \ell / y r$ & 4 \\
\hline Beef & 15.0 & 40 & 40 & 34 \\
\hline Pork & 15.0 & 40 & 30 & 34 \\
\hline Poultry & 1.0 & 18 & 8.5 & 34 \\
\hline Ground contamination & 0 & $4388 \mathrm{hr} / \mathrm{yr}$ & $1461 \mathrm{hr} / \mathrm{yr}$ & 0 \\
\hline Inhalation & 0 & $7300 \mathrm{~m}^{3} / \mathrm{yr}$ & $7300 \mathrm{~m}^{3} / \mathrm{yr}$ & 0 \\
\hline
\end{tabular}

(a) Holdup is the decay time between harvest and consumption.

(b) Other above-ground. 
TABLE D.5. Consumption and Usage Factors for Calculation of Exposures from the Columbia River

\begin{tabular}{|c|c|c|c|}
\hline \multirow[b]{2}{*}{ Exposure Mode } & \multirow[b]{2}{*}{$\begin{array}{l}\text { Holdup (a) } \\
\text { Hours }\end{array}$} & \multicolumn{2}{|c|}{ Usage } \\
\hline & & $\begin{array}{l}\text { Maximum } \\
\text { Individual } \\
\end{array}$ & Population \\
\hline Fish & 24 & $40 \mathrm{~kg} / \mathrm{yr}$ & $15,000 \mathrm{~kg} / \mathrm{yr}(\mathrm{b})$ \\
\hline Drinking Water & 24 & $730 \ell / y r$ & $438 \ell / y r$ \\
\hline Shoreline & $8(c)$ & $500 \mathrm{hr} / \mathrm{yr}$ & $17 \mathrm{hr} / \mathrm{yr}$ \\
\hline Swimming & $8(c)$ & $100 \mathrm{hr} / \mathrm{yr}$ & $10 \mathrm{hr} / \mathrm{yr}$ \\
\hline Boating & $8(c)$ & $100 \mathrm{hr} / \mathrm{yr}$ & $5 \mathrm{hr} / \mathrm{yr}$ \\
\hline
\end{tabular}

(a) Holdup is the decay time between harvest and consumption or between effluent release and exposure.

(b) The population dose is based on the consumption of $15,000 \mathrm{~kg}$ of fish and would be numerically the same regardless of the number of people eating the fish.

(c) A 13-hour holdup time was assumed for the population dose calculations. 
No. of

Copies

\section{OFFSITE}

A. A. Churm

DOE Patent Division

9800 South Cass Avenue

Argonne, IL 60439

W. W. Burr, Jr.

DOE Office of Health and

Environmental Research

Washington, DC 20545

R. H. Engleken

NRC Directorate of Regional

Operations, Region V

1990 N. California Blvd., Suite 202

Walnut Creek, CA 94596

258 DOE Technical Information Center

R. J. Beers

DOE Idaho Operations

Operational Safety Division

Idaho Falls, ID 83401

5 W. M. McCool

DOE Operational and Environmental

Safety Division

Washington, DC 20545

A. A. Schoen

DOE Operational and Environmental Safety Division

Washington, DC 20545

S. R. Elliot

DOE Nevada Operations Office

Office of Safety and Health

P.0. Box 14100

Las Vegas, NV 89114

E. Cowan

Environmental Protection Agency Region $X$

Seattle, WA 98101

L. B. Day, Director

Oregon State Department of

Environmental Quality

1234 S. W. Morrison

Portland, OR 97205

M. W. Parratt

Oregon State Health Division

P.0. Box 231

Portland, OR 97207
R. R. Mooney

Washington State Department of Social and Health Services

1514 Smith Tower

Seatt le, WA 98104

W. F. Miller

Washington State Department of Social and Health Services

P. 0. Box 1788, MS 56-1

Olympia, WA 98504

S. I. Reed

Washington State Department of Social and Health Services

P.0. Box 1788, MS 56-1

Olympia, WA 98504

T. Strong

Washington State Department of Social and Health Services

P. 0. Box 1788 , MS 56-1

Olympia, WA 98504

R. C. Will

Washington State Department of Social and Health Services

P.0. Box 1788, MS 56-1

Olympia, WA 98504

W. G. Hallauer

Washington State Department of 'Ecology

01 ymp ia, WA 98504

G. Hansen

Washington State Department of Ecology

Olympia, WA 98504

E. Wallace

Washington State Department of Ecology

Olympia, WA 98504

Health Officer

Yakima County Health District

City Hall

Yakima, WA 98901

H. Cahn

Benton-Frank Iin Health Center

Pasco, WA 99301 
R. A. Chitwood

Washington Public Power

Supply System

3000 George Washington Way

Richland, WA 99352

R. K. Woodruff

Washington Public Power

Supply System

3000 George Washington Way

Richland, WA 99352

K. R. Engstrom

City of Rich land

Water and Sewer Department

505 Swift Boulevard

Rich 1 and, WA 99352

M. L. Smith

Exxon Nuc lear

Horn Rapids Road

Richland, WA 99352

\section{ONSITE}

19 DOE RICHLAND OPERATIONS OFFICE

D. R. Elle (14)

0 . J. Elgert

L. F. Perkins

H. E. Ransom

M. W. Tiernan

M. G. White

6 UNC Nuc lear, Inc.

T. E. Dabrowski

L. P. Diediker

J. J. Dorian

R. E. Dun

N. R. Miller

UNI Files

5 Rockwe11 Hanford Operations

G. L. Hanson

W. F. Heine

J. V. Panesko

R. E. Wheeler

RHO Files

2 Hanford Environmental Health Foundation

B. D. Reinert

B. D. Breitenstein
3 U. S. Testing Company, Inc.

W. V. Baumgartner

M. M. Lardy

H. E. Oens

3 Westinghouse Hanford Company

H. Bicehouse

R. 0. Budd

R. B. Ha11

114 Pacific Northwest Laboratory

J. L. Baer

W. J. Bair

P. J. Blumer

P. E. Bramson

F. P. Brauer

L. A. Carter

J. P. Corley

C. E. Cushing

P. A. Eddy

J. R. Eliason

D. L. Haggard

J. R. Houston (64)

R. F. Foster

J. J. Fuquay

W. T. Hinds

G. R. Hoenes

J. J. Jech

H. V. Larson

W. D. McCormack

D. A. Myers

J. M. Nielsen

D. E. Olesen

H. M. Parker

E. H. Phinney

R. W. Perkins

K. R. Price

M. R. Quarders (6)

W. H. Rickard

W. D. Richmond

D. B. Robertson

D. E. Robertson

J. M. Selby

C. L. Simpson

J. R. Sletager

J. H. Soehnlein

J. K. Soldat

C. M. Unruh

B. E. Vaughan

D. G. Watson

Technical Information (5)

Publishing Coordination (2) Go

1 J. A. Jones Construction Company

L. L. Crass 